\title{
Vezető polimereken alapuló fotokatalitikus hatású összetett elektródok előállítása, jellemzése és lehetséges alkalmazásai
}

\author{
Doktori (Ph.D.) értekezés
}

\author{
Bencsik Gábor \\ okleveles vegyész
}

Témavezetö:

Dr. Visy Csaba

egyetemi tanár

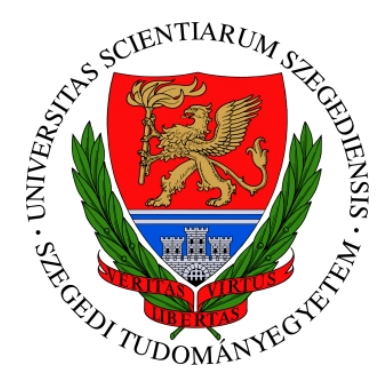

Kémia Doktori Iskola

Fizikai Kémiai és Anyagtudományi Tanszék

SzTE TTIK

2012

Szeged 


\section{Rövidítések jegyzéke}

EDX Energiadiszperzív röntgen spektroszkópia

EQCM Elektrokémiai kvarckristály mikromérleg

ITO Indium-ón-oxid

PANI Polianilin

PEDOT Poli(3,4-etilén-dioxi-tiofén)

POT Poli(3-oktil-tiofén)

PPy Polipirrol

PTO Kálium-tetraoxalát

SHE Standard hidrogénelektród

SDS Nátrium-dodecil-szulfát

SEM Pásztázó elektronmikroszkópia

UV-Vis Ultraibolya-látható

XRD Röntgendiffrakció 


\section{Tartalomjegyzék}

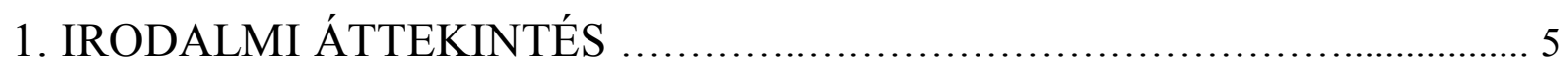

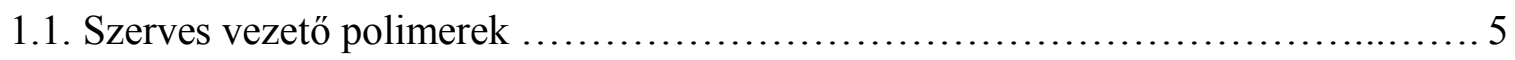

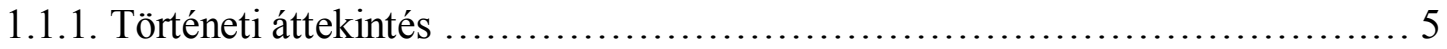

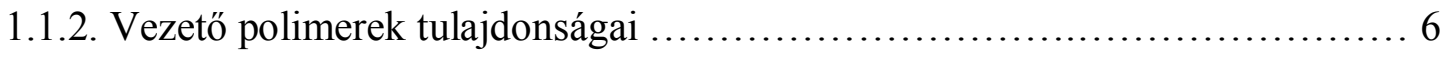

1.1.3. Vezető polimerek elóállítása ….......................................... 7

1.2. Vezetö polimer alapú nanokompozitok ...................................... 7

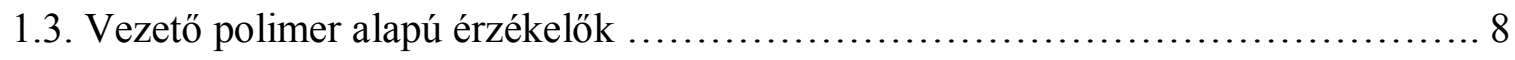

1.4. Vezetô polimerek fotokémiai tulajdonságai ........................................ 10

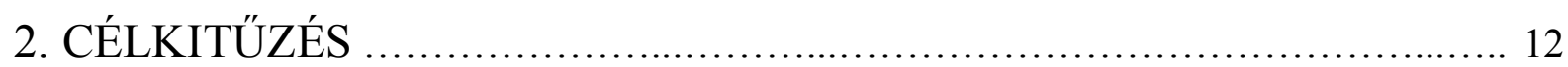

3. FELHASZNÁLT ANYAGOK, MÜSZEREK ÉS MÓDSZEREK .............. 13

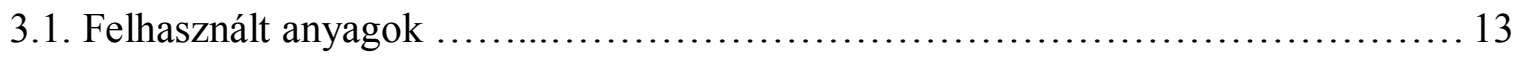

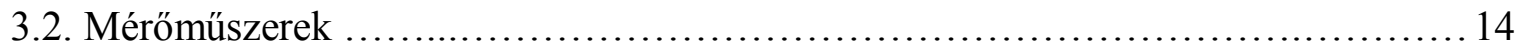

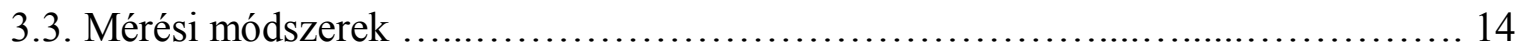

4. EREDMÉNYEK ÉS ÉRTÉKELÉSÜK …................................. 16

4.1. POT/vas-oxalát és PPy/vas-oxalát kompozitok kémiai előállítása és vizsgálata ......16

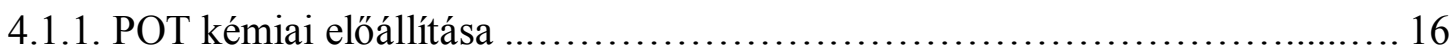

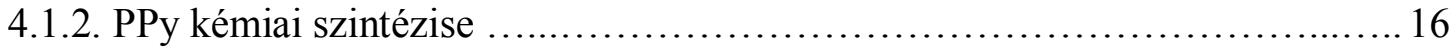

4.1.3. POT és PPy alapú vas-oxalát kompozitok kémiai elóállítása .................... 17

4.1.4. A kompozitok anyagszerkezetének vizsgálata ................................. 17

4.2. PPy/vas-oxalát filmek elektrokémiai elöállítása és jellemzése ............................ 19

4.2.1. PPy/vas-oxalát filmek elektrokémiai elóállitása ................................. 19

4.2.2. PPy filmek elektrokémiai viselkedése ….................................... 19

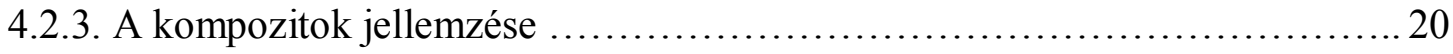

4.2.3.1. Pásztázó elektronmikroszkópiás és elemanalitikai vizsgálatok ........... 20

4.2.3.2. A PPy/vas-oxalát film EQCM vizsgálata .................................22

4.2.3.3. Mössbauer-spektroszkópiás vizsgálatok ................................. 24

4.2.3.4. A PPy/vas-oxalát film spektrális tulajdonságának jellemzése ............... 26

4.2.4. A PPy/vas-oxalát film foto-elektrokatalitikus tulajdonságának

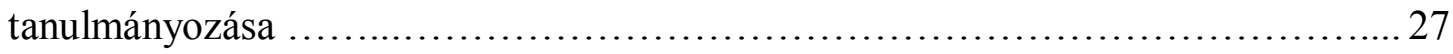


4.3. PEDOT/vas-oxalát rétegek előállítása és jellemzése

4.3.1. A PEDOT/vas-oxalát réteg elektrokémiai előállítása és vizsgálata

4.3.2. A PEDOT/vas-oxalát réteg foto-elektokatalitikus tulajdonságának tanulmányozása 32

4.3.3. A PEDOT/vas-oxalát réteg spektro-elektrokémiai vizsgálata 39

4.3.4. A PEDOT/vas-oxalát oxigén redukciójának kinetikai vizsgálata . 42

4.4.Mágneses tulajdonságú PPy réteg szintézise és jellemzése 45

4.4.1. PPy/PTO/magnetit és PPy/PTO rétegek előállítása 45

4.4.2. PPy/PTO/magnetit és PPy/PTO rétegek elektrokémiai viselkedése 46

4.4.3. PPy/PTO/magnetit és PPy/PTO rétegek katalitikus aktivitásának vizsgálata ...47

4.4.4. PPy/PTO/magnetit réteg foto-elektrokatalitikus tulajdonságának vizsgálata ... 55

5. ÖSSZEFOGLALÁS . 58

6. SUMMARY 61

7. IRODALOMJEGYZÉK 64 KÖSZÖNETNYILVÁNÍTÁS 69 


\section{Irodalmi áttekintés}

\subsection{Szerves vezető polimerek}

\subsubsection{Történeti áttekintés}

A polimerek szerves vagy szervetlen makromolekulák, amelyek egy vagy több, szabályosan ismétlődő egységből épülnek fel. A szerves polimerek két fö csoportja a természetes makromolekulás vegyületek (poliszacharidok, nukleinsavak, kaucsuk), valamint a mesterséges makromolekulás vegyületek (polisztirol, polietilén-tereftalát, poli(metilmetakrilát). Ezeknek a szintetikus anyagoknak az egyik csoportját képezik a vezető polimerek, amelyeknek a többi egyébként szigetelő tulajdonságú polimerekkel ellentétben elektromos vezetése nagyságrendekkel megváltoztatható. Ezek két fó csoportja a nyílt szénláncú (poliacetilén) és poliaromás vagy heteroaromás (polianilin, polipirrol, politiofén) rendszerek, melyek közös tulajdonsága, hogy kiterjedt konjugált $\pi$-elektronrendszerrel rendelkeznek.

Henry Letheby már 1862-ben állított elő polianilint elektrokémiai úton, mely kékes színü volt, és redukálószer hatására elszíntelenedett, majd oxidálószer jelenlétében visszanyerte kék színét [1]. 1963-ban D. E. Weiss és munkatársai jóddal adalékolt polipirrolt állítottak elő, melynek fajlagos ellenállása $1 \Omega / \mathrm{cm}$ volt [2]. A vezető polimerek sikertörténete 1977-ben kezdődött, amikor H. Shirakawa és munkatársai egy olyan halogénekkel adalékolt poliacetilént szintetizáltak, melynek vezetése elérte a fémekre jellemző értéket. Nyilvánosságra hozták azt a tényt is, hogy a két poliacatilén izomer (1.1. ábra) közül a transz izomernek sokkal nagyobb a fajlagos vezetése, mint a cisznek [3].

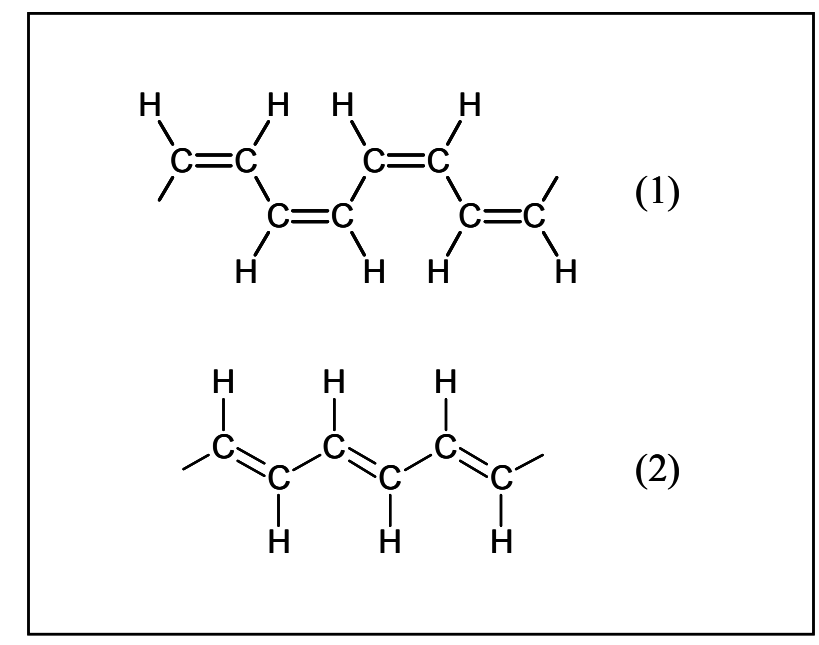

1.1. ábra Cisz-poliacetilén (1), transz-poliacetilén (2) 
1979-ben Diaz és csoportja elektrokémiai módszerrel állított elő kiemelkedő vezetésű stabil polipirrol filmet [4]. 1987-ben H. Naarmann és munkatársai egy új eljárással rendkívül rendezett szerkezetü poliacetilént hoztak létre, melynek vezetése meghaladta a korábbi, más technikával szintetizált polimerekét [5]. Ezek után más kutatók tiofénekkel és ezek szubsztituált származékaival is hasonlóan jó eredményeket értek el, melyek során a vegyületcsalád sok érdekes tulajdonságára derült fény. Mindez oda vezetett, hogy 2000-ben a Kémiai Nobel-díjat Alan J. Heeger, Alan G. MacDiarmid és Hideki Shirakawa kapták a vezető polimerek területén végzett munkásságukért.

\subsubsection{Vezető polimerek tulajdonságai}

A mai értelemben vett vezető polimerek három nagy csoportra oszthatók:

- ionvezetö polimerek

- redoxi polimerek

- elektronvezető polimerek

Az ionvezető polimerek esetében a semleges polimervázon belül az ionok elmozdulása biztosítja a vezetést. A redoxi polimereknél a szigetelő polimerváz belsejében redoxi centrumok helyezkednek el, és a vezetés ezen centrumok közötti elektronátugrással történik. Az elektronvezető polimereknél a vezetés elektronhiány vagy elektrontöbblet lánc menti elmozdulása révén valósul meg. Azonban fontos megjegyezni, hogy a láncok között elektronugrással történik a töltés vándorlása, és mivel az elektroneutralitás elvének teljesülnie kell, ezért a polimer töltését kompenzáló ionok mozgása is jellemzi, így e csoport esetében a három vezetési módozat együttesen jelentkezik.

A vezető polimerek szerkezetük szerint lehetnek:

- degenerált alapállapotú polimerek, mikor a mezomer határszerkezetük energetikailag megegyezik (poliacetilén)

- nem-degenerált alapállapotú polimerek, a mezomer határszerkezetek energetikailag különböznek (aromás, kinoidális)

A vezető polimerek főbb tulajdonságai, melyek az oxidációs állapottal megváltoznak:

- elektromos vezetés: $10^{-10}-10^{4} \mathrm{~S} / \mathrm{cm}$ között hangolható a fajlagos vezetésük

- optikai tulajdonság: színük és fényáteresztő képességük változtatható

- térfogat: ionok és oldószer beáramlásának hatására többszörösére nőhet a térfogatuk 
Irodalmi áttekintés

\subsubsection{Vezető polimerek előállítása}

A vezető polimerek előállítása döntően kémiai, illetve elektrokémiai oxidációval történik, de megvalósítható redukció útján is speciális kiindulási anyag esetén [6]. Nagyobb mennyiségü polimer szintetizálásához a kémiai eljárás a célszerü, ahol porszerü tömbfázist kapunk a polimerizáció eredményeként. Ha azonban a film jó minősége a fő szempont, akkor a finoman befolyásolható elektropolimerizációval leválasztott polimer készítése az előnyös, aminek a vastagsága jól szabályozható az áthaladó töltés mennyiségével. Ez a módszer kiválóan alkalmas vékony rétegek és módosított elektródok előállítására, melyek tulajdonságai közvetlenül vizsgálhatók.

A polimerizáció mechanizmusának az első lépésében egy igen reakcióképes gyökkation képződik a semleges monomerből. A második lépésben a monomer gyökkationok dimerizálódnak, majd a deprotonálódás történik meg, és így alakul ki a semleges dimer. A következő lépésben a semleges dimer oxidálódik gyökkationná, mivel tudjuk, hogy könnyebben oxidálható, mint a kiindulási monomerünk. Ez az oxidált dimer reagálhat semleges monomerrel vagy monomer gyökkationnal, melyet ismételten deprotonálódás követ. Ezen lépések sorozatos ismétlődésével épül fel a polimerlánc.

\subsection{Vezető polimer alapú nanokompozitok}

Mint az előzőekben láthattuk, a vezető polimerek szabályozható vezetésük, optikai tulajdonságuk és tömegváltozásuk alapján önmagukban is fontosak. De fokozatosan előtérbe került, hogy különböző tulajdonságú anyagok vezető polimerekkel történő kombinálásával új, különleges sajátságokkal rendelkezö összetett anyagokat, kompozitokat kaphatunk. Ilyenkor általában szervetlen részecskéket építenek be a szerves vezető polimer mátrixába, de lehetséges ennek a fordítottja is, amikor egy szervetlen anyagba, például polifoszfátba polimerizáltak bele polipirrolt [7]. Az utóbbi évtizedben a nanostruktúrájú anyagokkal foglalkozó tudományterület iránt egyre nagyobb érdeklődés mutatkozik. Ez nem meglepő, mivel ezek a nanoméretű részecskék számos ígéretes tulajdonságokkal rendelkeznek. Szerves vezető polimerekbe sikerült már beépíteni nemesfémeket, mint például $\mathrm{Pt}, \mathrm{Rh}, \mathrm{Pd}$ és $\mathrm{Au}[8-$ 10], és korábban már kutatócsoportunk is állított elő Ag-tartalmú polipirrol [11] és politiofén alapú nanokompozitot. Polimer nanokompozitok szintézise során alkalmaztak már számos szervetlen fém oxidot is, $\mathrm{TiO}_{2}$ [12-13], $\mathrm{Nb}_{2} \mathrm{O}_{5}$ [14], $\mathrm{V}_{2} \mathrm{O}_{5}$ [15] és vas-oxidokat [16-17]. A 
Irodalmi áttekintés

közelmúltban egy érdekes polianilin/vas-oxalát kompozitot [18] állítottak elő egy polimerizáció utáni oxidatív kezeléssel, és a Mössbauer-spektroszkópiás eredmények tükrében a szerzők megállapították, hogy egy vegyes vegyértékü vas-oxalát épül be a polianilinba.

Számos felhasználása lehetséges ezeknek a kompozitoknak, ezek közül csak néhányat mutatnék be. A korrózió elleni védelemben alkalmazható a $\mathrm{PANI} / \mathrm{Fe}_{2} \mathrm{O}_{3}$ [19] és a PPy/foszfát [20] bevonat. A PEDOT/ $\mathrm{RuO}_{2} \times \mathrm{xH}_{2} \mathrm{O}$ szerves-szervetlen nanokompozit egy ígéretes elektroaktív anyag a szuperkondenzátorok alkalmazásában [21]. Optoelektronikai eszközök alapanyaga lehet az elektrokémiailag szintetizált PPy/CdTe [22]. A poli(3-deciltiofén)/ $/ \mathrm{TiO}_{2}$ hibrid felhasználásával napelemet állítottak elő [23]. PPy/vas-oxid kompozitot szintetizáltak és tanulmányozták annak elektromágneses árnyékoló tulajdonságát [24]. Elektrokémiai reakciók katalizátorai is lehetnek, mint például a polipirrolba beépített germánium részecskék, ez az összetett anyag elektrokatalitikus aktivitást mutat az oldott oxigén és a protonok redukciója során [25].

\subsection{Vezető polimer alapú érzékelők}

Számos kedvező tulajdonságaik folytán a szerves vezető polimereken alapuló módosított elektródok érzékelőkként történő alkalmazásai mind a tudományos, mind az ipari érdeklődés fókuszában állnak [26-28]. Az egyszerü előállításuk, feldolgozhatóságuk, alacsony áruk és a viszonylag hosszú élettartamuk mind szükségessé teszik az ilyen irányú fejlesztéseket, és indokolják a további kutatásokat ezen a területen. Konjugált polimereken (polipirrol, polianilin és különböző politiofén származékok) alapuló amperometriás érzékelőket sikeresen készítettek különböző vegyületek, mint például aszkorbinsav [29-31], dopamin [32], epinefrin [33] kimutatására és mennyiségi meghatározására. E szenzoroknál jelentősen nagyobb szelektivitás, érzékenység és élettartam érhető el a vezető polimerek mátrixába szervetlen nanorészecskék vagy komplexek beépítésével. Ezek a hibridek lehetővé tehetik különböző analitok párhuzamos kimutatását (cisztein, aszkorbinsav, dopamin, oxigén, hidrogén-peroxid, stb.) Ezen célok elérésének érdekében rögzítettek különböző fémeket, többek között aranyat [34-36], platinát [37] és rezet [38], fém-oxidokat [39], fém-komplexeket [40-41], és ezek kombinációját [42] sikeresen alkalmazták különböző szerves polimerekben. Egy dodecil-benzol-szulfonáttal adalékolt polianilin érzékelőt állítottak elő, ami ammónia detektálására alkalmas vizes közegben [43]. 
$\mathrm{Az}$ oxigén mérése oldat fázisban nagy jelentőséggel bír egészségügyi, ipari és környezeti szempontból is. Az oldott oxigén meghatározását a víz minőségének megítélésére is használják, a koncentrációjának lecsökkenése jelezheti szerves szennyeződés jelenlétét. Az oxigén mérésére legszélesebb körben alkalmazott módszer a Clark elektródon alapszik [44], amit amperometriás üzemmódban használnak, mely azonban meglehetősen érzékeny a konvekció változásaira. Annak érdekében, hogy kiküszöböljék ezt a problémát, optikai szenzorokat fejlesztettek ki az oxigén meghatározására. Az egyik ilyen érzékelő alapjául szolgálhatnak az elektropolimerizációval előállított platina-tetrafenil- és oktaetil-porfirin polimerek [45]. A közelmúltban egy szénnanocsővel módosított üvegszén elektródra poli(ofenilén-diamin) vékonyréteget választottak le, ami egy jól működő elektrokémiai oxigénszenzornak bizonyult [46].

A hidrogén-peroxid detektálása és érzékelése még mindig a kutatás-fejlesztés középpontjában van. Ezen mérések többsége enzimatikus bioszenzorokon alapszik [47], ahol specifikus kölcsönhatás van a megkötött biomolekula (általában különböző enzimek) és a hidrogén-peroxid között, ami lehetővé teszi az utóbbi érzékeny mérését. Másrészt számos erőfeszítés történt annak érdekében, hogy nem-enzimatikus hidrogén-peroxid érzékelőket készítsenek [48-49], amit ezek egyszerüsége indokol. Az ilyen rendszerekben az oxigén jelenléte nem kívánatos, mivel az összes alkalmazott elektród esetében az oxigén és a hidrogén-peroxid elektrokémiai redukciójának potenciáltartománya átfedésben van, továbbá a hidrogén-peroxid az oxigén redukció köztiterméke is [50-51], ami még bonyolultabbá teszi a meghatározást. Ebből a nehézségből fakadóan, az ilyen elektródok általában vagy csak inert atmoszférában $\left(\mathrm{N}_{2}, A r\right)$, az oxigén kizárása mellett mükődnek, vagy kifinomult elektrokémiai módszerekkel (és drága elektródanyagokat használva) különböztethető meg a két spéciesz. A fent említett okok miatt továbbra is szükség van olcsó és könnyen előállítható új, e célra alkalmas elektródok vizsgálatára. A vezető polimerek leggyakoribb alkalmazása a hidrogénperoxid detektálásának területén az, amikor különböző enzimeket (torma-peroxidáz vagy mioglobin) [52-55], fém (föleg Pt) nanorészecskéket [56] vagy mediátorokat [57] építenek be a polimer mátrixába. Ami a hidrogén-peroxid közvetlen kimutatását illeti, néhány újabb tanulmány található az irodalomban: a túloxidált polipirrol ez irányú használatát DebiemmeChouvy a közelmúltban mutatta be [58], illetve a szerves festékkel kombinált PEDOT alkalmazását C. Brett és munkatársai közölték [59]. A fém-oxidok közül a magnetit $\left(\mathrm{Fe}_{3} \mathrm{O}_{4}\right)$ 
Irodalmi áttekintés

egy ígéretes ,jelölt" a fent említett célokra történő elektrokatalitikus alkalmazásokra a $\mathrm{Fe}^{3+} / \mathrm{Fe}^{2+}$ redoxi aktivitás lehetősége miatt. Ezt a viselkedést már használták különböző folyamatok, mint az oxigén vagy a hidrogén-peroxid redukciójára, mindkettő esetében nanorétegeken és rögzített nanorészecskéken [60-65].

\subsection{Vezető polimerek fotokémiai tulajdonságai}

A fotokémiai folyamat első lépése a fény hatására történő gerjesztés, amikor a reaktáns egy magasabb energiájú állapotba kerül, ezt gerjesztett állapotnak nevezzük (1.2. ábra). A reaktáns közvetlenül is abszorbeálhatja a fotont, vagy felhasználhatja egy úgynevezett érzékenyítő segítségével, ami maga nyeli el először a fotont, majd átadja az energiát a reaktánsnak.

Félvezető anyagokban a fotokatalízis során fény hatására elektron-lyuk párok keletkeznek, amik részvételével redoxi folyamatok indulhatnak el. Ennek során a besugárzott fény energiája az elektrokémiai folyamat sebességét növeli. Ezt a jelenség együttest nevezzük foto-elektrokatalízisnek.

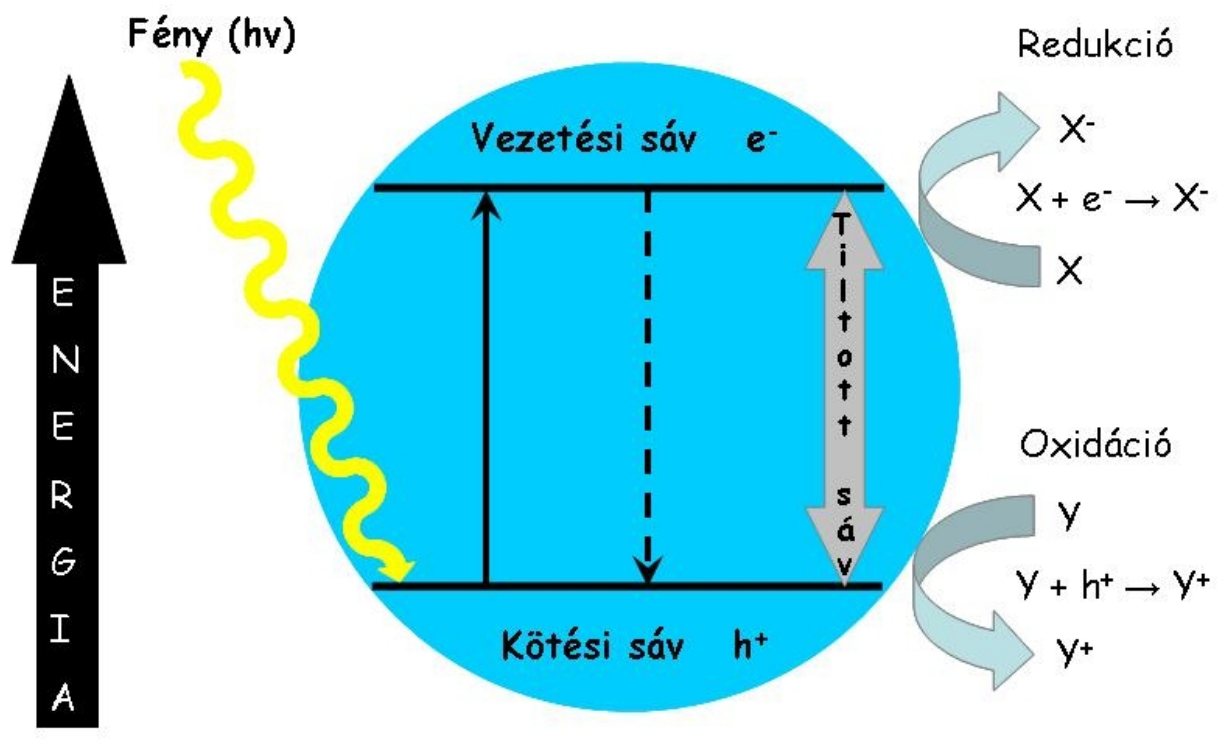

1.2. ábra Fotokémia sematikus bemutatása

Az elektromosan vezető polimerek fotoelektrokémiai viselkedését már az 1990-es években vizsgálni kezdték [66-67]. A polianilin fény besugárzásának hatására katódos és anódos fotoáramot is produkál, míg a polipirrol és a poli(3-metiltiofén) redukciós fotoáramot mutat, ami a p-típusú félvezető tulajdonságát jelzi [68]. A polipirrol esetében a túloxidáció 
Irodalmi áttekintés

hatására a fotoáram intenzitása csökken [69], ezért nagyon fontos megtalálni az optimális tartományt az elektrokémiai vizsgálatok során.

A fotoelektrokémiai aktivitás tovább növelhető, ha a szerves vezető polimereket más félvezető tulajdonsággal rendelkező anyaggal kombináljuk össze. Ezek széles spektrumát mutatja, hogy elöállítottak és jellemeztek már pl. PANI/CdS, PANI/Cu $\mathrm{Cu}_{2} \mathrm{~S}$ [70], poli(3,4dioktiloxitiofén)/CdS [71] és poli(3-oktiltiofén)/ZnO [72] kompozitokat. 


\section{Célkitűzés}

A szakirodalomból nyert, az előzőekben felsorolt ismeretek kiegészítéseként, valamint kutatócsoportunk korábbi tapasztalatai alapján új, eddig még nem vagy csak kevéssé vizsgált polimereken alapuló kompozit elektródok előállítását terveztük.

Célunk volt egyrészt a hidrogén-peroxidos utókezeléssel [18] történő szintézismódszer poli(3-oktil-tiofén) és polipirrol alapú vas-oxalát kompozitok előállítására való kiterjesztése.

Ezen túlmenően a vezető polimer/vas-oxalát összetett anyagok elektrokémiai szintézisét is meg kívántuk valósítani. Koncepciónk az volt, hogy a vízben igen rosszul oldódó vas-oxalát jelenlétében egyéb vezetősó nélkül olyan monomert alkalmazzunk, melyből vizes közegben is elektromosan vezető polimer választható le (pirrol, 3,4-etilén-dioxi-tiofén).

Fontosnak tartottuk továbbá az előállított kompozitok elektrokémiai jellemzését és tulajdonságaik széleskörü tanulmányozását is.

A kutatócsoportunkban folyó korábbi vizsgálatok során fény derült arra, hogy a magnetit tartalmú polipirrol elektródon a hidrogén-peroxid jelenlétéhez köthető amperometriás technikával mért áram - igen kis koncentrációk esetén is - egyenesen arányos annak koncentrációjával [73]. Így ezt az elektrokatalitikus tulajdonságot részletesebben kívántuk tanulmányozni.

Ebböl kiindulva kiemelt célként terveztük a különböző vasvegyületeket, illetve nanorészecskéiket tartalmazó polimerek fotokatalitikus sajátságainak vizsgálatát, a fotoelektrokémiai viselkedés részletes tanulmányozását és az esetleges analitikai alkalmazás lehetőségének felderítését. 
Felhasznált anyagok, müszerek és módszerek

\section{Felhasznált anyagok, müszerek és módszerek}

\subsection{Felhasznált anyagok}

Poli(3-oktil-tiofén) kémiai elóállításához:

- 3-oktil tiofén monomer $\left(\mathrm{C}_{12} \mathrm{H}_{20} \mathrm{~S}\right.$, Sigma-Aldrich, $\left.\mathrm{M}_{\mathrm{r}}=196,36\right)$

- vízmentes vas(III)-klorid ( $\mathrm{FeCl}_{3}$, Riedel-de Haën, $\left.\mathrm{M}_{\mathrm{r}}=162,20\right)$

- kloroform $\left(\mathrm{CHCl}_{3}\right.$, Molar Chemicals, $\left.\mathrm{M}_{\mathrm{r}}=119,38\right)$

- absz. etanol $\left(\mathrm{C}_{2} \mathrm{H}_{5} \mathrm{OH}\right.$, Molar Chemicals, $\left.\mathrm{M}_{\mathrm{r}}=46,09\right)$

Polipirrol kémiai eloólllításához:

- vákuumdesztillált pirrol monomer $\left(\mathrm{C}_{4} \mathrm{H}_{5} \mathrm{~N}\right.$, Sigma-Aldrich, $\left.\mathrm{M}_{\mathrm{r}}=67,09\right)$

- vas(III)-nitrát $\left(\mathrm{Fe}\left(\mathrm{NO}_{3}\right)_{3} \times 9 \mathrm{H}_{2} \mathrm{O}\right.$, Reanal, $\left.\mathrm{M}_{\mathrm{r}}=404,00\right)$

POT és PPy alapú vas-oxalát kompozitok kémiai elóállitásához:

- vas(III)-klorid $\left(\mathrm{FeCl}_{3} \times 6 \mathrm{H}_{2} \mathrm{O}\right.$, Reanal, $\left.\mathrm{M}_{\mathrm{r}}=270,30\right)$

- ammónium-oxalát $\left(\left(\mathrm{NH}_{4}\right)_{2} \mathrm{C}_{2} \mathrm{O}_{4} \times \mathrm{H}_{2} \mathrm{O}\right.$, Reanal, $\left.\mathrm{M}_{\mathrm{r}}=142,11\right)$

- $30 \%$-os hidrogén-peroxid (cc. $\mathrm{H}_{2} \mathrm{O}_{2}$, Reanal, $\mathrm{M}_{\mathrm{r}}=34,02$ )

$\underline{\text { PPy/vas-oxalát filmek elektrokémiai elöállításához: }}$

- vákuumdesztillált pirrol monomer $\left(\mathrm{C}_{4} \mathrm{H}_{5} \mathrm{~N}\right.$, Sigma-Aldrich, $\left.\mathrm{M}_{\mathrm{r}}=67,09\right)$

- nátrium-dodecil-szulfát $\left(\mathrm{C}_{12} \mathrm{H}_{25} \mathrm{NaO}_{4} \mathrm{~S}\right.$, Sigma-Aldrich, $\left.\mathrm{M}_{\mathrm{r}}=288,38\right)$

- vas(II)-oxalát $\left(\mathrm{FeC}_{2} \mathrm{O}_{4} \times 2 \mathrm{H}_{2} \mathrm{O}\right.$, Sigma-Aldrich, $\left.\mathrm{M}_{\mathrm{r}}=143,86\right)$

PEDOT/vas-oxalát réteg elektrokémiai elóállitásához:

- etilén-dioxi-tiofén monomer $\left(\mathrm{C}_{6} \mathrm{H}_{6} \mathrm{O}_{2} \mathrm{~S}\right.$, Bayer, $\left.\mathrm{M}_{\mathrm{r}}=142,18\right)$

- vas(II)-oxalát $\left(\mathrm{FeC}_{2} \mathrm{O}_{4} \times 2 \mathrm{H}_{2} \mathrm{O}\right.$, Sigma-Aldrich, $\left.\mathrm{M}_{\mathrm{r}}=143,86\right)$

PPy/PTO/magnetit és PPy/PTO rétegek elóállitásához:

- vákuumdesztillált pirrol monomer $\left(\mathrm{C}_{4} \mathrm{H}_{5} \mathrm{~N}\right.$, Sigma-Aldrich, $\left.\mathrm{M}_{\mathrm{r}}=67,09\right)$

- kálium-tetraoxalát-dihidrát $\left(\mathrm{KH}_{3}\left(\mathrm{C}_{2} \mathrm{O}_{4}\right)_{2} \times 2 \mathrm{H}_{2} \mathrm{O}\right.$, Fluka, $\left.\mathrm{M}_{\mathrm{r}}=254,19\right)$

- magnetit nanorészecske $\left(\mathrm{Fe}_{3} \mathrm{O}_{4}, \mathrm{M}_{\mathrm{r}}=231,55\right)$ átlagos részecskeméret $12 \mathrm{~nm}$

Elektrokémiai mérésekhez:

- nátrium-szulfát $\left(\mathrm{Na}_{2} \mathrm{SO}_{4}\right.$, Finomvegyszer Szövetkezet Bp., $\left.\mathrm{M}_{\mathrm{r}}=142,04\right)$

- nátrium-dihidrogén-foszfát-hidrát $\left(\mathrm{NaH}_{2} \mathrm{PO}_{4} \cdot \times \mathrm{H}_{2} \mathrm{O}\right.$, Reanal, $\left.\mathrm{M}_{\mathrm{r}}=137,99\right)$ 
- dinátrium-hidrogén-foszfát-dihidrát $\left(\mathrm{Na}_{2} \mathrm{HPO}_{4} \cdot \times 2 \mathrm{H}_{2} \mathrm{O}\right.$, Reanal, $\left.\mathrm{M}_{\mathrm{r}}=177,99\right)$

- kálium-nitrát $\left(\mathrm{KNO}_{3}\right.$, Reanal, $\left.\mathrm{M}_{\mathrm{r}}=101,11\right)$

- kálium-klorid ( $\mathrm{KCl}$, Reanal, $\left.\mathrm{M}_{\mathrm{r}}=74,56\right)$

- kálium-hidrogénkarbonát $\left(\mathrm{KHCO}_{3}\right.$, Sigma-Aldrich, $\left.\mathrm{M}_{\mathrm{r}}=100,12\right)$

- nátrium-klorid ( $\mathrm{NaCl}$, Reanal, $\left.\mathrm{M}_{\mathrm{r}}=58,44\right)$

- nátrium-nitrát $\left(\mathrm{NaNO}_{3}\right.$, Reanal, $\left.\mathrm{M}_{\mathrm{r}}=84,99\right)$

- $30 \%$-os hidrogén-peroxid (cc. $\mathrm{H}_{2} \mathrm{O}_{2}$, Reanal, $\mathrm{M}_{\mathrm{r}}=34,02$ )

- oxigén $\left(\mathrm{O}_{2}\right.$, Messer, $\left.\mathrm{M}_{\mathrm{r}}=32,00\right)$

- nitrogén $\left(\mathrm{N}_{2}\right.$, Messer, $\left.\mathrm{M}_{\mathrm{r}}=28,01\right)$

- $\mathrm{Ag} / \mathrm{AgCl}$ referenciaelektród (BASI RE-5B, 3M NaCl) E = 0,200 V vs. SHE

Minden felhasznált vegyszer analitikai tisztaságú volt. A vizes oldatokat Milli-Q RG Millipore víztisztító berendezésben tisztított ioncserélt vízzel készítettem, melynek a fajlagos ellenállása 18,2 M $\Omega \mathrm{cm}$ volt. A magnetit nanorészecskéket a Dr. Tombácz Etelka által vezetett Vizes Kolloidok Csoport állította elő egy koprecipitációs eljárással [74]

\subsection{Mérőmüszerek}

- Orion 3 Star, oxigéntartalmat mérő érzékelő

- AUTOLAB PGSTAT10 számítógép vezérelt elektrokémiai mérőrendszer

- Agilent 8453 UV-Vis diódasoros spektrofotométer

- Philips PW-1830 röntgendiffraktométer

- QCA917 (EG\&G Seiko) elektrokémiai kvarckristály-mikromérleg

- Hitachi S-4700 pásztázó elektronmikroszkóp

- Röntec QX2 típusú energiadiszperzív röntgen-analizátor

- Spectra-Physics 404 típusú fényintenzitás mérö

\subsection{Mérési módszerek}

Elektrokémiai mérések

Az elektrokémiai méréseket egy PGSTAT 10 potenciosztát-galvanosztát segítségével (AUTOLAB) végeztük, mely számítógép vezérléssel alkalmas volt dinamikus és stacionárius mérések elvégzésére. Méréseink során klasszikus háromelektródos elektrokémiai cellát 
Felhasznált anyagok, müszerek és módszerek

használtunk, ahol a munkaelektród Pt elektród volt, de a forgó korongelektródos vizsgálatokhoz Au elektródot, míg a spektro-elektrokémiai mérésekhez ITO-val bevont felületü üveglapot alkalmaztunk munkaelektródként. Minden esetben $\mathrm{Ag} / \mathrm{AgCl} / 3 \mathrm{M} \mathrm{NaCl}$ elektródot használtunk referenciaelektródként, melynek potenciálja 0,200 V a SHE-hez képest. Ellenelektródként Pt lemezt vagy Pt szálat alkalmaztunk. Az elektrokémiai kvarckristály mikromérleggel történő méréseket egy QCA917, EG\&G Seiko készülékkel végeztük el, ahol a munkaelektród a kvarckristályra felvitt Au réteg volt. Ezzel a technikával az elektrokémiai folyamatokat kísérő rendkívül kicsi felületi tömegváltozásokat mérhetünk.

\section{Röntgendiffrakciós vizsgálatok}

Méréseinkhez egy Philips PW-1830 típusú röntgendiffraktométert használtunk $(2 \Theta=$ $\left.2-80^{\circ}\right)$, a besugárzás a $\mathrm{CuK}_{\alpha}$ vonalán történt $(\lambda=0,1542 \mathrm{~nm}), 40 \mathrm{kV}$ és $30 \mathrm{~mA}$ mellett. Ez a vizsgálati módszer a vegyületek kristályformáinak meghatározására alkalmas és az anyagi minőségre jellemző egyértelmü információt ad. A kiértékelés során JCPDS kártyák adataival hasonlítottuk össze az általunk mért röntgendiffraktogramok reflexiós értékeit.

Mössbauer-spektroszkópiás mérések

Az elektrokémiailag elóállított kompozit ${ }^{57} \mathrm{Fe}$ Mössbauer spektrumának felvétele $10^{9}$ $\mathrm{Bq}{ }^{57} \mathrm{Co}(\mathrm{Rh})$ forrás alkalmazásával transzmissziós módban történt. Az izomereltolódás értékeket az $\alpha$-vashoz viszonyítva adjuk meg. Ezzel a módszerrel meghatározható, hogy tartalmaz-e a vasat a minta, és a vas milyen formában található meg benne.

Pásztázó elektronmikroszkópiás vizsgálatok

Méréseinket egy Hitachi S-4700 pásztázó elektronmikroszkópon végeztük, a SEM-be beépített Röntec QX2 típusú energiadiszperzív röntgen-analizátor segítségével a felület vizuális vizsgálatával egyidőben lokális elemanalitikai vizsgálatot is végrehajtottunk. A SEM felvételek alapján polimer réteg morfológiájáról kaphatunk információkat. 
Eredmények és értékelésük

\section{Eredmények és értékelésük}

\subsection{POT/vas-oxalát és PPy/vas-oxalát kompozitok kémiai előállítása és vizsgálata}

Ebben a fejezetben bemutatom az első kísérleteinket kompozitok előállítására, ahol a kémiai polimerizációval frissen elóállított vezető polimerekbe építettünk be vas-oxalátot hidrogén-peroxidos utókezeléssel.

\subsubsection{POT kémiai előállítása}

A kémiai polimerizáció vízmentes körülmények között történt. Oldószerként kloroformot használtunk, az oxidálószer vízmentes vas(III)-klorid volt. A vas só oldhatóságát nagymértékben befolyásolja az oldószer víztartalma, illetve oldhatóságának mértékét a szerves oldószer anyagi minősége korlátozza. A gyakorlati eljárás a következő lépésekböl állt: 200 $\mathrm{cm}^{3}$ kloroformban a megfelelő mennyiségü oxidálószert $\left(\mathrm{FeCl}_{3}\right)$ mágneses keverővel kevertettük feloldódásig, hogy 0,25 M-os oldatot kapjunk, majd az oldat hőmérsékletét jeges fürdőben $0^{\circ} \mathrm{C}$-ra csökkentettük, ezután kevertetés mellett cseppenként adtuk hozzá a monomert 0,1 M koncentrációban. A polimer megjelenése így pillanatszerü, amit a színváltozás azonnal mutat. A kevertetést $0^{\circ} \mathrm{C}$-on két óra hosszáig, majd szobahőmérsékleten 24 órán keresztül végeztük. A kivált szilárd polimert szürtük, alkohollal dekantálva többször mostuk, és jól kiszárítottuk.

\subsubsection{PPy kémiai szintézise}

Ebben az esetben a kémiai polimerizáció vizes közegben történt. Oxidálószerként kristályvizes vas(III)-nitrátot használtunk, amiből $500 \mathrm{~cm}^{3}$ 0,25 M-os oldatot készítettünk. Ezután mágneses kevertetés mellett cseppenként adagoltuk hozzá az átdesztillálás után kapott valóban monomernek tekinthető pirrolt, mivel köztudott, hogy állás közben spontán polimerizálódhat, ezért sárgásbarna színủ az oligomereket tartalmazó oldat. Az oldat monomer koncentrációja $0,1 \mathrm{M}$ volt. A polimer megjelenése pillanatszerü, de a folyamat teljes lejátszódása érdekében két órán át még kevertettük a rendszert. A kivált polimert szürtük, desztillált vízzel mostuk, és jól kiszárítottuk. 


\subsubsection{POT és PPy alapú vas-oxalát kompozitok kémiai előállítása}

Kristályvizes vas(III)-klorid és kristályvizes ammónium-oxalát felhasználásával oldatot készítettünk. Az irodalomban ismert komplex anion (4.1. ábra) kialakulását, az oldat zöld színe is jelezte. Ezután a kész polimer (POT illetve PPy) hozzáadása következett, ehhez adagoltuk a 30 \%-os hidrogén-peroxidot, melynek során gázfejlődést tapasztaltunk. Az egy órás kevertetés után az elegyet állni hagytuk, majd leszürtük és mostuk, végül levegőn néhány

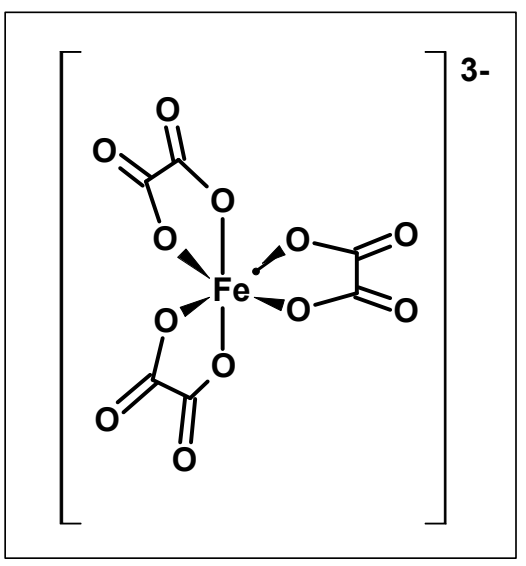
napig szárítottuk.

\section{1. ábra Trioxaláto-ferrát(III) komplex anion}

\subsubsection{A kompozitok anyagszerkezetének vizsgálata}

Az elöállított polimereket és a polimer alapú vas-oxalát kompozitokat röntgendiffrakciós módszerrel vizsgáltuk. Célunk volt a kompozit képződésének kimutatása a „tiszta” polimerrel való összehasonlítása alapján.

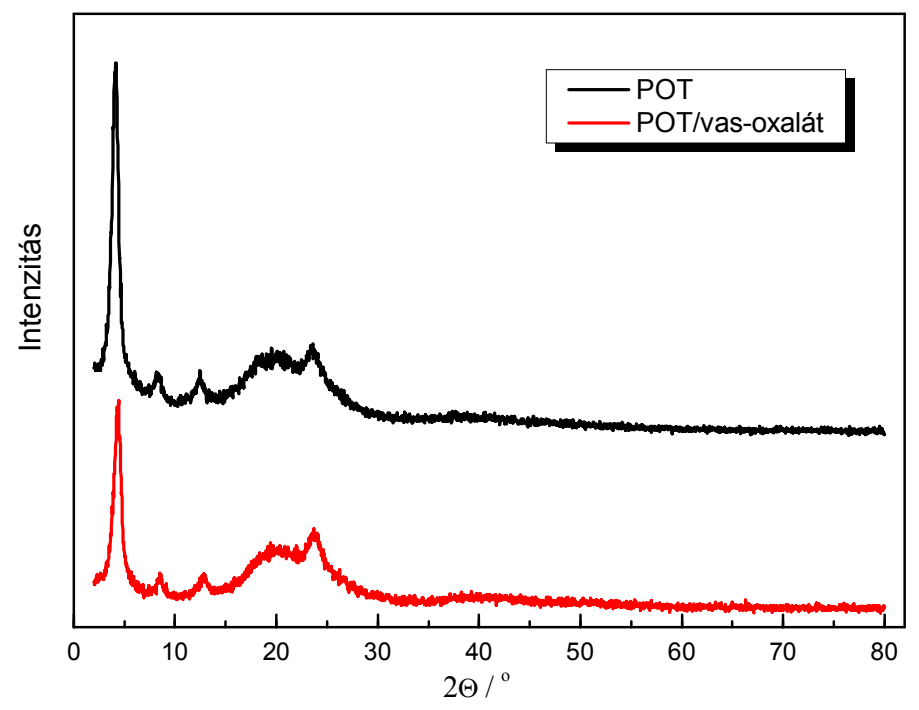

4.2. ábra A POT és a POT/vas-oxalát kompozit XRD felvétele

A poli(3-oktil-tiofén)-nek a röntgendiffrakciós spektruma a 4.2. ábrán látható. Ezen egy széles, lapos reflexió figyelhető meg $15-28^{\circ}$-nál, ez azokra a polimerekre jellemző, 
Eredmények és értékelésük

melyeknek amorf szerkezete van. A POT esetében szerkezetre utaló reflexiók is megjelennek $4^{\circ}, 8^{\circ}$ és $12^{\circ}$-nál, ami az oldalláncok közötti kölcsönhatások lamelláris szerkezetet eredményező rendező hatásával magyarázható. A 23,5ำ-nál lévő reflexió a konjugált láncok közötti, az oxidált állapotban a gyökkation-gyökkation kölcsönhatással ( $\pi$-stack) [75] hozható összefüggésbe. Ezen adatokból a Bragg-egyenlet $(n \times \lambda=2 \times d \times \sin \Theta)$ felhasználásával

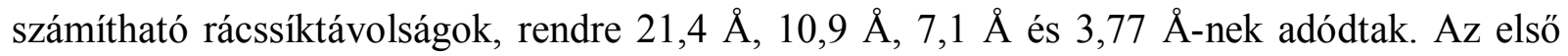
három értékböl (felharmonikusok) arra következtethetünk, hogy réteges polimer szerkezet is kialakul. Továbbá ezen az ábrán látható a POT/vas-oxalát XRD felvétele. A POT-ra jellemző reflexiókon kívül nem jelennek meg újak, tehát a beépített vas-oxalát önálló kristályos fázisként nem mutatható ki, de jelenléte sejthető az első három reflexió szisztematikus eltolódásából. A $4^{\circ}$-nál található reflexió intenzitásának csökkenése a polimeréhez képest a kristályos szerkezet csökkenésével állhat kapcsolatban.

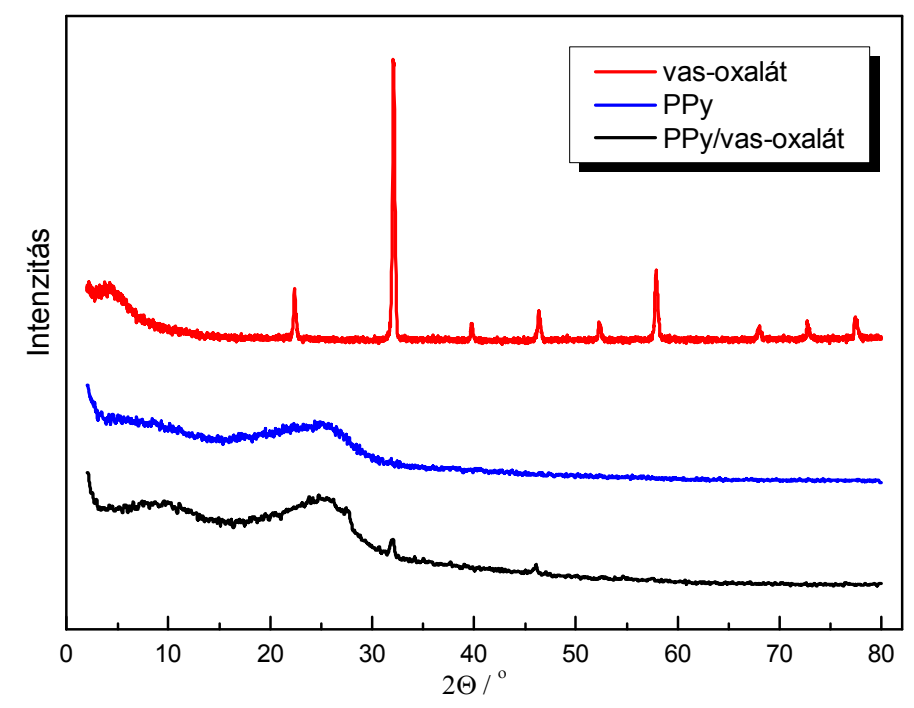

4.3. ábra A vas-oxalát, a PPy és a PPy/vas-oxalát kompozit XRD felvétele

A PPy/vas-oxalát kompozit esetében két új reflexió jelenik meg a tiszta polimerhez képest (4.3. ábra). Az azonosításhoz felvettük a vas-oxalát komplex diffraktogramját, amin kilenc reflexiót láthatunk, ebből legalább kettő - $32^{\circ}$ és $46^{\circ}$ - egyértelműen megjelenik a kompozit XRD felvételén is. Ezek alapján megállapíthatjuk, hogy a vastartalmú komponens jelen van a polimerünkben. 
Eredmények és értékelésük

4.2. PPy/vas-oxalát filmek elektrokémiai előállítása és jellemzése

Megkíséreltük a PPy/vas-oxalát elektrokémiai szintézisét, ezt azon elgondolás alapján kívántuk megvalósítani, hogy a polipirrol réteg leválasztásakor csak a vas(II)-oxalát, mint rosszul oldódó só van jelen az oldatban. Így mindenféleképpen valamilyen vas tartalmú oxalát anionnak kell kompenzálnia a polimer pozitív töltéseit.

\subsubsection{PPy/vas-oxalát filmek elektrokémiai előállítása}

Potenciosztatikus módban

A ciklikus voltammetriával vizsgált polipirrol filmek leválasztása anódos oxidációval történt egy $4 \mathrm{~cm}^{2}$ felületü platina elektródra. $0,65 \mathrm{~V}$ potenciálon minden egyes film elkészítésekor $240 \mathrm{mC}$ töltés mennyiség haladt keresztül. Ezt követően hagytuk az elkészült rétegeket relaxálódni abból a célból, hogy deszolvatációval kialakuljon a jól vezető szerkezet [76]. A munkaelektród potenciálját minden mérés során $\mathrm{Ag} / \mathrm{AgCl}$ referenciaelektróddal szemben mértük. A minták az elektropolimerizáció során használt oldat összetételében különböztek egymástól. A monomer az összes rendszerben jelen volt, a nátrium-dodecilszulfát és a vas(II)-oxalát mennyisége változott, amit az 4.1. táblázat mutat be. Az SDS adagolására azért volt szükség, mert a rosszul oldódó vas-oxalát nem biztosította az oldat szükséges vezetését. De összehasonlító vizsgálattal e hatást is tanulmányoztuk.

4.1. táblázat Az elektrokémiai szintézisekhez használt oldatok összetételei

\begin{tabular}{|c|c|c|c|}
\hline Minta & $\mathrm{c}($ pirrol) / M & $\mathrm{c}(\mathrm{SDS}) / \mathrm{M}$ & $\mathrm{c}($ vas(II)-oxalát) / M \\
\hline PPy/SDS & 0,1 & 0,1 & - \\
\hline PPy/vas-oxalát & 0,1 & - & telített oldat \\
\hline PPy/SDS/vas-oxalát & 0,1 & 0,1 & telített oldat \\
\hline
\end{tabular}

Galvanosztatikus módban

A pásztázó elektronmikroszkópiás, az elektrokémiai kvarckristály mikromérleg technikás és a Mössbauer-spektroszkópiás mérésekhez 0,1 M monomer és telített vas(II)oxalát oldatából $3 \mathrm{~mA} / \mathrm{cm}^{2}$ áramsürüség alkalmazásával készültek a filmek.

\subsubsection{PPy filmek elektrokémiai viselkedése}

Annak érdekében, hogy a polipirrol alapú összetett anyagok elektrokémiai tulajdonságait vizsgáljuk, kísérletet tettünk a kompozitok in situ elektrokémiai szintézisére a korábban már említett, különböző összetételü oldatokból. Az előállítások potenciosztatikus 
Eredmények és értékelésük

módszerrel, azonos potenciálon, azonos töltésmennyiség áthaladásával történtek egy $4 \mathrm{~cm}^{2}$ felületủ platina elektródon. Az elkészített filmek redoxi tulajdonságainak tanulmányozása érdekében ciklikus voltammetriás méréseket végeztünk. Mindhárom film esetében $+0,25 \mathrm{~V}$ és $-0,95 \mathrm{~V}$ közötti tartományban történt az elektrokémiai vizsgálat. A filmeket 0,1 M-os SDS oldatban különböző ciklizálási sebesség alkalmazása mellett több ciklusban oxidáltuk és redukáltuk. A 4.4. ábrán a stacionáriussá vált harmadik ciklus látható minden egyes filmnél 25 $\mathrm{mV} / \mathrm{s}$ ciklizálási sebesség esetén. Az irodalomban egyébként ideális viselkedésünek tartott, nátrium-dodecil-szulfát oldatban készített (PPy/SDS) filmhez [77] képest a PPy/vas-oxalát film töltéskapacitása valamivel kisebb, a vegyes iontartalmú oldatban szintetizált film (PPy/SDS/vas-oxalát) pedig az elsővel mutat hasonló tulajdonságokat.

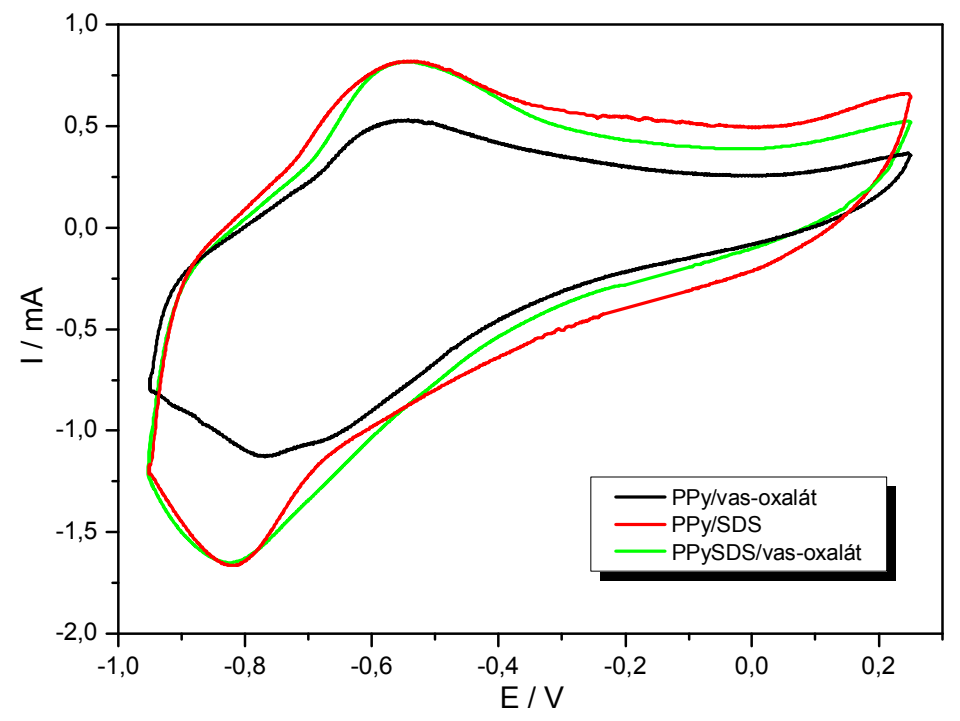

4.4. ábra A PPy/vas-oxalát, PPy/SDS és a PPy/SDS/vas-oxalát filmek ciklikus voltammogramja $25 \mathrm{mV} / \mathrm{s}$ ciklizálási sebességgel

\subsubsection{A kompozitok jellemzése}

\subsubsection{Pásztázó elektronmikroszkópiás és elemanalitikai vizsgálatok}

$\mathrm{Az}$ eloállított kompozitok morfológiájának tanulmányozása érdekében SEM felvételeket készítettünk. A PPy/SDS és a PPy/vas-oxalát mintákról $10000 \times$ nagyítás mellett felvett SEM képeken (4.5. ábra) tisztán látható a SDS jelenlétében készült film karfiol-szerü 
felépítése, ami könnyen megkülönböztethető a vas(II)-oxalátot tartalmazó oldatból leválasztott rétegtől, ahol a felületi inhomogenitások sokkal kifejezettebbek.

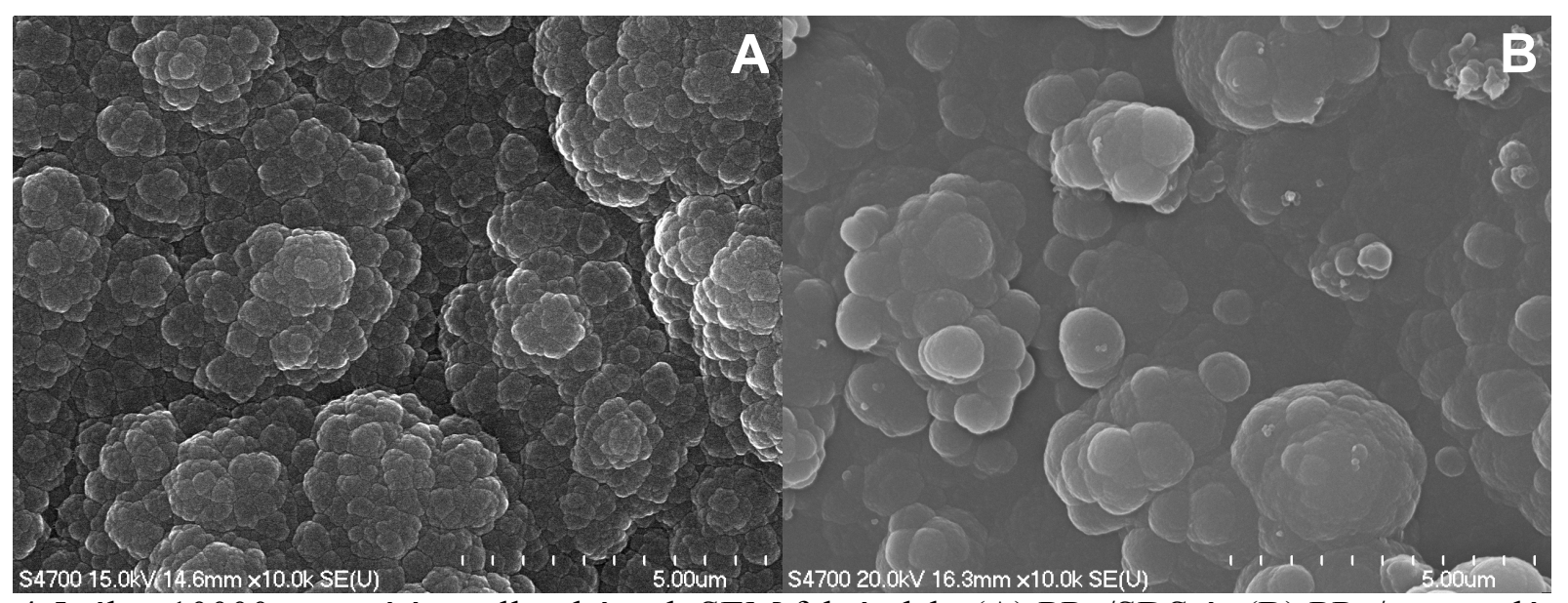
4.5. ábra 10000× nagyítás mellett készült SEM felvételek: (A) PPy/SDS és (B) PPy/vas-oxalát

A két polimer minta kémiai összetételét EDX mérésekkel határoztuk meg. A PPy/SDS (4.6. ábra) és a PPy/vas-oxalát (4.7. ábra) spektrumain jól láthatók a polimerhez tartozó C és $\mathrm{N}$ csúcsok. A SDS jelenlétében preparált réteg esetében kiemelkedően intenzív S csúcs jellegzetesen eltér a PPy/vas-oxalát filmtől, aminek a spektrumán nyilvánvalóan látszik a vashoz rendelhető három gerjesztési energia érték.

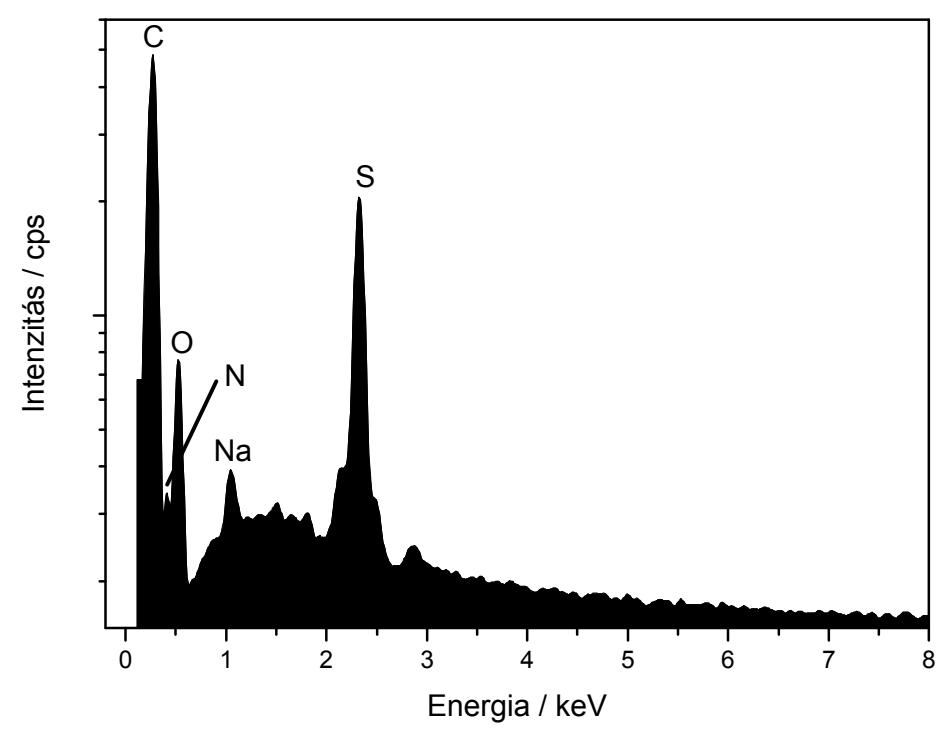

4.6. ábra A PPy/SDS EDX spektruma 
A 4.6. ábrán az SDS beépülését mutatják a S, O és Na jelei, míg a 4.7. ábrán a Fe és az $\mathrm{O}$ csúcsai a vas-oxalát jelenlétét bizonyítják. A beépült vas mennyisége kb. 5 tömeg \%.

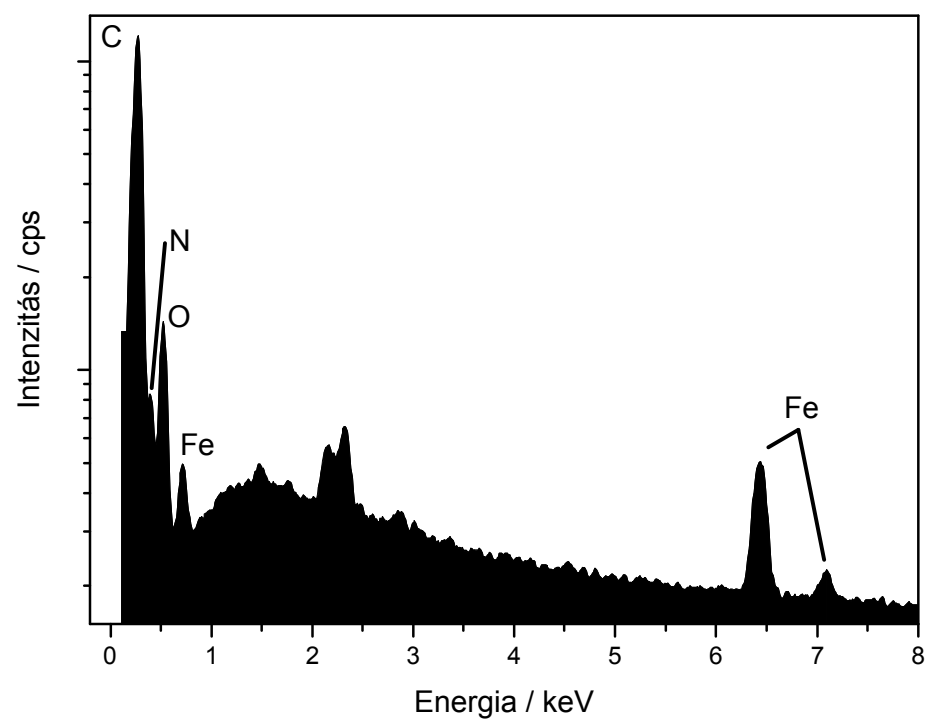

\section{7. ábra A PPy/vas-oxalát EDX spektruma}

\subsubsection{A PPy/vas-oxalát film EQCM vizsgálata}

Annak érdekében, hogy további információkat szerezzünk a PPy/vas-oxalát filmről, galvanosztatikusan, $3 \mathrm{~mA} / \mathrm{cm}^{2}$ áramsürüség és $60 \mathrm{mC} / \mathrm{cm}^{2}$ töltéssürüség alkalmazásával választottuk le a réteget, amit in situ EQCM technikával követtünk. Azért választottuk ezt a töltéssürüséget, ami meghatározza a rétegvastagságot, hogy elkerüljük a viszkoelasztikus hatást [78]. A 4.8. ábrán a kvarckristály frekvenciaváltozását ábrázoltuk a polimerizációs idő függvényében. Az egységnyi felületre eső tömegváltozást a Sauerbrey [79] egyenlettel számoltuk ki, így az eredményt $\mu \mathrm{g} / \mathrm{cm}^{2}$-ben kaptuk meg.

$$
\Delta m=\frac{4,417 \times 10^{11} \times \Delta f}{f_{o} \times f},
$$

ahol $\mathrm{f}_{\mathrm{o}}$ a kezdeti frekvencia, $\mathrm{f}$ a végső frekvencia és $\Delta \mathrm{f}$ az előző kettő különbsége. Ha figyelembe vesszük, hogy az elektropolimerizáció alatt állandó volt az áramerősség, akkor $0,489 \mu \mathrm{g} / \mathrm{mC}$ meredekséget kapunk.

A monomeregységre jutó virtuális moláris tömeg kiszámolható, ha meg tudjuk határozni az oxidációs (dopolási) szintet [80]. Ennek kiszámolásához a következő egyenletet 


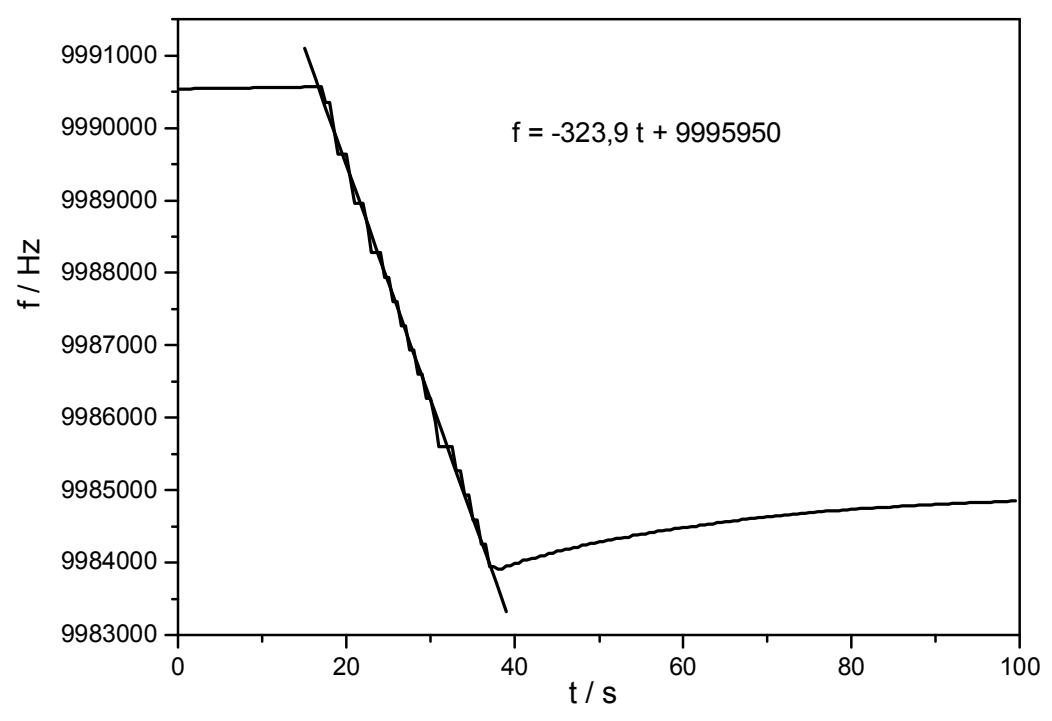

4.8. ábra EQCM mérés: a PPy/vas-oxalát film leválasztása során

használhatjuk fel, ha feltételezzük, hogy a film oxidációs állapota az anódos polarizáció végpotenciálján és a polimerizáció végén megegyezik.

$$
d=\frac{2 \mathrm{Q}_{o x}}{\mathrm{Q}_{p o l}-\mathrm{Q}_{o x}}
$$

Az oxidációs töltés $\left(\mathrm{Q}_{\mathrm{ox}}\right)$ a film SDS-ben $25 \mathrm{mv} / \mathrm{s}$ ciklizálási sebesség mellett történő oxidációja alatt, míg a polimerizációs töltés $\left(\mathrm{Q}_{\mathrm{pol}}\right)$ a film polimerizációja során áthaladt össztöltésből adódik [81]. A számolás alapján 0,15 értéket kaptunk, mely az irodalomban meghatározott értékek tartományába esik.

Az előbb kapott adat felhasználásával kiszámoltuk néhány kézenfekvőnek adódó vagy lehetséges beépülő anion esetén a monomeregységre vonatkozó virtuális moláris tömeget és az egységnyi töltés hatására bekövetkező tömegváltozást, melyeket a 4.2. táblázatban foglaltuk össze. A számítások alapja a következő: a pirrol moláris tömege $67 \mathrm{~g} / \mathrm{mol}$, a polimerizáció során deprotonálódás történik, így ez az érték a két proton tömegét levonva $65 \mathrm{~g} / \mathrm{mol}$ lesz. Az oxidációs szintet és a polimeren kialakult pozitív töltést kompenzáló anionok töltésszámát figyelembe véve kapjuk meg a monomeregységre vonatkozó virtuális tömegeket. Ezeket az értékeket elosztva az adott monomeregység kialakulásához szükséges elektronátmenetek számának megfelelő töltéssel adódik az egységnyi töltés hatására bekövetkező tömegváltozás. Ennek kísérleti értéke volt $0.489 \mu \mathrm{g} / \mathrm{mC}$. 
Eredmények és értékelésük

4.2. táblázat Néhány lehetséges beépülő anionra vonatkozó számolt értékek

\begin{tabular}{|c|c|c|c|}
\hline Beépülő anion & $\mathrm{M}(\mathrm{g} / \mathrm{mol})$ & Monomeregységre jutó $\mathrm{M}(\mathrm{g} / \mathrm{mol})$ & Számolt $(\Delta \mathrm{m} / \Delta \mathrm{Q}) /(\mu \mathrm{g} / \mathrm{mC})$ \\
\hline ox $^{2-}$ & 88 & $65+0,15 \times(88 / 2)=71,6$ & $71,6 /(2,15 \times 96485)=0,345$ \\
\hline$\left[\mathrm{Fe}(\mathrm{III})(\mathrm{ox})_{3}\right]^{3-}$ & 320 & $65+0,15 \times(320 / 3)=81,0$ & $81,0 /(2,15 \times 96485)=0,390$ \\
\hline$\left[\mathrm{Fe}(\mathrm{II})(\mathrm{ox})_{2}\right]^{2-}$ & 232 & $65+0,15 \times(232 / 2)=82,4$ & $82,4 /(2,15 \times 96485)=0,397$ \\
\hline$\left[\mathrm{Fe}(\mathrm{II}) \mathrm{Fe}(\mathrm{III})(\mathrm{ox})_{3}\right]^{-}$ & 376 & $65+0,15 \times(376 / 1)=121,4$ & $121,4 /(2,15 \times 96485)=0,585$ \\
\hline
\end{tabular}

A táblázat utolsó sorában egy vegyes vegyértékü két vasat tartalmazó komplex anion szerepel, melynek képződésére az irodalom szerint van reális lehetőség [18]. Láthatóan az első három esetben a számolt $(\Delta \mathrm{m} / \Delta \mathrm{Q})$ lényegesen kisebb, mint a kísérletileg meghatározott 0,489 $\mu \mathrm{g} / \mathrm{mC}$ érték. Figyelembe véve, hogy csak a vegyes vegyértékü komplex anionra kapott 0,585 $\mu \mathrm{g} / \mathrm{mC}$ nagyobb, mint a kísérleti adat, ebböl arra következtethetünk, hogy a rétegnek tartalmaznia kell ezt az aniont is.

\subsubsection{Mössbauer-spektroszkópiás vizsgálatok}

Az elöbbiekben közölt eredmény alátámasztása érdekében a mintát Mössbauerspektroszkópiával vizsgáltuk. A PPy/vas-oxalát ${ }^{57} \mathrm{Fe}$ Mössbauer spektrumát elöször szobahőmérsékleten vettük fel. A legjobb illesztést két dublett adja, ami megfelel a három- és a két vegyértékủ vas ionoknak (4.9. ábra). Az előbbi Mössbauer paraméterei $\delta=0,36(1)$ és $\Delta$ $=0,63(2)$, míg az utóbbié $\delta=1,03(7)$ és $\Delta=2,0(1)$. A spektrum alatti relatív területek aránya 87:13, amely megadja a $\mathrm{Fe}(\mathrm{III})$ és $\mathrm{Fe}(\mathrm{II})$ arányát is. A Fe(III) és $\mathrm{Fe}(\mathrm{II})$ arányából azt feltételezhetjük, hogy a kompozit tartalmaz vegyes vegyértékü komplex aniont, míg a maradék vas $\left[\mathrm{Fe}(\mathrm{III})(\mathrm{ox})_{3}\right]^{3-}$ formában van jelen. Ha a 4.2. táblázatban szereplö elméleti értékeket figyelembe vesszük, akkor az additivitás feltételezésével a következőképpen számolhatunk: a $\mathrm{Fe}$ (III) és a $\mathrm{Fe}$ (II) relatív mennyiségének különbségét megszorozzuk a $\left[\mathrm{Fe}(\mathrm{III})(\mathrm{ox})_{3}\right]^{3-} \Delta \mathrm{m} / \Delta \mathrm{Q}$ értékével, ehhez hozzáadjuk a $\left[\mathrm{Fe}(\mathrm{II}) \mathrm{Fe}(\mathrm{III})(\mathrm{ox})_{3}\right]^{-}$komplex anion relatív mennyiségének és $\Delta \mathrm{m} / \Delta \mathrm{Q}$ értékének a szorzatát, és ezt az összeget normáljuk.

$$
\Delta m / \Delta \mathrm{Q}=\frac{(0,87-0,13) \times 0,390 \mu \mathrm{g} / \mathrm{mC}+0,13 \times 0,585 \mu \mathrm{g} / \mathrm{mC}}{0,87}=0,419 \mu \mathrm{g} / \mathrm{mC}
$$

Ez az eredmény mintegy $15 \%$-kal tér el a kísérletileg meghatározott $0,489 \mu \mathrm{g} / \mathrm{mC}$ értéktöl. 


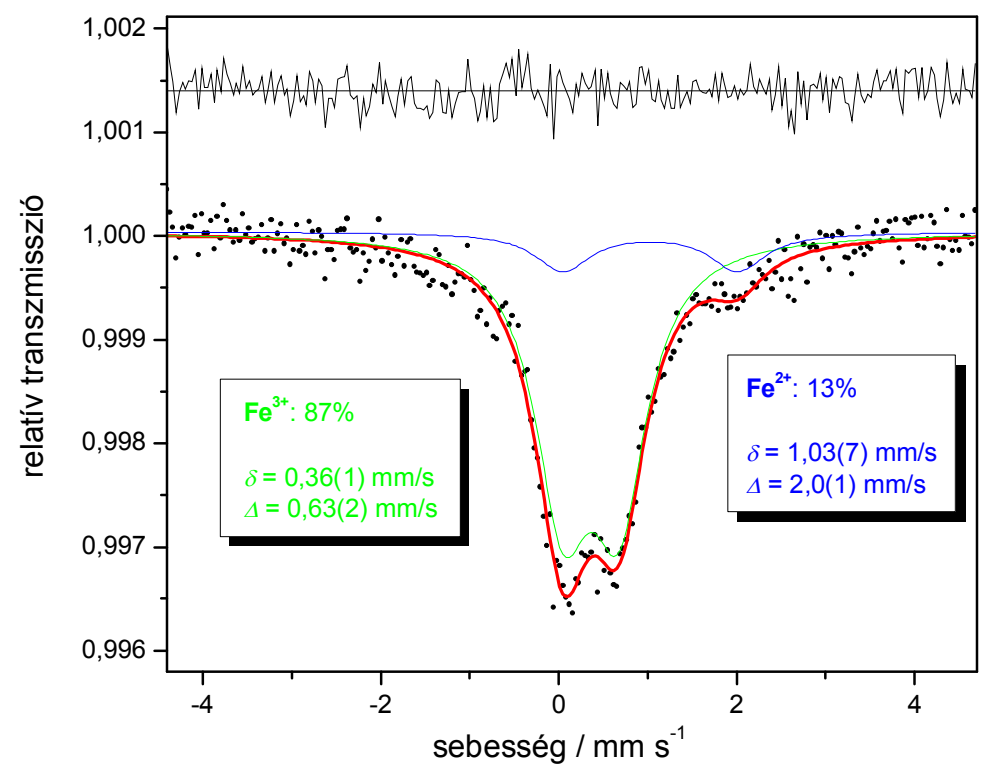

4.9. ábra PPy/vas-oxalát ${ }^{57} \mathrm{Fe}$ Mössbauer spektruma szoba hőmérsékleten

A Mössbauer spektroszkópiás mérést cseppfolyós nitrogén hőmérsékletén is megismételtük (4.10. ábra). A pontosított eredményekből a kompozitban a Fe(III) és a Fe(II) aránya 82:18. Ha a fenti számítást megismételjük, akkor 0,433 $\mu \mathrm{g} / \mathrm{mC}$ kapunk, ami már jól közelíti a kísérletileg meghatározott értéket.

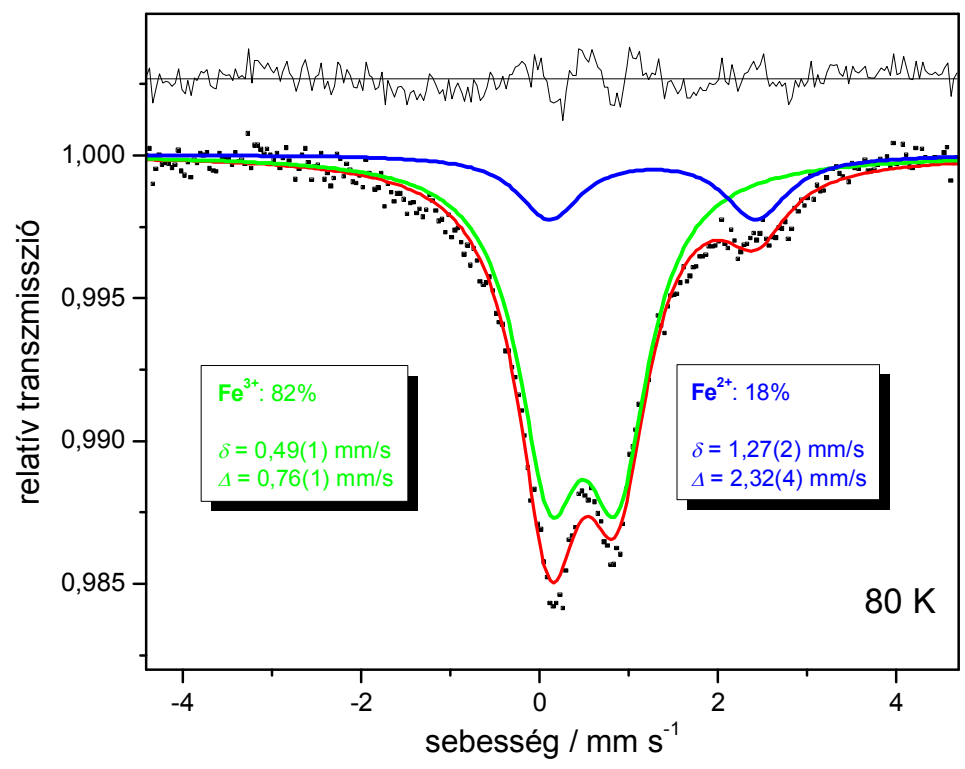

4.10. ábra PPy/vas-oxalát ${ }^{57} \mathrm{Fe}$ Mössbauer spektruma cseppfolyós nitrogén hömérsékletén 


\subsubsection{A PPy/vas-oxalát film spektrális tulajdonságának jellemzése}

Annak érdekében, hogy megismerjük a PPy/vas-oxalát film optikai viselkedését, spektrofotometriás méréseket hajtottunk végre a réteg redoxi átalakításai során. A bemutatott ábrákon egy redukciós (4.11. ábra) és egy oxidációs (4.12 ábra) félciklus alatt felvett UV-Vis spektrumok láthatók. A referencia spektrumot a nyitott áramköri potenciálon vettük fel, így az egymást követő spektrumok az ehhez képest megfigyelt változásokat mutatják. A redukció alatt megfigyelhető spektrális változások egymással párhuzamosan mennek végbe: a $400 \mathrm{~nm}$ nél található semleges forma csúcsának megjelenését a $450 \mathrm{~nm}$ feletti tartomány abszorbanciájának csökkenése követi. A pásztázás oxidációs szakaszán az ellentétes átalakulások egyértelműen megmutatkoznak, az abszorpció a hosszabb hullámhossz tartományban újra növekedni kezd és a $\pi^{*}-\pi$ átalakuláshoz tartozó csúcs lecsökken. Azonban a ciklizálás végén kapott időben utolsó színkép nem azonos a referencia spektrummal, mely oxidáltabb állapothoz tartozik. Ennek hátterében az áll, hogy a teljes redoxi átalakítás megvalósítása a töltésátvitellel összehasonlítva késésben van, mivel egy lassú nem elektrokémiai - deszolvatációhoz kapcsolódó szerkezetváltozási - folyamat is végbemegy [82].

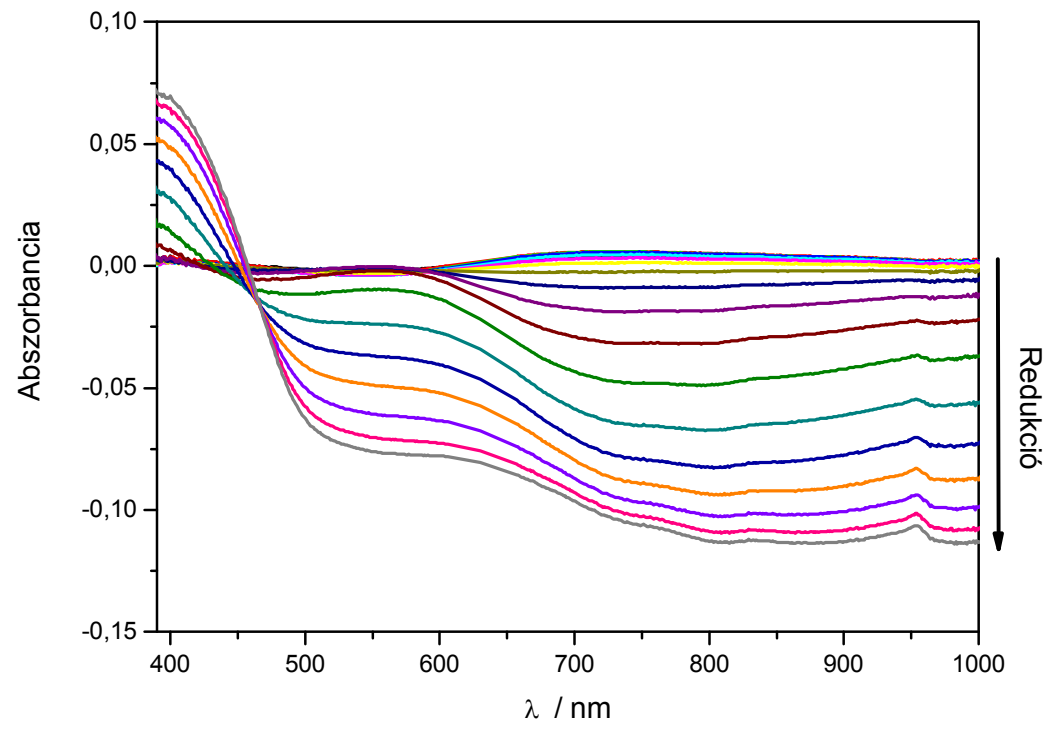

4.11. ábra A PPy/vas-oxalát film spektrális változásai a redukció alatt $0,1 \mathrm{M} \mathrm{Na}_{2} \mathrm{SO}_{4}$ oldatban $25 \mathrm{mV} / \mathrm{s}$ ciklizálási sebesség mellett 


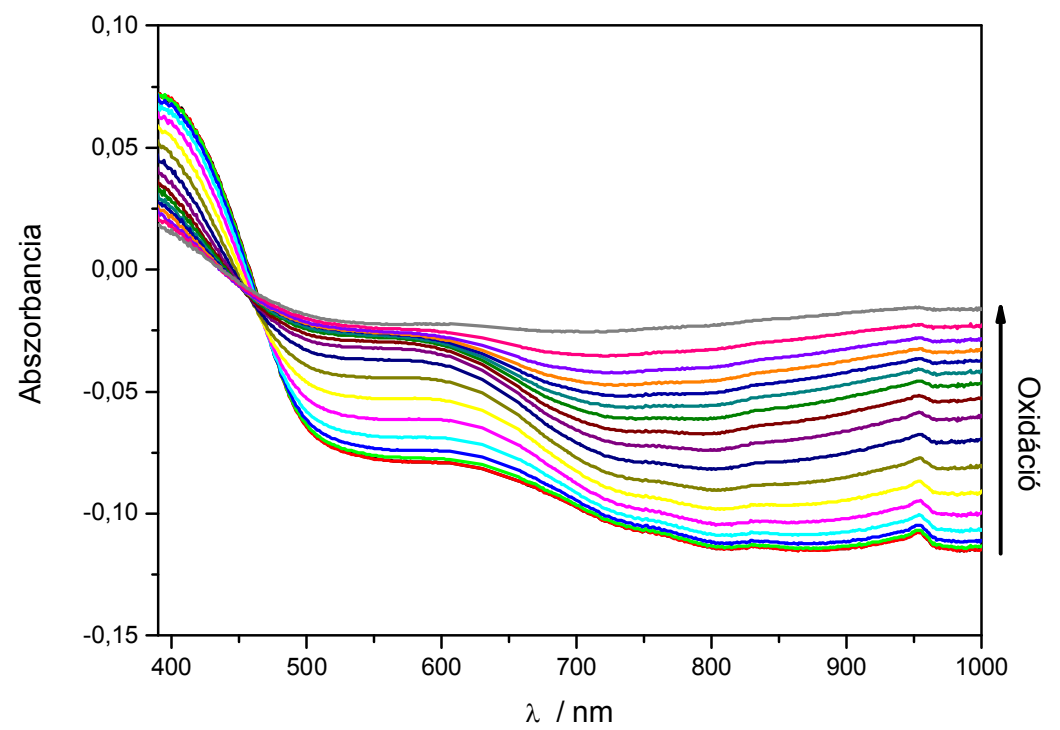

4.12. ábra A PPy/vas-oxalát film spektrális változásai az oxidáció alatt $0,1 \mathrm{M} \mathrm{Na}_{2} \mathrm{SO}_{4}$ oldatban $25 \mathrm{mV} / \mathrm{s}$ ciklizálási sebesség mellett

\subsubsection{A PPy/vas-oxalát film foto-elektokatalitikus tulajdonságának tanulmányozása}

A leválasztott réteget ciklikus voltammetriával vizsgáltuk (4.13. ábra). Jól megfigyelhető, hogy a voltammogram teljes aszimmetriát mutat. A redukciós áramok sokkal

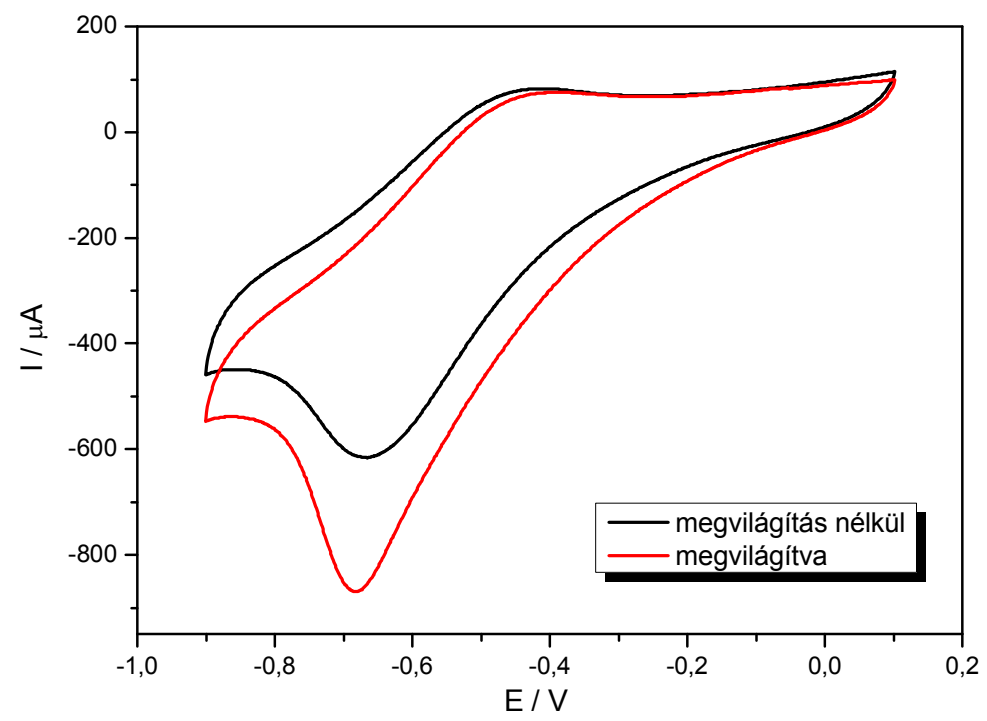

4.13. ábra PPy/vas-oxalát elektród ciklikus voltammogramja megvilágítás nélkül és megvilágítva $0,1 \mathrm{M} \mathrm{Na}_{2} \mathrm{SO}_{4}$ oldatban $25 \mathrm{mV} / \mathrm{s}$ ciklizálási sebesség mellett 
nagyobbak, mint az oxidációsak és ennek következtében az egy ciklus során áthaladt össztöltés is negatív. Ez az eltolódás az oldott oxigén jelenlétéhez köthető. Fehér fénnyel Fiber-Lite A3000 típusú 150 W teljesítményü fényforrás alkalmazásával - történő megvilágítás mellett is regisztráltuk a voltammogramokat, és nagyobb katódos áramokat kaptunk. Így megállapítható, hogy a PPy/vas-oxalát elektród foto-elektrokatalitikus tulajdonságokat mutat. A negatív fotoáram jelzi, hogy az elektronok a kisebbségi töltéshordozók, így a réteg p-típusú félvezető. A katódos fotoáram abban a potenciál tartományban van, ahol a réteg részben redukált állapotban van, de még nem érte el a szigetelő állapotot. 


\subsection{PEDOT/vas-oxalát rétegek elóállítása és jellemzése}

Az előző fejezetben sikeresen elóállított PPy/vas-oxalát elektród analógjaként a PEDOT alapú vas-oxalát szintézisét terveztük megvalósítani. A 3,4-etilén-dioxi-tiofén monomerből előállított PEDOT számos kedvező tulajdonsággal rendelkezik, mint pl. a nagy stabilitás [83], fényáteresztö képesség a polimer vezető állapotában [84], illetve hogy mind nmind p-típusú vezetővé alakítható [85-86].

\subsubsection{A PEDOT/vas-oxalát réteg elektrokémiai előállítása és vizsgálata}

A tiofén-származékok nagy részéből vezető polimert csak vízmentes körülmények között lehet szintetizálni, de a 3,4-etilén-dioxi-tiofén esetében megvalósítható a vizes közegü polimerizáció, mivel a 3-as és a 4-es helyzet védve van az etilén-dioxi csoport által. A PEDOT/vas-oxalát filmet $0,01 \mathrm{M}$ koncentrációjú 3,4-etilén-dioxi-tiofén és telített vas(II)oxalátot tartalmazó vizes oldatból választottuk le egy $2 \mathrm{~cm}^{2}$ Pt elektródra. A szintézist $1,1 \mathrm{~V}$ potenciálon $120 \mathrm{mC} / \mathrm{cm}^{2}$ töltéssürüség mellett valósítottuk meg.

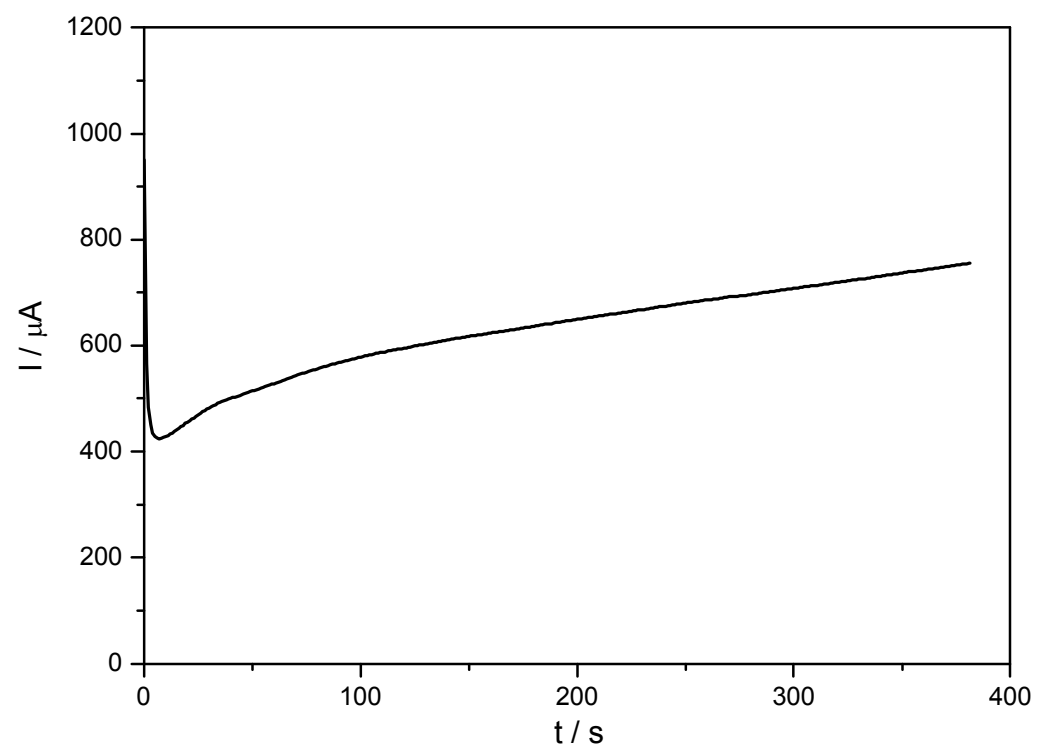

4.14. ábra Az EDOT vas-oxalát jelenlétében történő potenciosztatikus polimerizációja során felvett kronoamperometriás görbe

A 4.14. ábrán az elektrokémiai polimerizáció során rögzített kronoamperometriás görbe látható. Az áram egy rövid tranziens szakasz után hamar stabilizálódik, és lassan, de folyamatosan növekszik a leválasztás alatt. 
Eredmények és értékelésük

A 4.15. ábra a PEDOT/vas-oxalát film voltammetriás viselkedését mutatja be $+0,5 \mathrm{~V}$ és -0,9 V közötti potenciáltartományban különböző ciklizálási sebességek mellett. Megfigyelhető a voltammogramok szimmetriájának torzulása, ami függ a pásztázási sebességtől. A ciklizálási sebesség csökkenésével a ciklusok végén észlelt többlet katódos töltés egyre jelentősebb. Ez könnyen megmagyarázható, mivel a redoxi átalakítás során az oldatban jelenlevő oldott oxigén is oxidálja a réteget, így az elektrokémiai redukció során nagyobb áramok folynak. Az is egyszerủen belátható, hogy minél lassabb a pásztázás, annál nagyobb az oxigén oxidáló hatása. Mivel a voltammetriás áramok abszolút értékei fokozatosan csökkennek a pásztázási sebességgel, ezért további vizsgálatainkhoz az optimálisnak mondható $v=25 \mathrm{mV} / \mathrm{s}$ értéket választottuk.

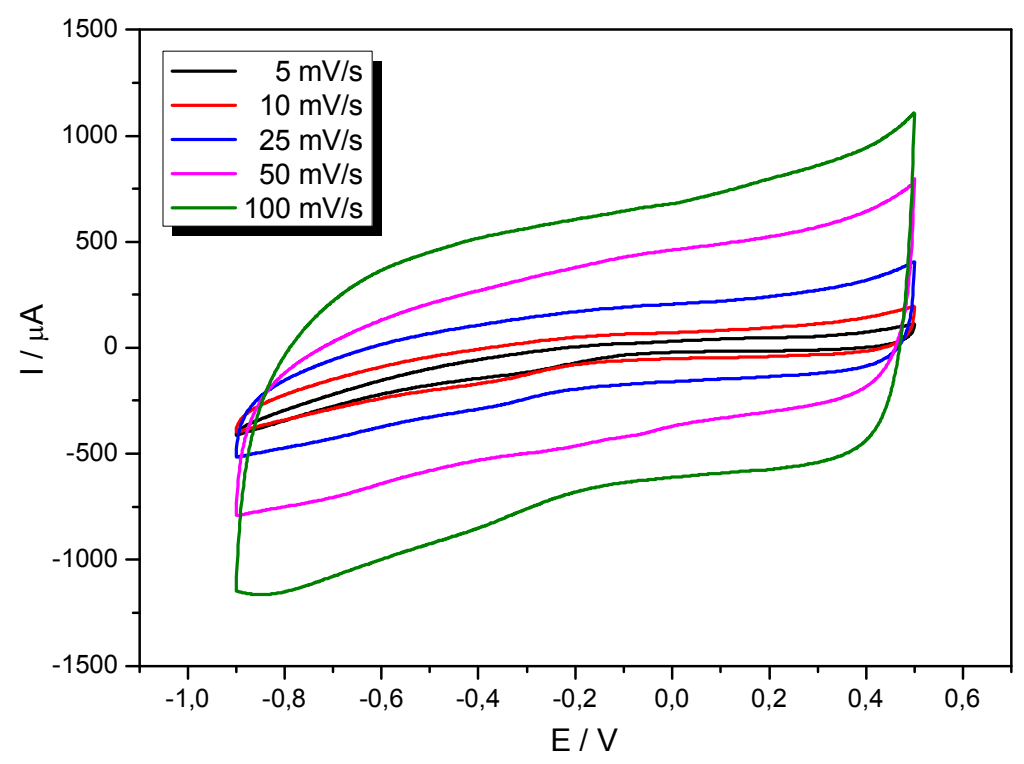

4.15. ábra A PEDOT/vas-oxalát elektród ciklikus voltammogramjai $0,1 \mathrm{M} \mathrm{Na}_{2} \mathrm{SO}_{4}$ oldatban különböző ciklizálási sebesség mellett

Az oldott oxigén koncentrációjának változtatásával befolyásolható a voltammetriás görbék aszimmetriája, amint az a 4.16. ábrán is látható. A redukciós áramok rendre nőnek az oldott oxigén koncentrációjának növelésével.

A különböző oxigén koncentrációknál felvett voltammogramok áramait integráltuk, és a kapott eredmény látható a 4.17. ábrán. A töltés nagyjából lineárisan változik az oldott oxigén koncentrációjának függvényében. Az illesztett egyenes tengelymetszete majdnem zérus, ami 


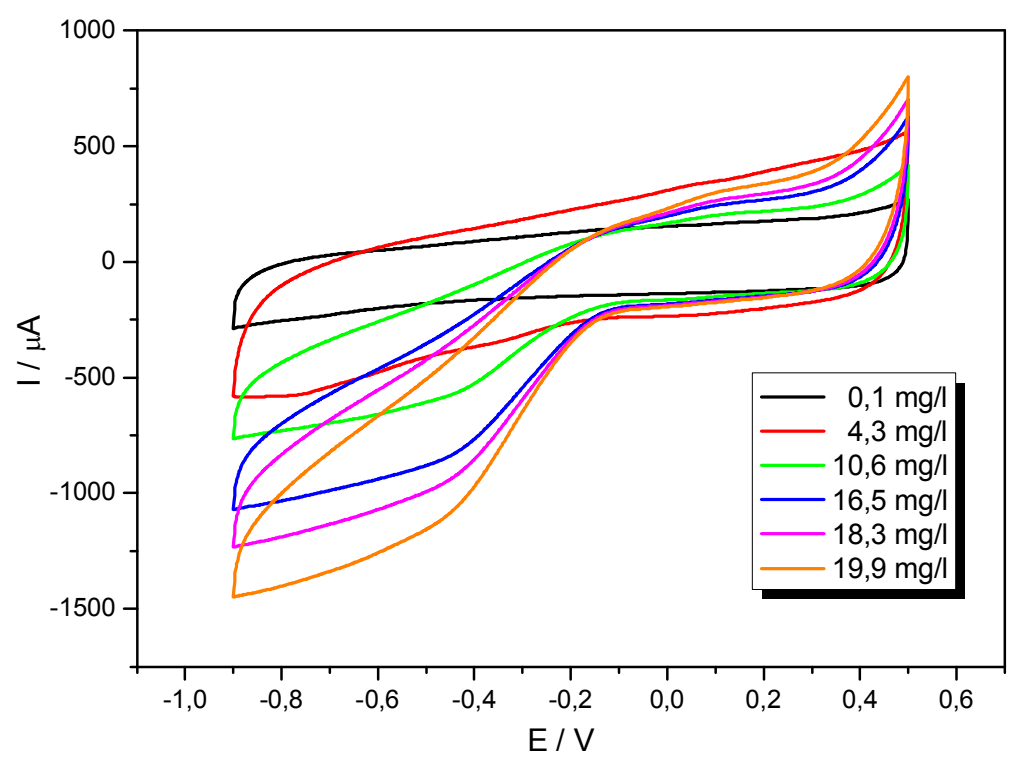

4.16. ábra PEDOT/vas-oxalát elektród voltammetriás görbéi $25 \mathrm{mV} / \mathrm{s}$ ciklizálási sebesség mellett különböző oxigén koncentrációknál

igazolja azon feltevésünket, hogy a katódos töltéstöbblet valóban az oldott oxigén jelenlétéhez köthetö.

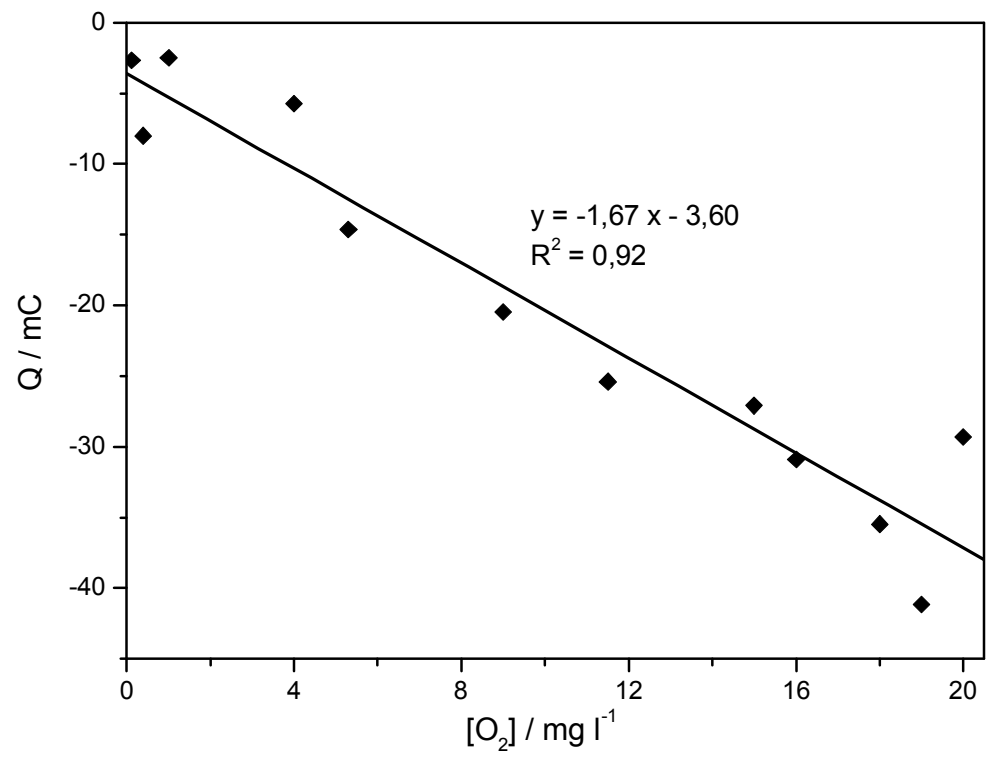

4.17. ábra A 4.16. ábra voltammetriás görbéinek integrálásával kapott töltés és az oxigénkoncentráció kapcsolata 
Eredmények és értékelésük

\subsubsection{A PEDOT/vas-oxalát réteg foto-elektokatalitikus tulajdonságának tanulmányozása}

A PPy/vas-oxalát réteg esetében tapasztalt foto-elektrokatalitikus hatásból kiindulva, úgy döntöttünk, hogy megvizsgáljuk a PEDOT/vas-oxalát filmünk ezen tulajdonságát. A következő ábrákon a foto-elektrokatalitikus hatás látható, amit voltammetriás görbéken keresztül mutatunk be. Ezeken könnyen össze lehet hasonlítani az elektród viselkedését megvilágított és megvilágítás nélküli körülmények között. A méréseket különböző oldott oxigén koncentrációk mellett végeztük el, amik közül néhányat bemutatunk a 4.18., 4.19. és 4.20. ábrákon rendre 5,3 mg/l, 0,4 mg/l és 20,0 mg/l értékeknél. Az 5,3 mg/l-es érték az egyensúlyi koncentráció a levegő és a $0,1 \mathrm{M}$ nátrium-szulfát oldat között $25{ }^{\circ} \mathrm{C}$ hőmérsékleten. Ez az érték egy valamivel kisebb, mint az oxigén oldhatósága tiszta vízben (8,6 mg/l), amit az oxigén Henry-féle állandójából számolhatunk ki. A néhány tized ppm-es tartományt nitrogén gáz oldatunkba történő befúvatásával valósítottuk meg, míg az oldatot oxigén gáz bevezetésével sikerült telítenünk (20 ppm).

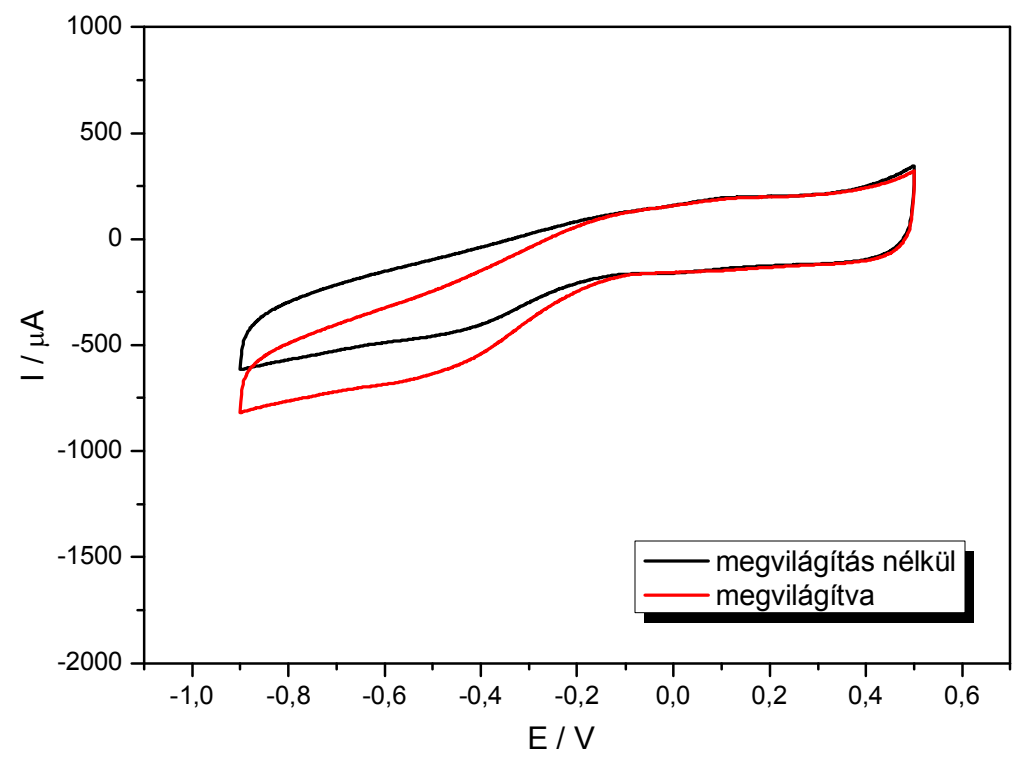

4.18. ábra A PEDOT/vas-oxalát elektród ciklikus voltammogramja $0,1 \mathrm{M} \mathrm{Na}_{2} \mathrm{SO}_{4}$ oldatban $25 \mathrm{mV} / \mathrm{s}$ ciklizálási sebesség és $5,3 \mathrm{mg} / 1$ oxigén koncentráció mellett 


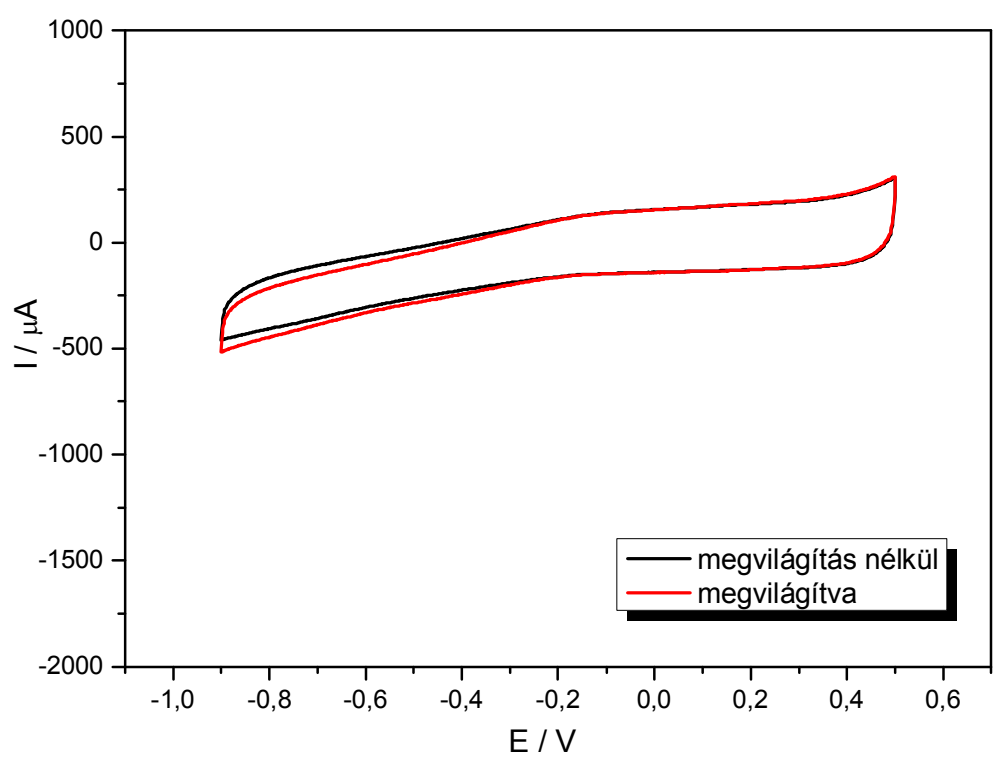

4.19. ábra A PEDOT/vas-oxalát elektród ciklikus voltammogramja $0,1 \mathrm{M} \mathrm{Na}_{2} \mathrm{SO}_{4}$ oldatban $25 \mathrm{mV} / \mathrm{s}$ ciklizálási sebesség és $0,4 \mathrm{mg} / 1$ oxigén koncentráció mellett

$\mathrm{Az}$ eredmények egyértelmüen szemléltetik, hogy az oxigén redukciós áram megvilágítás hatására mindig növekszik, és az áramtöbblet függ az oldat oxigéntartalmától.

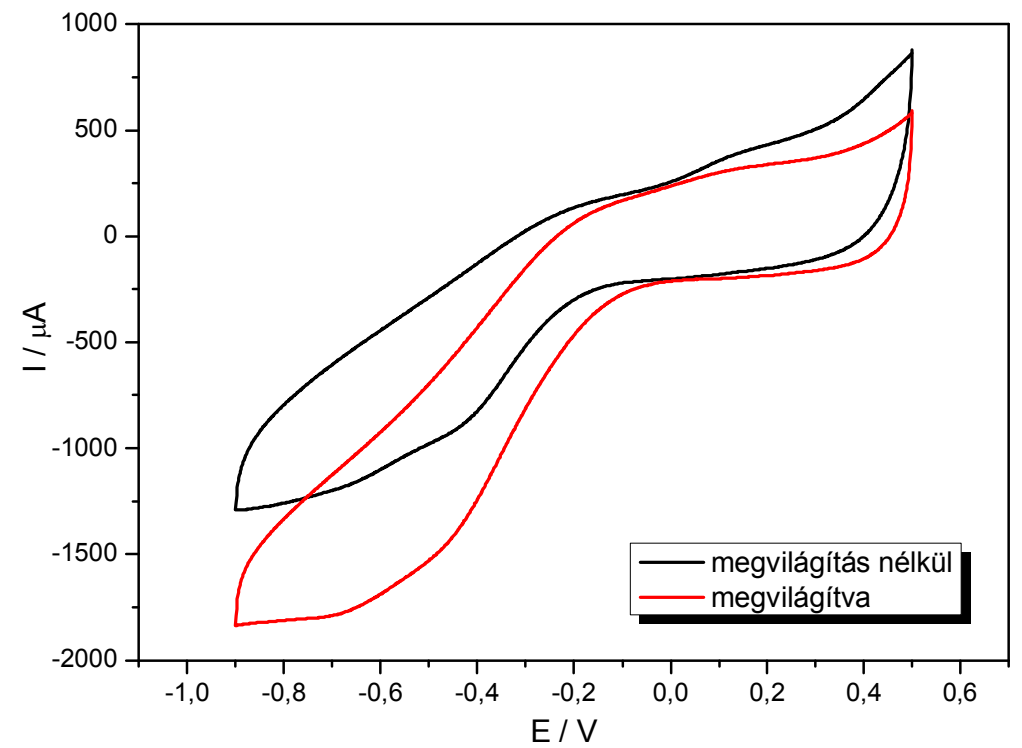

4.20. ábra A PEDOT/vas-oxalát elektród ciklikus voltammogramja $0,1 \mathrm{M} \mathrm{Na}_{2} \mathrm{SO}_{4}$ oldatban $25 \mathrm{mV} / \mathrm{s}$ ciklizálási sebesség és $20,0 \mathrm{mg} / 1$ oxigén koncentráció mellett 
A méréseket elvégeztük az egész $(0,1-20,0 \mathrm{mg} / \mathrm{l})$ oldott oxigén koncentráció tartományban, a 4.21. ábrán bemutatjuk a megvilágítás során felvett ciklikus voltammogramokat. A katódos többletáram monoton növekszik az oldott oxigén mennyiségével.

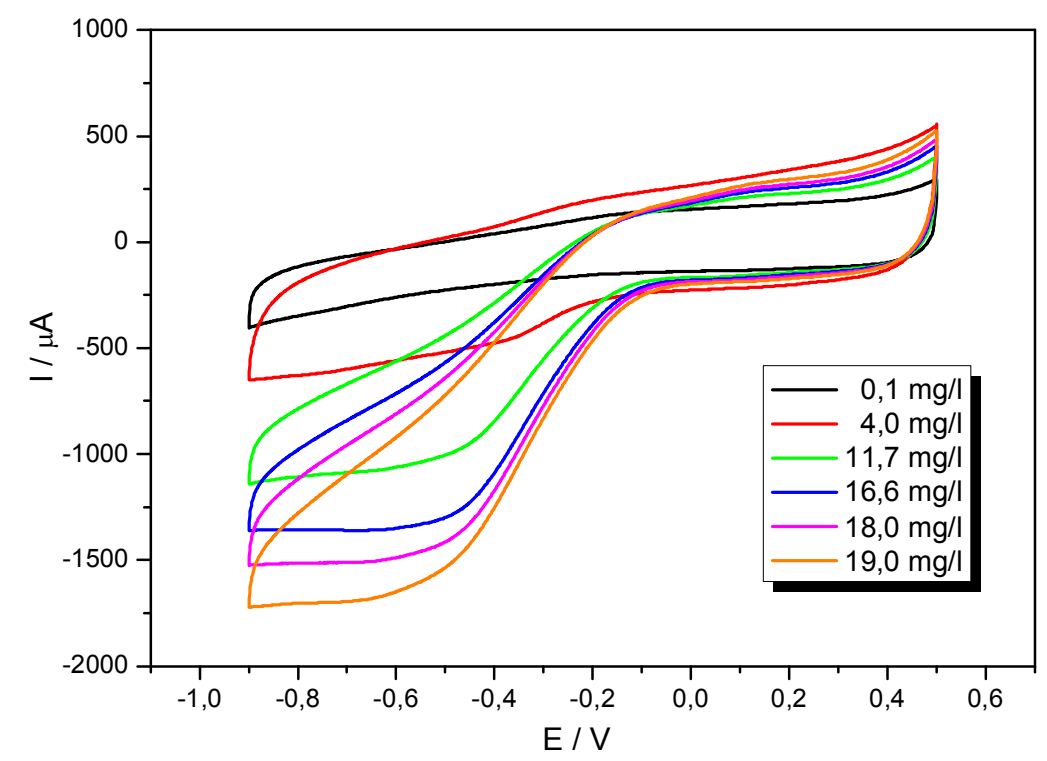

4.21. ábra A megvilágított PEDOT/vas-oxalát elektród voltammetriás görbéi $25 \mathrm{mV} / \mathrm{s}$ ciklizálási sebesség mellett különböző oxigén koncentrációknál

A voltammogramokból az össztöltést kiszámolva, majd ezeket ábrázolva az oxigénkoncentráció függvényében megkapjuk a 4.22. ábrát. Az illesztés során lineáris összefüggést kaptunk, és a tengelymetszet zérushoz közeli értéknek adódott. A zérus tengelymetszet azt jelentené, hogy nincs töltéstöbblet nulla oxigén tartalomnál a megvilágítás hatására. Ez az eredmény megerösítette, hogy a töltéstöbblet, ami szisztematikusan nagyobb, mint a megvilágítás nélküli esetben, az oxigén jelenlétéhez köthető. Ha összehasonlítjuk a 4.17. ábra és a 4.22. ábra lineáris paramétereit, akkor a két meredekség különbsége szembeötlő, megvilágítás esetén a meredekség másfélszer akkora, mint a megvilágítás nélküli esetben, mely megfigyelés összhangban van a 4.21. ábrán bemutatott áramok növekedésével, ami a fotokatalitikus hatást mutatja. 


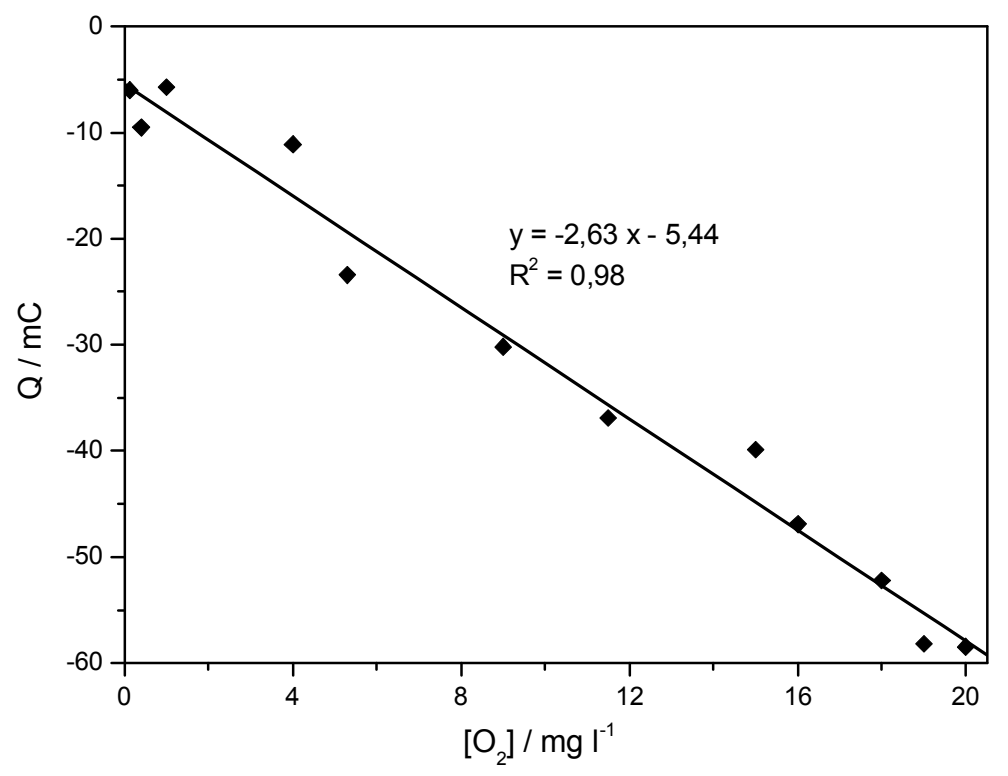

4.22. ábra A 4.21 ábrán megvilágítás mellett kapott voltammetriás görbék integrálásával számolt töltés és az oxigénkoncentráció kapcsolata

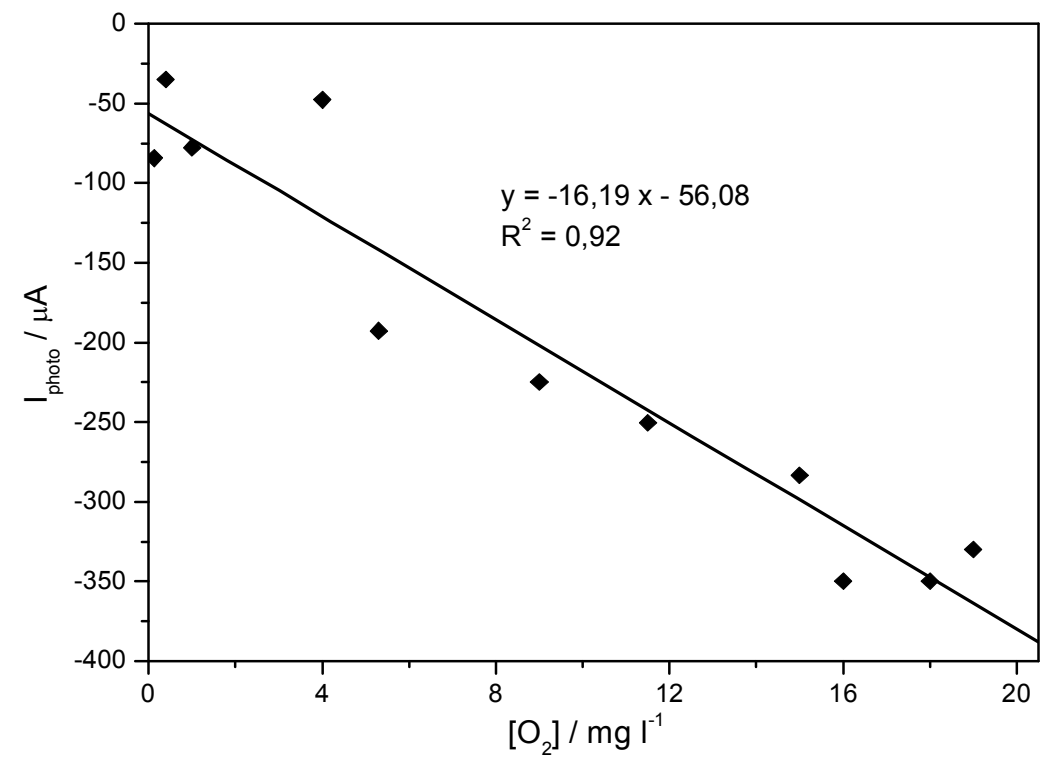

4.23. ábra A különböző oxigénkoncentrációknál kapott fotoáram értékei, amiket a 4.21. ábrán és a 4.16. ábrán -0,75 V potenciálon leolvasott áramok különbségeként kaptunk

A 4.23. ábrán az oxigén koncentráció függvényében ábrázoltuk azon fotoáram értékeket, melyeket a 4.21. ábrán és a 4.16. ábrán $-0,75 \mathrm{~V}$ potenciálon leolvasott áramok különbségeként kaptunk. Az adatok, bár némi szórással, de egyértelmü lineáris korrelációt 
mutatnak a fotoáram és az oldott oxigén koncentráció között. A tengelymetszet $-56 \mu \mathrm{A}$, ami kifejezi, hogy ez az a fotoáram, amikor nincs oxigén az oldatban. Ha ez a tengelymetszet valós és nem az egyes mérési pontok szórásából fakadó mesterséges jelenség, akkor ez felel meg a PEDOT réteg saját redukciója fotoáramának. Minthogy a 4.23. ábra adatai dinamikus mérésekből erednek, ennek folytán ezek az áramok mind az oldott oxigén, mind a polimer film redukciójából mint két párhuzamos folyamatból származnak.

Annak érdekében, hogy megbízhatóbb információt kapjunk a fotoáramról és annak az oxigén redukciós folyamatában betöltött szerepéröl, stacionárius méréseket végeztünk. A kísérleteinket úgy hajtottuk végre, hogy a potenciált $-0,75 \mathrm{~V}$-on tartottuk, és $250 \mathrm{~s}$ után, mikorra már stabilizálódott az áram, megvilágítottuk az elektródunkat. Megvártuk, hogy az áram beálljon egy állandó értékre, majd újabb $250 \mathrm{~s}$ elteltével kikapcsoltuk a fényforrást. A fotoáramot az előbb említett két időpillanatban leolvasott, stabilizálódott áram különbségeként határoztuk meg. Egy ilyen mérési görbét mutatunk be a 4.24. ábrán, ahol arra a fontos tényre is felhívjuk a figyelmet, hogy a megvilágítás kikapcsolása után az áram visszatér a kezdetben beállt értékre. A megvilágítás többszöri be- és kikapcsolásával a fotoáramok 5-6 \%-os kísérleti hibán belül reprodukálódtak.

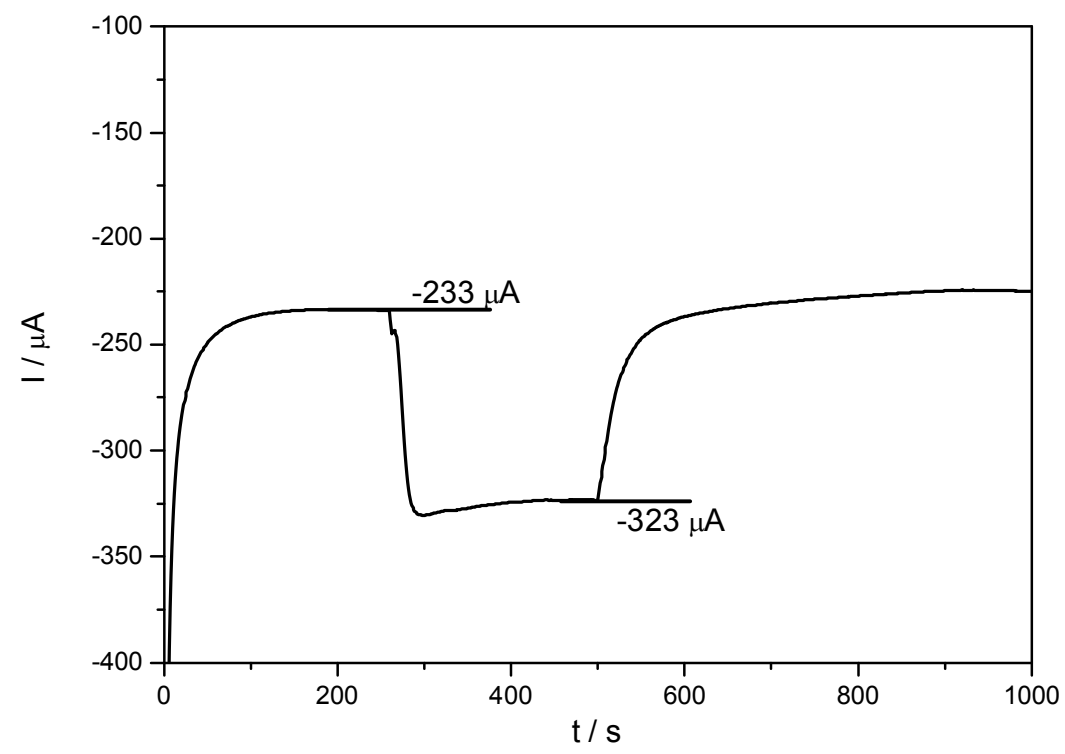

4.24. ábra $\mathrm{A}-0,75 \mathrm{~V}$ potenciálon mért kronoamperometriás görbe $250 \mathrm{~s}-$ ig megvilágítás nélkül, majd 500 s-ig megvilágítva 4,26 mg/l oxigén koncentrációnál 
Eredmények és értékelésük

A stacionárius fotoáramot meghatározó méréseinket az oldat különböző oxigénkoncentrációinál is elvégeztük, és így megkaptuk a stacionárius kalibrációs görbénket (4.25. ábra). Ahogyan az feltételezhető volt, az adatok sokkal jobb lineáris illesztést mutatnak, mint a dinamikus mérésekből meghatározott kalibrációs görbe esetén. Másfelől várakozásainknak megfelelően az illesztett egyenes tengelymetszete sokkal kisebb - mintegy $14 \mu \mathrm{A}$-, mely érték kifejezi, hogy stacionárius körülmények között sokkal kisebb a PEDOT redukciójának hozzájárulása a teljes fotoáramhoz.

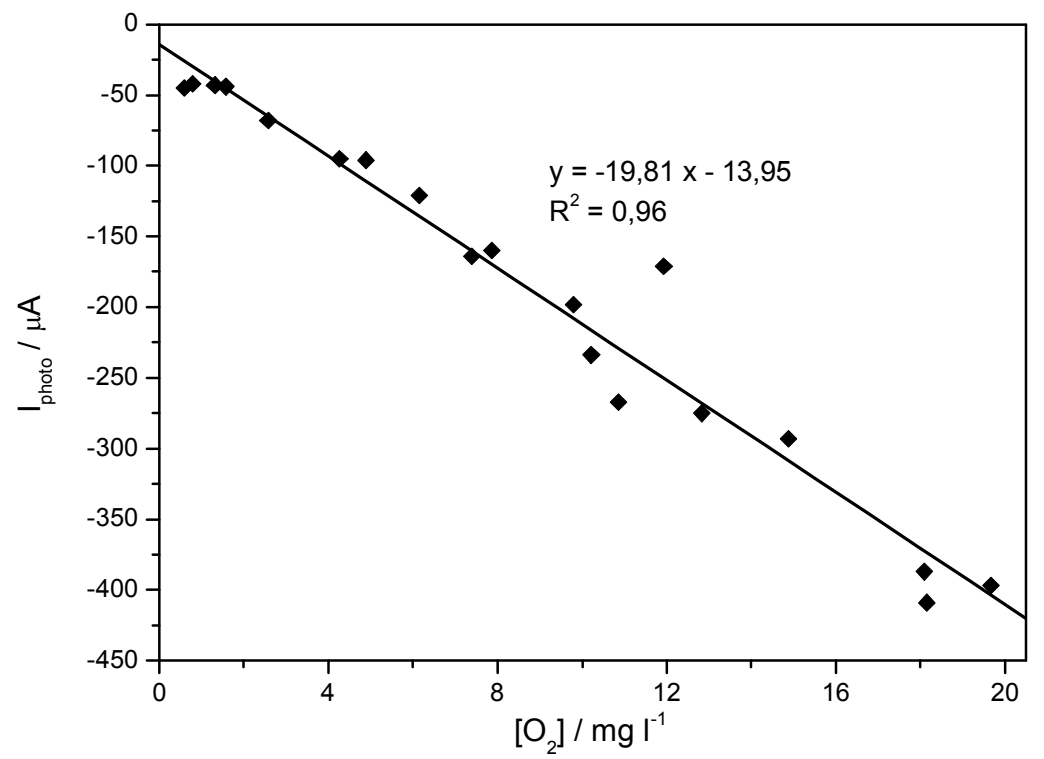

4.25. ábra A kronoamperometriás mérésekböl kapott stacionárius fotoáramok az oldott oxigén koncentrációjának függvényében

A fény intenzitásának hatását a 4.26. ábra szemlélteti, ahol a különböző megvilágítási intenzitásoknál mért fotoáramok láthatók. A görbe telítési jellegü, a nagyobb relatív intenzitásoknál a fotoáram egy határértékhez tart. (Zárójelben jegyzem meg, hogy minden kísérletnél a maximális fény intenzitást alkalmaztuk).

Egy lehetséges szenzor esetében az élettartam is egy fontos szempont. Ezért megvizsgáltuk a rétegünk degradációját folyamatos megvilágítás hatására. Ezt úgy valósítottuk meg, hogy felvettük a rétegünk ciklikus voltammogramjait megvilágítás nélkül egy 24 órás folyamatos megvilágítás előtt és után (4.27. ábra), majd ezeket hasonlítottuk össze oly módon, hogy integrálással kiszámoltuk az áthaladó töltéseket az oxidációs folyamat során. Az ezekre kapott értékekből (10,8 mC és 9,88 mC) Megállapítottuk, hogy az oxidációs töltés 
csökkenése csupán 8,5 \%, amiből arra következtethetünk, hogy a rétegünk stabilnak mondható, és a foto-degradáció elhanyagolható.

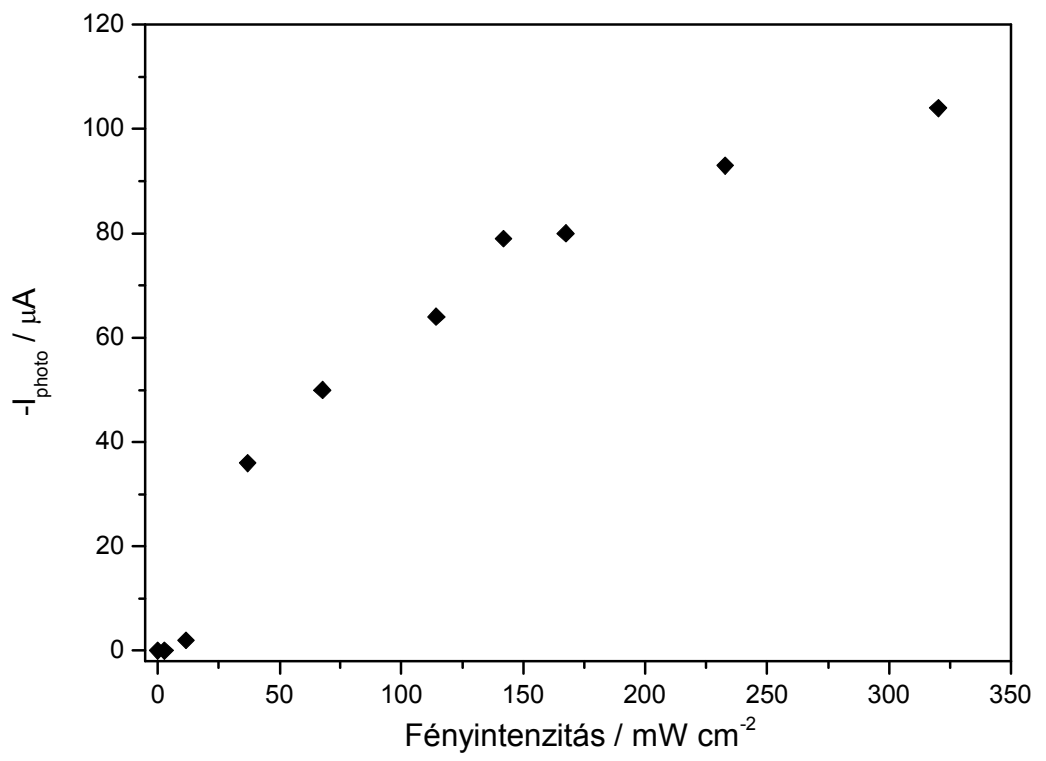

4.26. ábra A megvilágítás intenzitásának hatása az oxigén redukciós fotoáramára $5,2 \mathrm{mg} / 1$ oxigénkoncentráció mellett

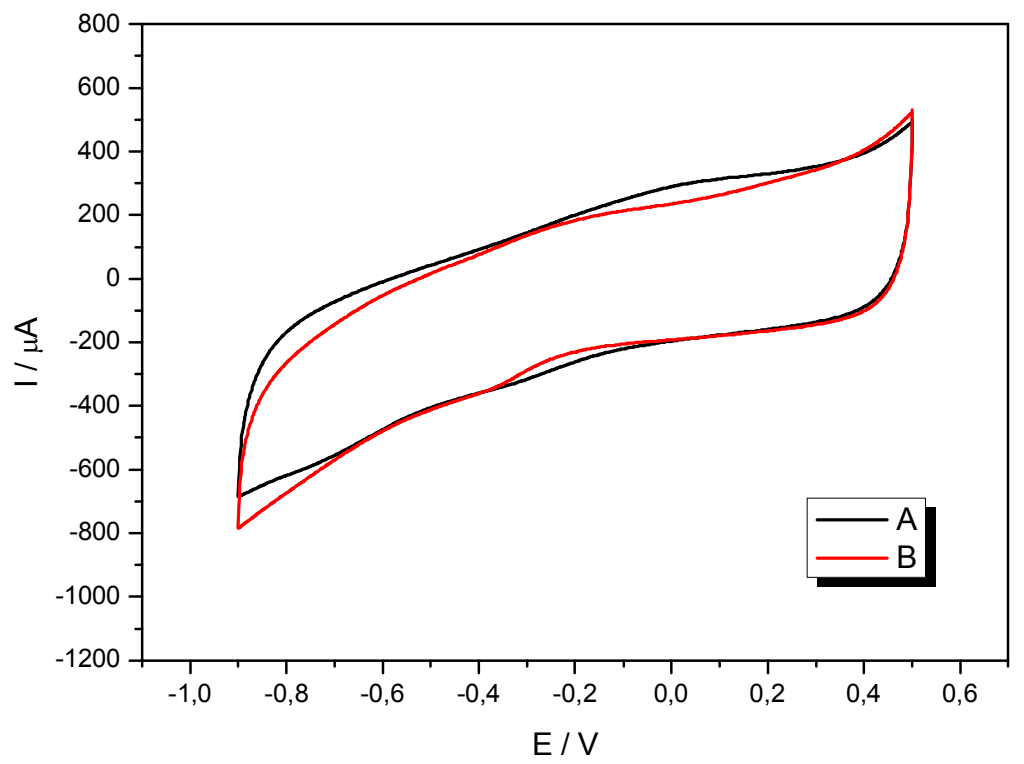

4.27. ábra A PEDOT/vas-oxalát elektród ciklikus voltammogramjai $0,1 \mathrm{M} \mathrm{Na}_{2} \mathrm{SO}_{4}$ oldatban $25 \mathrm{mV} / \mathrm{s}$ ciklizálási sebesség mellett megvilágítás nélkül 24 órás folyamatos megvilágítás előtt (A) illetve után (B) 
Eredmények és értékelésük

Egy potenciális érzékelő kifejlesztésének megalapozásánál a lehetséges zavaró hatások tanulmányozásáról is szót kell ejteni, és a bemutatott módszer szelektivitását is szükséges vizsgálni. A legtöbb természetes vízforrás tartalmaz redukálható anionokat, mint a nitrát, hidrogén-karbonát és szulfát, ezért megvizsgáltuk az elektródunk és módszerünk teljesítőképességét ezen anionok jelenlétében. Az eredményeket a 4.3. táblázatban foglaltuk össze, melyből leszürhető, hogy a fotoáramok összemérhető körülmények között a kísérleti hibán belül megegyeznek. Így ezek az anionok közül egyik sem zavarja az oldott oxigén fotoelektrokémiai meghatározását.

4.3. táblázat Néhány redukálható aniont tartalmazó oldatokban mért stacionárius fotoáramok $5,2 \mathrm{mg} / 1$ oxigén koncentráció mellett

\begin{tabular}{|c|c|c|}
\hline Anion & Koncentráció $(\mathrm{mg} / \mathrm{l})$ & Fotoáram $(\mu \mathrm{A})$ \\
\hline Nitrát & 60 & 112 \\
\hline Hidrogén-karbonát & 60 & 117 \\
\hline Szulfát & 60 & 115 \\
\hline
\end{tabular}

\subsubsection{A PEDOT/vas-oxalát réteg spektro-elektrokémiai vizsgálata}

Annak érdekében, hogy megismerjük a PEDOT/vas-oxalát film redoxi átalakítások során mutatott optikai viselkedését, spektrofotometriás méréseket végeztünk. A ciklikus voltammetriás görbéket $0,1 \mathrm{M} \mathrm{Na}_{2} \mathrm{SO}_{4}$ oldatban $25 \mathrm{mV} / \mathrm{s}$ ciklizálási sebesség mellett vettük

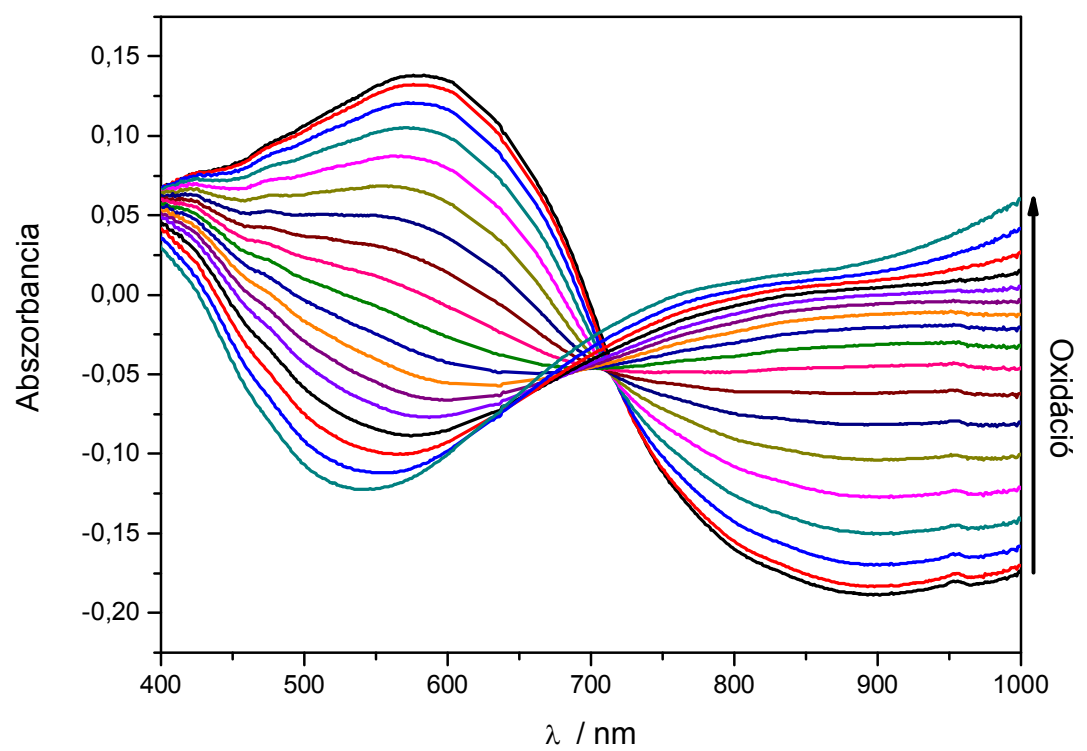

4.28. ábra A PEDOT/vas-oxalát film spektrális változásai az oxidáció alatt 
Eredmények és értékelésük

fel. A referenciaspektrumot most is a nyitott áramköri potenciálon rögzítettük. A spektrumokat egy oxidációs (4.28. ábra) és egy redukciós (4.29. ábra) félciklus alatt regisztráltuk, melyekből látható, hogy a semleges rétegnek $580 \mathrm{~nm}$-nél van abszorbancia maximuma. Ez a semleges forma alakul át az oxidáció alatt, és így megjelenik egy új abszorpciós csúcs az alacsonyabb energiájú tartományban. A redukció végére visszakapjuk a kezdeti színképünket, amely tény bizonyítja, hogy az átalakítás reverzibilis.

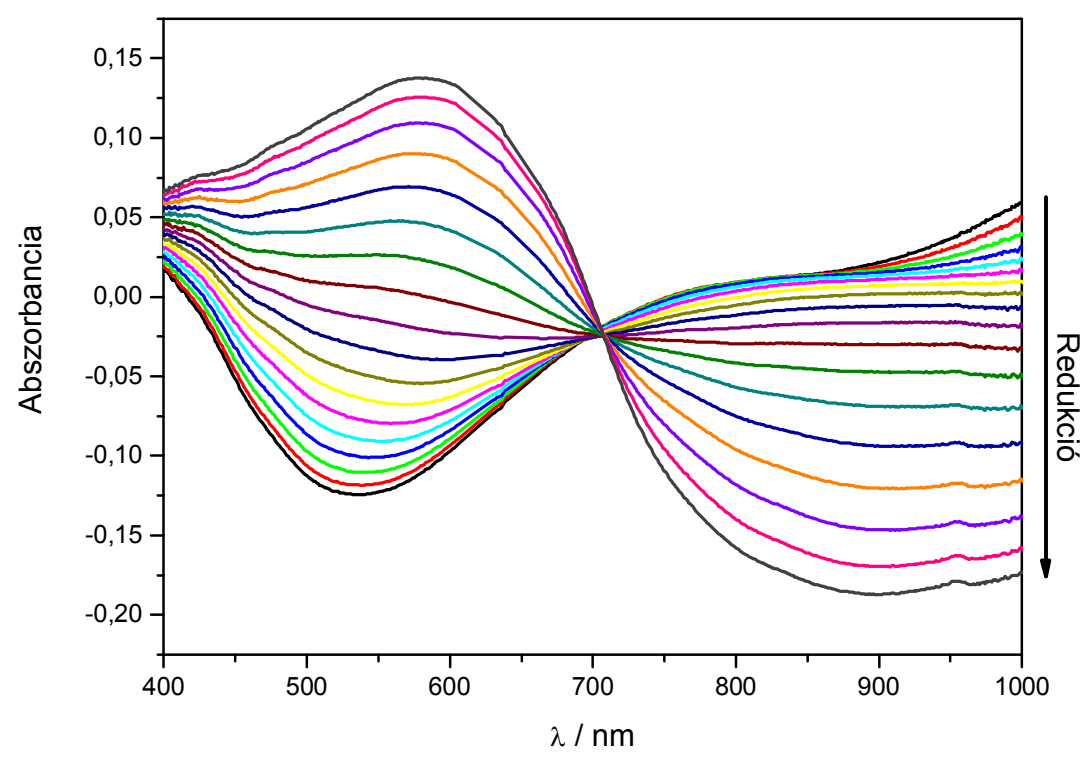

4.29. ábra A PEDOT/vas-oxalát film spektrális változásai a redukció alatt

Oxigén jelenlétében a rétegünk vegyes oxidációs állapotban van, és ezek a különböző állapotformák eltérő hullámhosszokon nyelnek el. Azzal a céllal, hogy megtaláljuk az összefüggést a fotokatalitikus hatás és a PEDOT/vas-oxalát film optikai viselkedése között, azaz hogy megállapíthassuk, melyik forma fényelnyelése eredményezi a fotokatalitikus hatást -, megmértük a stacionárius fotoáramokat egyensúlyi oxigénkoncentráció mellett különbözö színszürőket használva. A színszürők spektrumai a 4.30. ábrán láthatók. A kapott eredményeket a 4.4. táblázatban foglaltuk össze, ahol a megadott hullámhossz azt jelenti, hogy a szürő ezen hullámhosszküszöb-érték feletti tartományban engedi át a fényt. Azokban az esetekben, amikor olyan színszürőket használtunk, melyek csak az ultraibolya tartományban nyeltek el, ezek nem voltak hatással a fotoáramra. Ugyanez érvényes az $570 \mathrm{~nm}$ hullámhossz alatt elnyelő szürők esetében is. A $640 \mathrm{~nm}$-nél nagyobb energiájú fényt kiiktató színszürő képviseli azt a küszöböt, amikor a fotoáram elkezd csökkenni. Azok a szürők, melyek csak 
Eredmények és értékelésük

$720 \mathrm{~nm}$ felett engednek át, kioltják a fotoáramot. Mivel a rétegünk optikai spektrumának kvázi izobesztikus pontja $700 \mathrm{~nm}$ körül van (4.29. ábra), az adatokból egyértelműen megállapítható, hogy a fotokatalitikus hatás a polimer film semleges formájának gerjesztésével áll kapcsolatban.

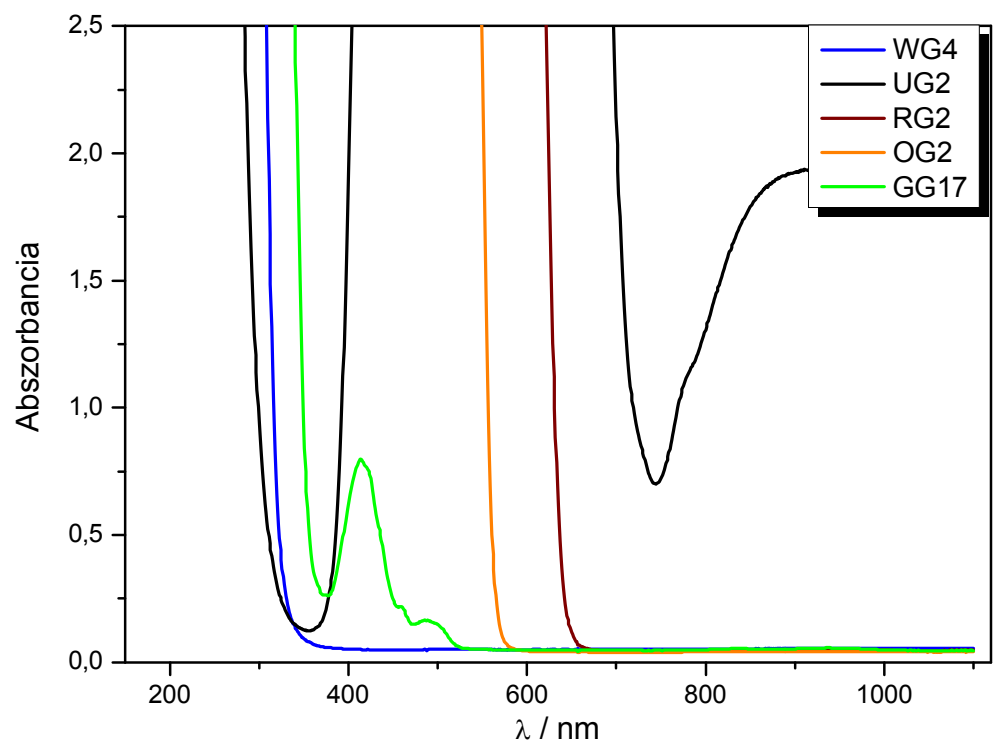

4.30. ábra A használt optikai szürők abszorbanciaspektrumai

4.4. táblázat A különböző színszürők levágási hullámhossz értékei és a mért fotoáramok (összehasonlításként megadtuk a színszürő nélkül detektált fotoáramot is)

\begin{tabular}{|c|c|c|}
\hline Színszürö típusa & $\lambda(\mathrm{nm})$ & Fotoáram $(\mu \mathrm{A})$ \\
\hline WG4 & 330 & 57 \\
\hline GG17 & 420 & 60 \\
\hline OG2 & 570 & 57 \\
\hline RG2 & 640 & 45 \\
\hline UG2 & 720 & 0 \\
\hline Színszürő nélkül & & 65 \\
\hline
\end{tabular}




\subsubsection{A PEDOT/vas-oxalát oxigén redukciójának kinetikai vizsgálata}

Az oxigén katódos redukciójának mechanizmusára két lehetséges utat szoktak megadni attól függően, mi a folyamat terméke. Ennek megfelelően szoktak beszélni kételektronos folyamatról, melynek terméke hidrogén-peroxid, illetve négyelektronos mechanizmusról, amikor az oxigén vízzé redukálódik. Az oxigénredukció fotokatalitikus vizsgálata során leírt sebességnövekedés (ld. 4.3.2. fejezet) felvetette annak a lehetőségét, hogy a fotokatalitikus hatás esetleg a kételektronos folyamatnak a négy elektron átmenetével járó variánssá történő kiegészülése.

Ennek eldöntésére forgó korongelektródos méréseket is elvégeztünk az oxigénredukció töltésszámának meghatározásának céljából. Mint ismeretes, az elektronátmenetek száma meghatározható a Koutecky-Levich összefüggés felhasználásával a katódos redukciós görbéken mért áram fordulatszámtól való függéséből [87]. Méréseinket nyolc különböző fordulatszám értéknél (200 - 2000 rpm tartományban) végeztük el az oxigénnel telített $0,1 \mathrm{M}$ $\mathrm{Na}_{2} \mathrm{SO}_{4}$ oldatban $10 \mathrm{mV} / \mathrm{s}$ ciklizálási sebesség mellett $+0,2 \quad \mathrm{~V}$ és $-0,9 \mathrm{~V}$ közötti potenciáltartományban. A felvett voltammetriás görbéket a 4.31. ábrán mutatjuk be.

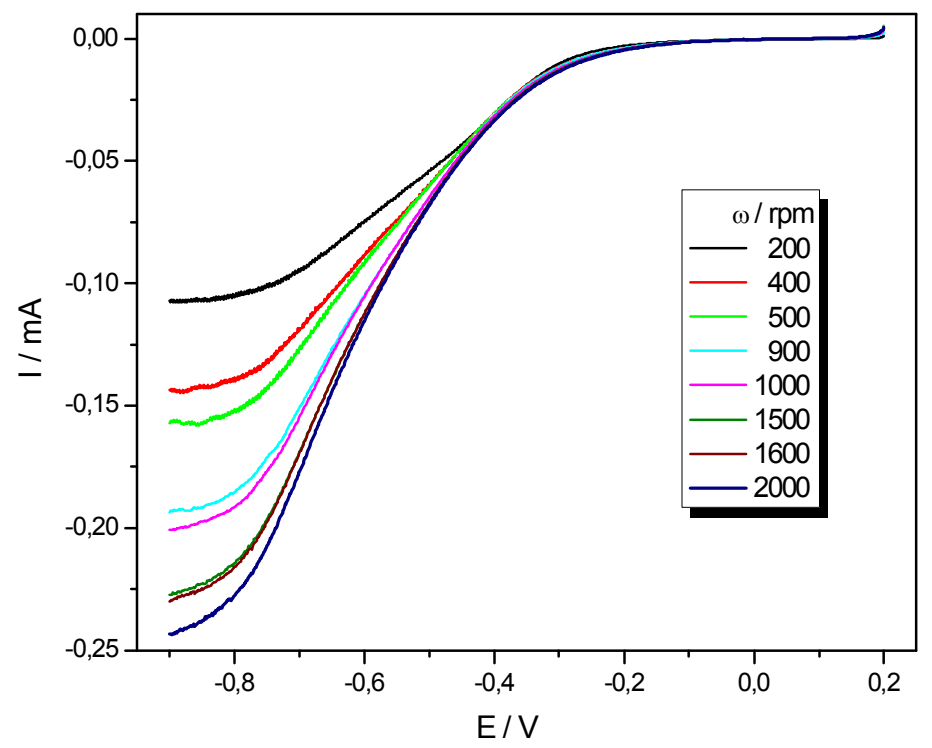

4.31. ábra. A PEDOT/vas-oxalát réteg oxigén redukciójának vizsgálata forgó korongelektródon 
A kapott áramok értékét három különböző potenciálon leolvasva és ezeket ábrázolva a fordulatszám négyzetgyökének reciprokának függvényében, megkaptuk a Koutecky-Levich görbéket, amik a 4.32. ábrán láthatók.

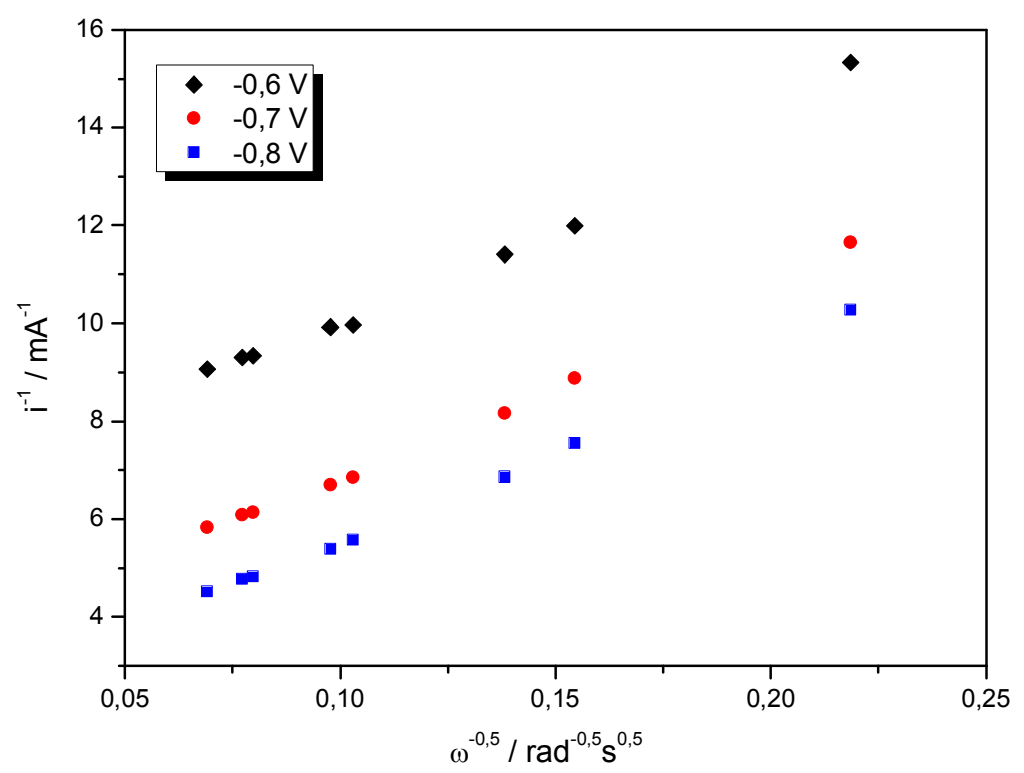

4.32. A PEDOT/vas-oxalát elektródon történő oxigén redukciójának Koutecky-Levich görbéi $0,1 \mathrm{M} \mathrm{Na}_{2} \mathrm{SO}_{4}$ oldatban különböző potenciál értékeknél

A Koutecky-Levich egyenlet felhasználásával kapott $\mathrm{n}$ értékeket a 4.5. táblázat tartalmazza. Az egyenletbe behelyettesített állandók [88-89]:

$\begin{array}{lll}\mathrm{F} & \text { Faraday-állandó } & 96485 \mathrm{C} / \mathrm{mol} \\ \mathrm{A} & \text { az elektród területe } & 0,0707 \mathrm{~cm}^{2} \\ \mathrm{D}_{\mathrm{O}_{2}} & \text { az oxigén diffúziós együttható } & 1,8 \times 10^{-5} \mathrm{~cm}^{2} / \mathrm{s} \\ v & \text { kinematikus viszkozitás } & 0,01 \mathrm{~cm}^{2} / \mathrm{s} \\ \mathrm{C}_{\mathrm{O}_{2}} & \text { az oxigén telítési koncentrációja } & 1,13 \times 10^{-6} \mathrm{~mol} / \mathrm{cm}^{3} \\ \omega & \text { forgási sebesség } & 200-2000 \mathrm{rpm} \\ \mathrm{I}_{\mathrm{k}} & \quad \text { kinetikus áram } & \\ \mathrm{I}_{\mathrm{d}} & \quad \text { diffúziós áram } \\ \frac{1}{I}=\frac{1}{I_{k}}+\frac{1}{I_{d}}=\frac{1}{n \times F \times A \times k \times C_{O_{2}}^{b}}-\frac{1}{0,62 \times n \times F \times A \times D_{O_{2}}^{2 / 3} v^{-1 / 6} \times C_{O_{2}}^{b} \times \omega^{1 / 2}}\end{array}$

4.5. táblázat

\begin{tabular}{|c|c|}
\hline$E(V)$ & $n$ \\
\hline$-0,6$ & 3,37 \\
\hline$-0,7$ & 3,58 \\
\hline$-0,8$ & 3,62 \\
\hline
\end{tabular}


Megállapíthatjuk a kapott eredményeink alapján, ahol n értéke 3,5 körülinek adódott, hogy a PEDOT/vas-oxalát elektródon az oxigén redukció megvilágítás nélkül is a négyelektronos mechanizmust közelíti. Így a megvilágítás korábban ismertetett hatása semmiképpen nem jelent mechanizmusváltást, csupán a végbemenő folyamatok valamelyik lépésének katalízisét. Mivel a hidrogén-peroxid bomlásának katalízisében a vasionok szerepe köztudott, feltételezésünk szerint ez a lépés a hidrogén-peroxid redukciója. Mindezek alapján a fotokatalitikus hatásra irányuló vizsgálatainkat kiterjesztettük a magnetit nanorészecskéket tartalmazó polimer kompozitra, melynek egyéb tulajdonságait kutatócsoportunk már korábban részletesen vizsgálta. 
4.4. Mágneses tulajdonságú PPy réteg szintézise és jellemzése

A kutatócsoportunkban korábban elóállított magnetit tartalmú polipirrol elektród jellemzése és katalitikus aktivitásának vizsgálata az oxigén redukciós és a hidrogén-peroxid dekompozíciós reakciókban már megtörtént [90]. Ezeknek az eredményeknek a tükrében tovább kívántuk tanulmányozni a PPy/magnetit elektród tulajdonságait különös tekintettel ezeknek fotokatalitikus vonatkozásait.

\subsubsection{PPy/PTO/magnetit és PPy/PTO rétegek elóállítása}

A ,tiszta” polimert és a polipirrol/magnetit hibridet galvanosztatikusan választottuk le platina elektródra $3 \mathrm{~mA} / \mathrm{cm}^{2}$ áramsürüség mellett. A polimerizációs oldat, melyből a mágneses hibridet szintetizáltuk, 0,1 M koncentrációban tartalmazott pirrolt, 0,05 M kálium-tetraoxalát [91] elektrolitot és $10 \mathrm{~g} / \mathrm{l}$-es volt a magnetit tartalma. Az összehasonlítási alapként elóállított PPy/PTO réteget az előbbivel azonos összetételü, de magnetitet nem tartalmazó oldatból állítottuk elő.

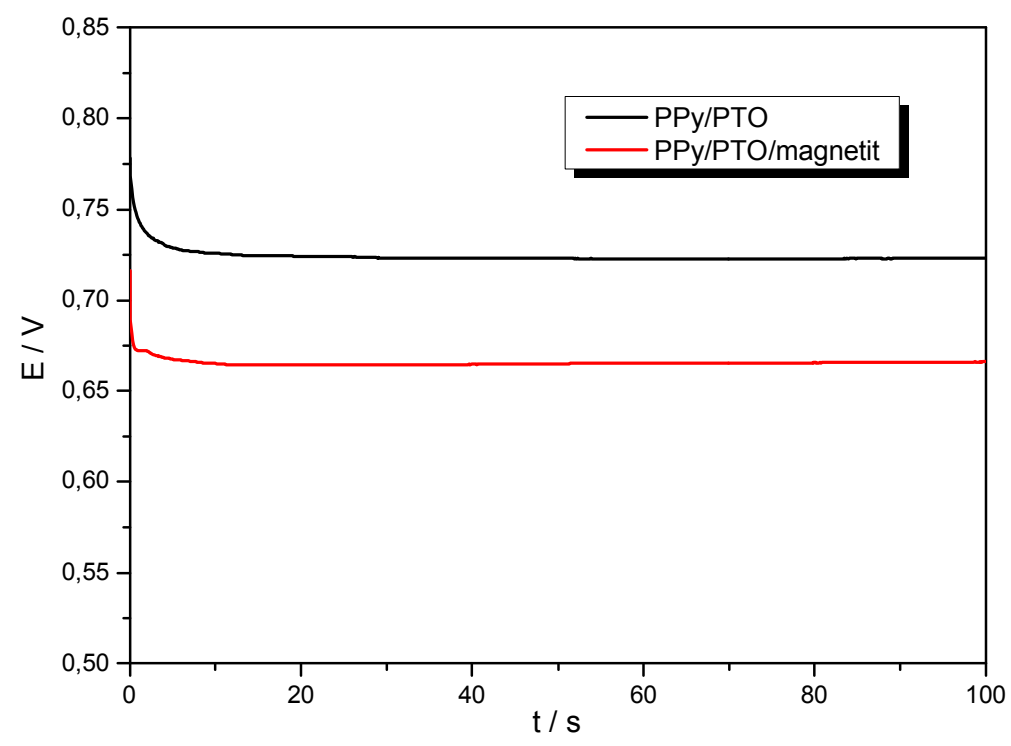

4.33. ábra A kronopotenciometriás görbéken a pirrol kálium-tetraoxalát illetve a pirrol kálium-tetraoxalát és magnetit jelenlétében történő polimerizációja látható

A 4.33. ábrán a kronopotenciometriás görbéket mutatjuk be, a két polimerizációs görbe lefutása hasonló. Tisztán látható, hogy az elején egy rövid tranziens szakasz kivételével az egész leválasztás során a mért potenciál állandó, ami arra utal, hogy a polimerréteg 
növekedése akadálytalan. Ezen túlmenően azt a tényt is fontos megjegyezni, hogy a hibrid esetében kevésbé pozitív potenciálon történik a polimerizáció, ami vélhetőleg a magnetit nanorészecskék beépülése mellett biztosított módosuló felületnek köszönhető.

\subsubsection{PPy/PTO/magnetit és PPy/PTO rétegek elektrokémiai viselkedése}

Annak érdekében, hogy tanulmányozzuk a hibrid elektródunk elektrokémiai viselkedését, ciklikus voltammogramokat vettünk fel különböző ciklizálási sebességek mellett nitrogénnel telített foszfát-pufferben. A 4.34. ábrán a tiszta polimer és a kompozit elektród redoxi átalakításait mutatjuk be. A hibrid elektród esetében jelentős elektroaktivitás-többlet mutatkozik, ami a beépült vas-oxid nanorészecskékkel hozható összefüggésbe.

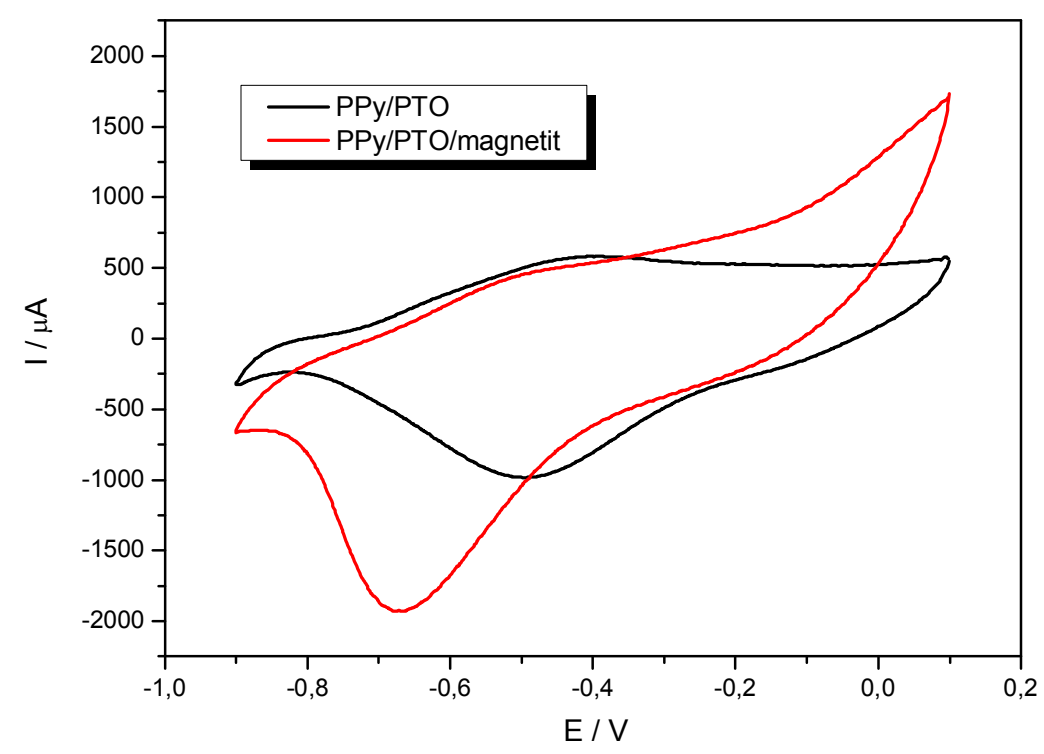

4.34. ábra A PPy/PTO és a PPy/PTO/magnetit elektródok ciklikus voltammogramja nitrogénnel telített foszfát-pufferben $(\mathrm{pH}=7) 50 \mathrm{mV} / \mathrm{s}$ ciklizálási sebesség mellett 
Eredmények és értékelésük

\subsubsection{PPy/PTO/magnetit és PPy/PTO rétegek katalitikus aktivitásának vizsgálata}

A már korábban említett vizsgálatok utaltak arra, hogy a $\mathrm{Fe}_{3} \mathrm{O}_{4}$ a hidrogén-peroxid bomlásának katalízise útján segíti elő az oxigén redukcióját. Ennek a hatásnak a részletesebb megismerésének az érdekében további vizsgálatokat folytattunk.

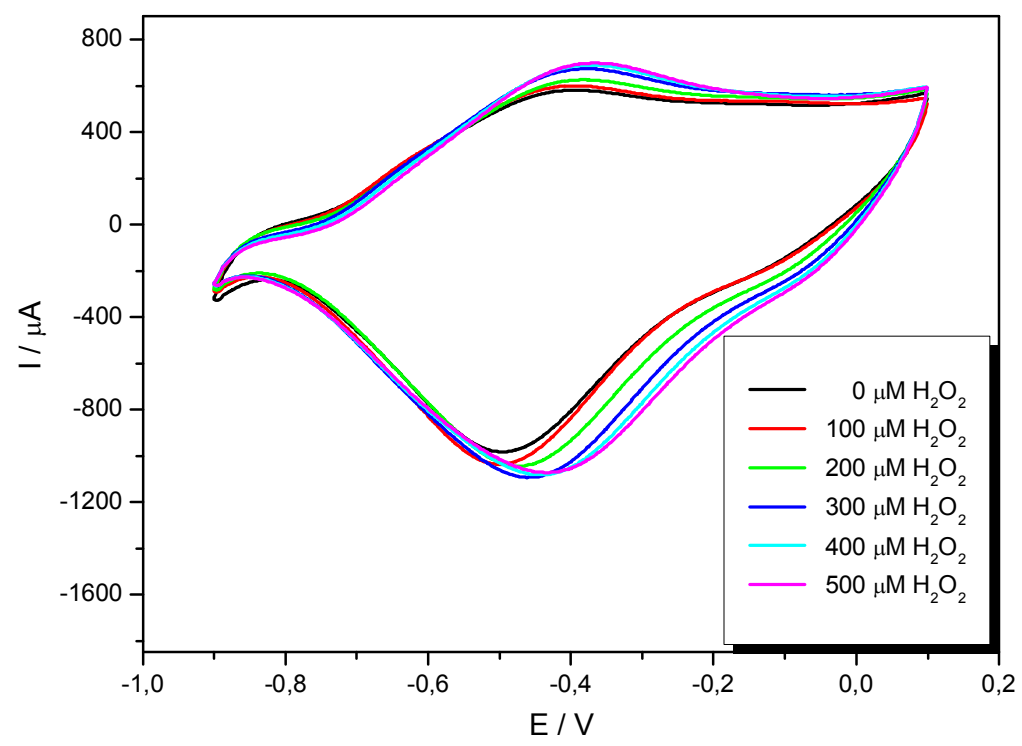

4.35. ábra A PPy/PTO elektród ciklikus voltammogramjai telített foszfát-pufferben $(\mathrm{pH}=7)$ $50 \mathrm{mV} / \mathrm{s}$ ciklizálási sebesség és különböző hidrogén-peroxid koncentrációk mellett $\mathrm{N}_{2}$ atmoszférában

A PPy/PTO vékonyréteg elektródon felvett (4.35. ábra) ciklikus voltammogramok sorozata szemlélteti a növekvő hidrogén-peroxid mennyiségének hatását hat különböző koncentráció mellett. Láthatjuk, hogy mind a katódos és az anódos félciklus alatt fokozatosan fejlődnek ki a többletáramok az oldat hidrogén-peroxid tartalmának növelésével. Az anódos végponttól indulva kezdetben az összes görbe együtt fut, de a 0,05 V potenciál értéknél negatívabb potenciálon a katódos áramok elkezdenek növekedni, és ez az áramnövekedés egészen a $-0,5 \mathrm{~V}$ potenciálértékig tart. Az anódos szakaszon hasonló tendencia figyelhető meg -0,5 - 0,0 V között. A PPy/PTO/magnetit elektród esetében (4.36. ábra) a következő megfigyeléseket tehetjük: a katódos szakaszon $0,05--0,7 \mathrm{~V}$ között, míg az anódos tartományban -0,7 - 0,0 V között nőnek a mért áram értékek a hidrogén-peroxid koncentrációjának növelésével. Szemmel látható, hogy nem csak a relatív növekedés, hanem az abszolút áramsürüségek is sokkal nagyobbak a hibridelektród esetében. 


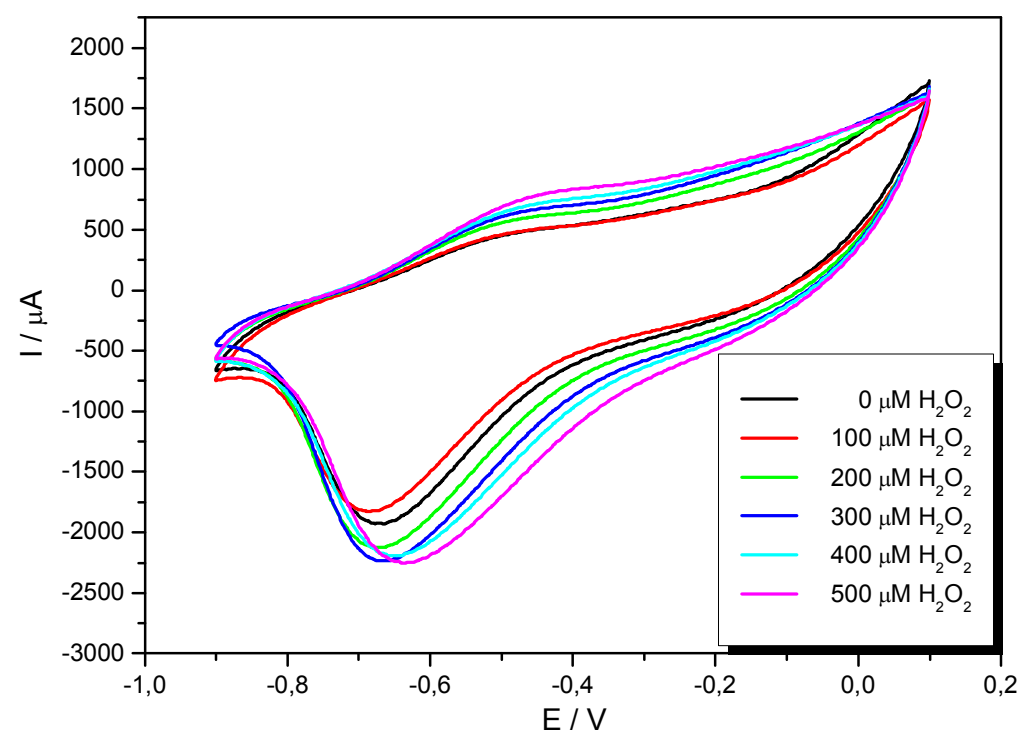

4.36. ábra A PPy/PTO/magnetit elektród ciklikus voltammogramjai foszfát-pufferben ( $\mathrm{pH}=7$ ) $50 \mathrm{mV} / \mathrm{s}$ ciklizálási sebesség és különböző hidrogén-peroxid koncentrációk mellett $\mathrm{N}_{2}$ atmoszférában

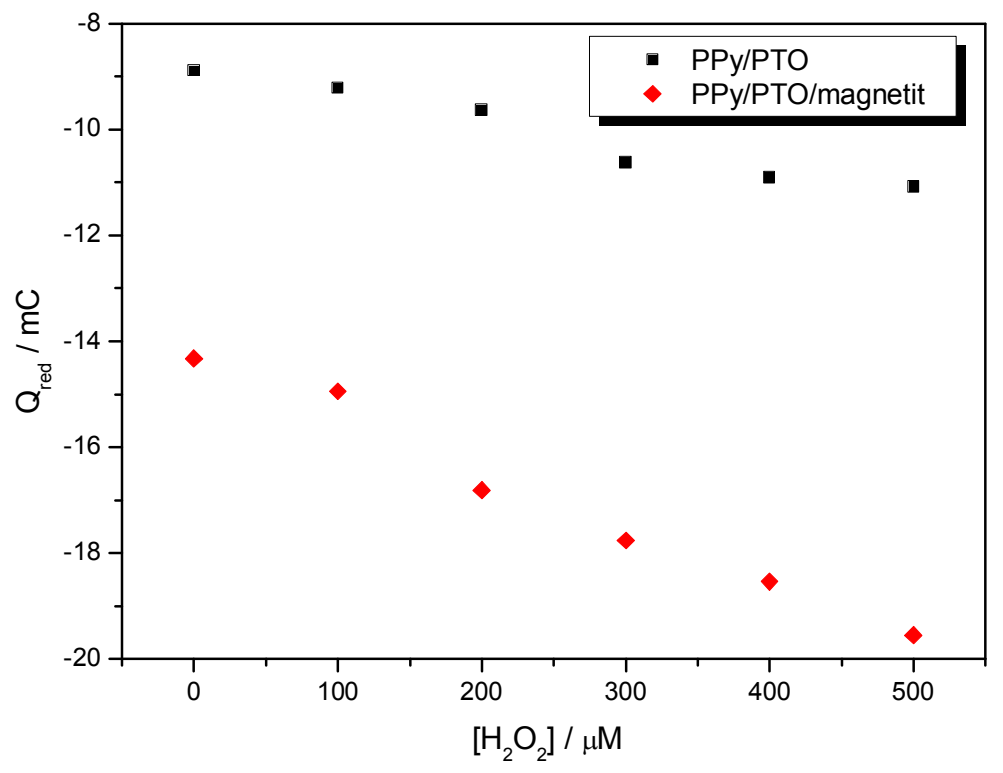

4.37. ábra A PPy/PTO és a PPy/PTO/magnetit elektródok voltammetriás ciklusainak redukciós töltései változó hidrogén-peroxid koncentrációknál $\mathrm{N}_{2}$ atmoszférában

Közvetlen információkat kaphatunk a fent említett hatásokról, ha átalakítjuk a 4.35. és a 4.36. ábrák hordozta információt. Annak érdekében, hogy szemléltetni tudjuk a katódos 
áramok és a hidrogén-peroxid tartalom kapcsolatát, illetve mennyiségileg kifejezzük az előbbi tapasztalatainkat, összehasonlítottuk a voltammetriás ciklusok alatt áthaladt katódos és össztöltéseket. Ha közelebbröl megvizsgáljuk a 4.37. és 4.38. ábrákon bemutatott eredményeket, két fontos különbség mutatkozik: a hibridelektród esetében jelentősen nagyobb töltéseket kaptunk, valamint sokkal nagyobb a töltés változása a hidrogén-peroxid koncentrációjának növelésével, azaz az elektród érzékenyebb a hidrogén-peroxid jelenlétére. Ez az aktivitás nem meglepő, mivel a magnetit jól ismert katalizátora a hidrogén-peroxid bomlásának [92], ám legjobb tudomásunk szerint a hidrogén-peroxid detektálása még nem valósult meg korábban vezető polimer/magnetit hibrid elektródon.

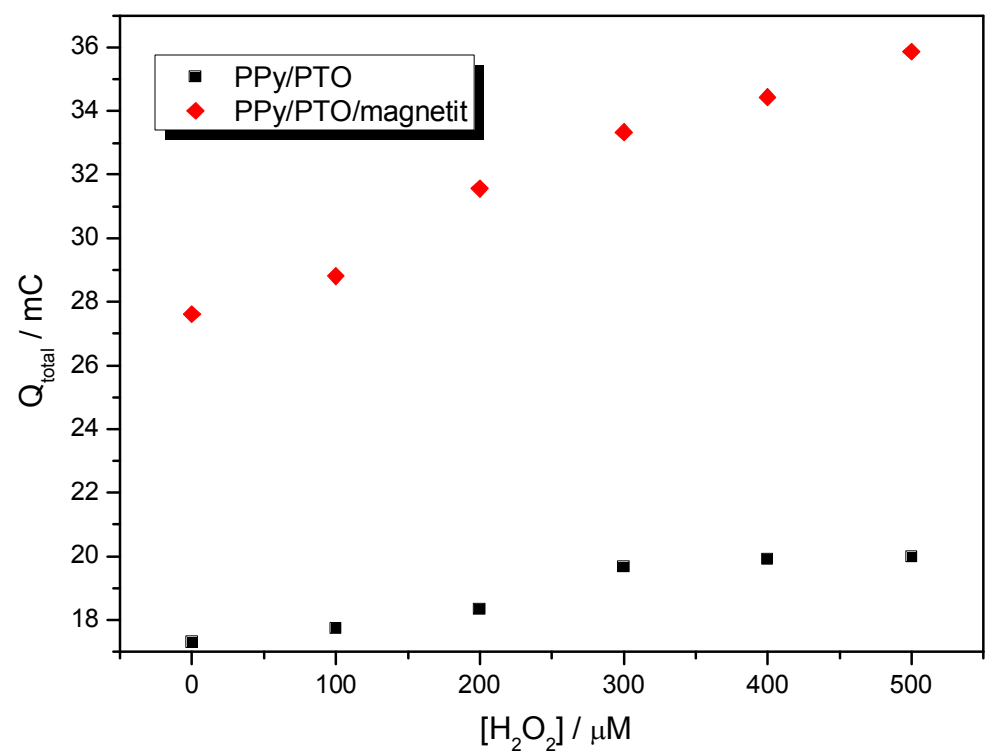

4.38. ábra A PPy/PTO és a PPy/PTO/magnetit elektródok voltammetriás ciklusainak össztöltései változó hidrogén-peroxid koncentrációknál $\mathrm{N}_{2}$ atmoszférában

A korábbi tapasztalataink alapján is felmerült már annak lehetősége, hogy a PPy/PTO/magnetit hibrid elektród szenzorként is hasznosítható lehet, ám nem szabad figyelmen kívül hagyni az oxigén redukciójában megismert szerepét, hiszen a két redukciós folyamat potenciáltartománya átfedésben van. Annak érdekében, hogy további részleteket szerezzünk a hidrogén-peroxid redukciójához köthető katódos áramok koncentráció függéséröl, kronoamperometriás méréseket végeztünk el $0-400 \mu \mathrm{M}$ koncentráció tartományba eső hidrogén-peroxidot tartalmazó oldatokban oldott oxigén kizárása és jelenléte mellett $-0,3 \mathrm{~V}$ potenciálon, mely értéket a relatív érzékenység alapján választottuk ki az 
alábbiak szerint. A 4.39. ábrán összehasonlítjuk az oxigén és a hidrogén-peroxid redukciójának amperometriás áramait két különböző potenciálon. Ezek az értékek -0,2 V potenciálnál negatívabb tartományban már jól mérhetővé válnak, ugyanakkor az is tisztán látható, hogy a negatívabb potenciál felé haladva a szelektivitás drasztikusan csökken. A -0,3 V értéket azért tartottuk optimálisnak, mivel a kevésbé negatív potenciálon a hidrogénperoxid redukciójával kapcsolatos katódos áramok túl kicsik.

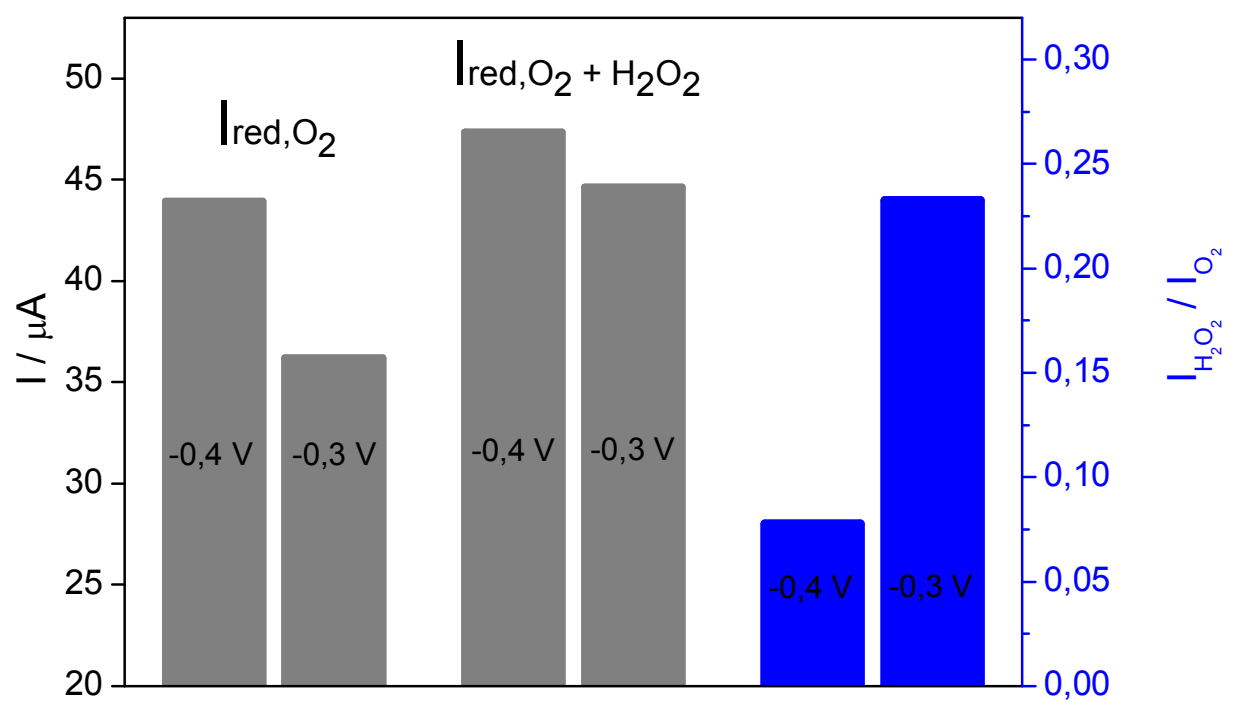

4.39. ábra Az oxigén és a hidrogén-peroxid redukciója során mért stacionárius áramok és azok arányának összehasonlítása két potenciál értéken $(E=-0,3$ V és $E=-0,4 V)$

Itt is azt az elvet követtük, hogy a magnetitet tartalmazó hibrid elektród és a „tiszta” polimer elektród eredményeit hasonlítjuk össze. A következő (4.40.) ábrán a PPy/PTO elektród kronoamperometriás görbéi láthatók hat különböző hidrogén-peroxid tartalomnál az oxigén kizárásával. Láthatjuk, hogy a görbék alakja hasonló, és megfigyelhető a stacionárius áramok fokozatos növekedése a hidrogén-peroxid mennyiségének növelésével. 


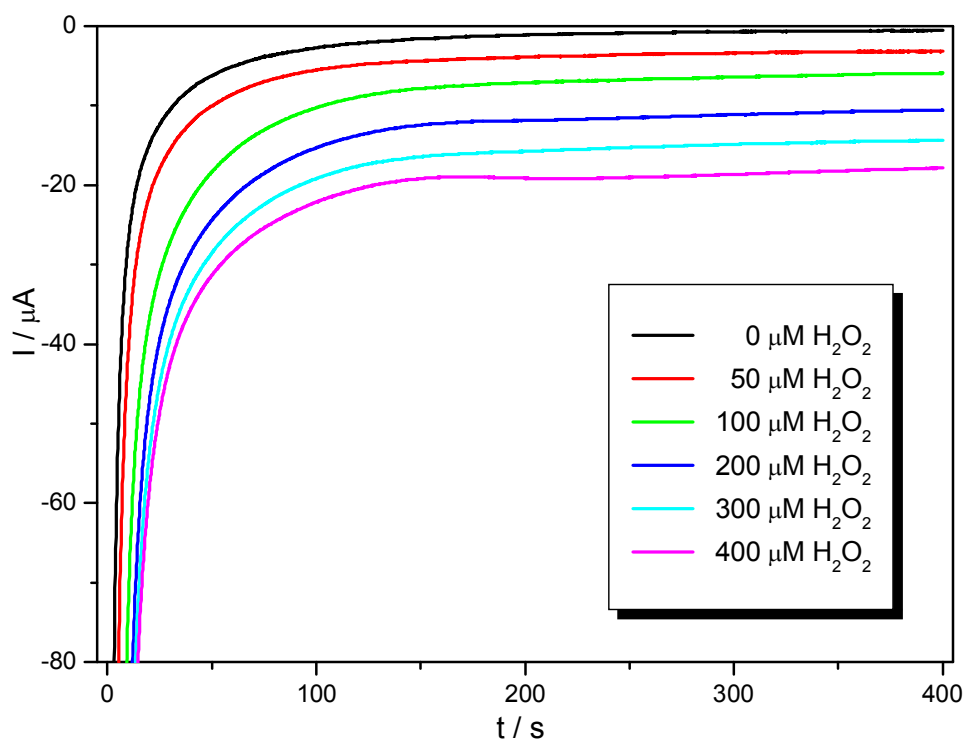

4.40. ábra A PPy/PTO elektród kronoamperometriás görbéi foszfát-pufferben $-0,3 \mathrm{~V}$ potenciálon felvéve különböző hidrogén-peroxid koncentrációk mellett $\mathrm{N}_{2}$ atmoszférában

Ezt követően az előbbi kísérleteket végrehajtottuk a mágneses nanorészecskét tartalmazó kompozit elektród esetében is. A kapott eredmények hasonlók (4.41. ábra), de a stacionárius áramok nagyobbak a hidrogén-peroxid adott koncentrációja mellett.

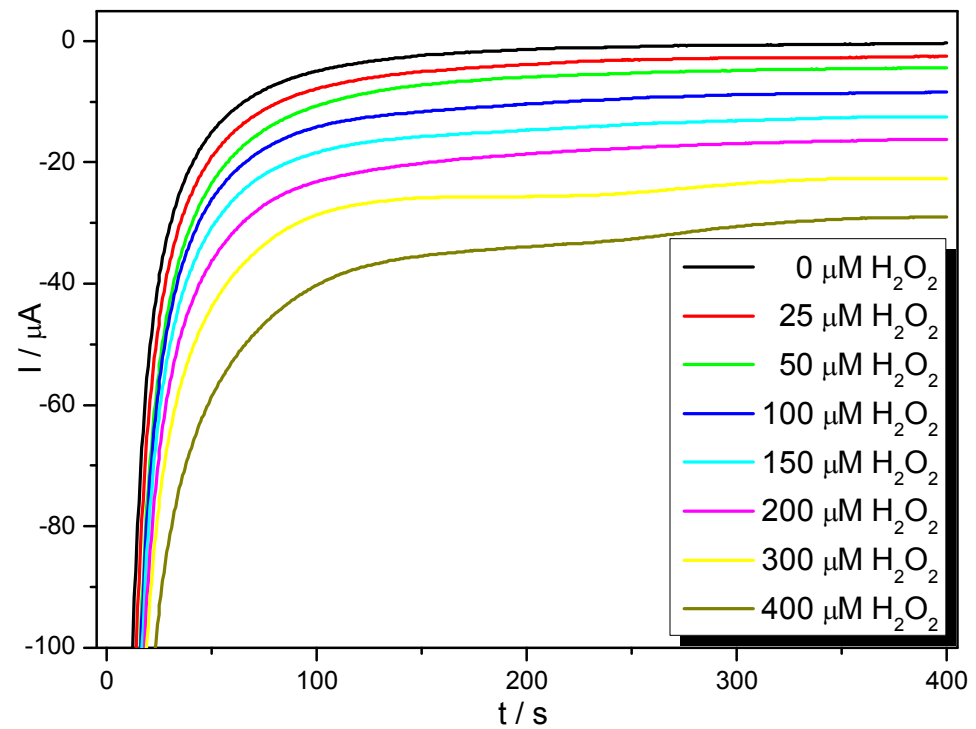

4.41. ábra A PPy/PTO/magnetit elektród kronoamperometriás görbéi foszfát-pufferben $-0,3 \mathrm{~V}$ potenciálon felvéve különböző hidrogén-peroxid koncentrációk mellett $\mathrm{N}_{2}$ atmoszférában 
A kapott eredmények szemléltetésére ábrázoltuk a stacionárius áramokat a hidrogénperoxid mennyiségének függvényében (4.42. ábra) szembeötlő az igen jó illesztéssel kapott lineáris kapcsolat.

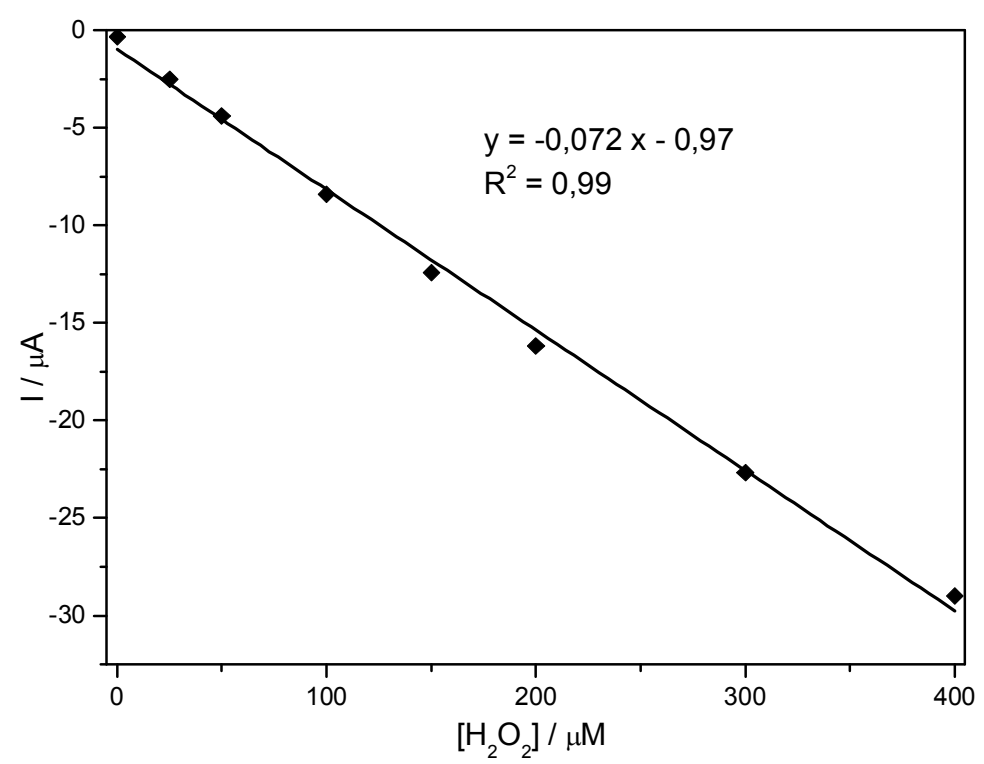

4.42. ábra A PPy/PTO/magnetit elektród kalibrációs görbéje, a kronoamperometriás mérésekből kapott stacionárius áramok a hidrogén-peroxid koncentrációk függvényében

A kompozit elektród laboratóriumi körülmények között tehát jól müködik, de érzékelöként történő jövőbeni hasznosítása esetén nagyon fontos, hogy képes legyen detektálni a hidrogén-peroxidot zavaró vegyületek jelenlétében is anélkül, hogy szükség legyen az újrakalibrálására minden egyes oldatban. A természetes és az ásványvizek tartalmazhatnak olyan anionokat mint nitrát, szulfát és klorid (némelyikük redukálható), ezért megvizsgáltuk az elektródunk és a módszerünk teljesítményét ezen anionok jelenlétében. Nátrium-klorid, nátrium-nitrát és nátrium-szulfát $0,1 \mathrm{M}$ koncentrációjú oldatait - amely több nagyságrenddel nagyobb, mint a természetes vizekben - készítettük el foszfát-pufferben, és kronoamperometriás méréseket végeztünk el $200 \mu \mathrm{M}$ hidrogén-peroxid tartalom mellett -0,3 V potenciálon. A 4.43. ábrán az azonos körülmények között mért stacionárius katódos áramok láthatók, melyek a kísérleti hibán belül megegyeznek. Így elmondható, hogy ezen anionok egyike sem zavarja a hidrogén-peroxid ezzel a módszerrel történő elektrokémiai meghatározását. 


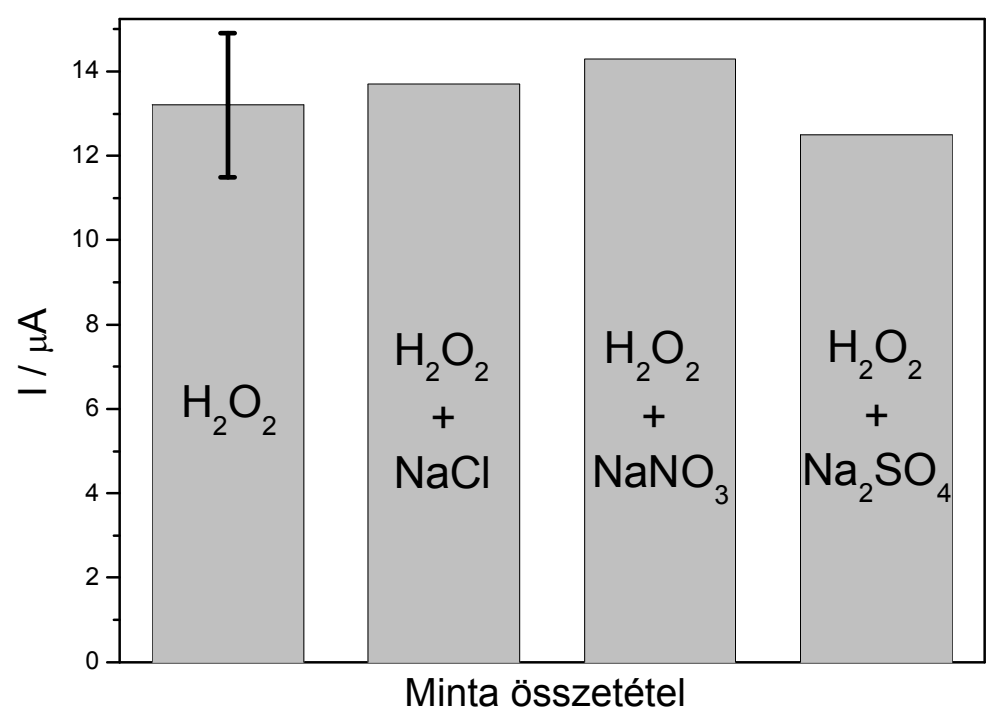

4.43. ábra A $200 \mu \mathrm{M}$ hidrogén-peroxidot tartalmazó foszfát-pufferben mért stacionárius katódos áramok különböző anionok jelenlétében

Elvégeztük a kronoamperometriás méréseket az 1,88 mg/l és 4,25 mg/l oldott oxigént tartalmazó oldatokban is növekvő hidrogén-peroxid koncentrációk mellett. A kapott eredmé-

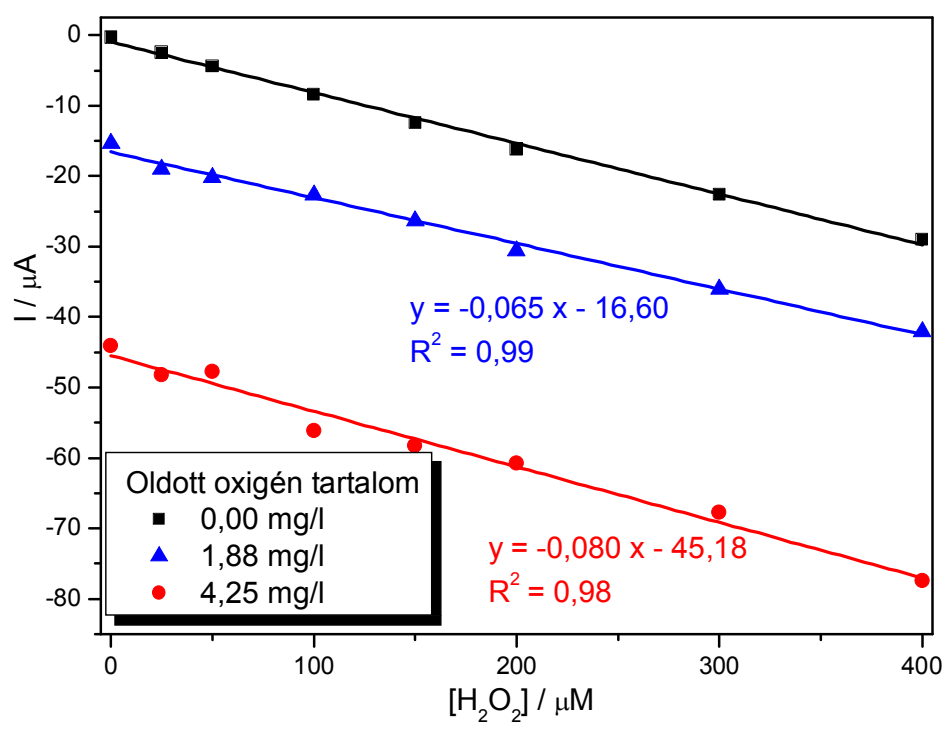

4.44. ábra A PPy/PTO/magnetit elektród kalibrációs görbéi, a kronoamperometriás mérésekből kapott stacionárius áramok a hidrogén-peroxid koncentrációk függvényében különböző oldott oxigén koncentrációk mellett 
nyek alapján elmondható (4.44. ábra), hogy a beállt, stacionárius állapotot közelítő áramértékek fokozatosan növekednek a hidrogén-peroxid koncentrációjának növelésével. Az ábrán a kapott stacionárius áramokat és összehasonlításként a nitrogén atmoszférában kapott kalibrációs egyenest is ábrázoltuk a hidrogén-peroxid mennyiségének függvényében. Az adatok egy kis szórás ellenére is egyértelműen bizonyítják a kapcsolatot a katódos áramok és a hidrogén-peroxid koncentrációja között, mind a két $(1,88 \mathrm{mg} / 1$ és 4,25 mg/l) oldott oxigén koncentráció mellett. Látható, hogy a kalibrációs görbék meredeksége közel azonos mind az oxigén kizárása, mind pedig jelenléte mellett. A három különböző oxigénkoncentráció tehát a kalibrációs görbének csupán a tengelymetszetét befolyásolja. Ennek alapján az elektród oxigénredukcióban történő kalibrációját követően - alkalmas a peroxid koncentráció meghatározására oxigén jelenlétében is. 


\subsection{4. $\mathrm{PPy} / \mathrm{PTO} / \mathrm{magnetit}$ réteg foto-elektrokatalitikus tulajdonságának vizsgálata}

A vasvegyületeknek az eddigiekben is feltárt fotokatalitikus hatása alapján következő lépésként megvizsgáltuk, mit tapasztalunk az előbbiekben említett kísérletsorozat megismétlésével annyi változtatás mellett, hogy a mérés során 200 s-től megvilágítottuk az elektródunkat (4.45. ábra). Jól látható, hogy a fény hatására rendre nőnek a redukciós áramok minden hidrogén-peroxid koncentráció esetében, és kvázi-stacionárius áramértékek érhetők el.

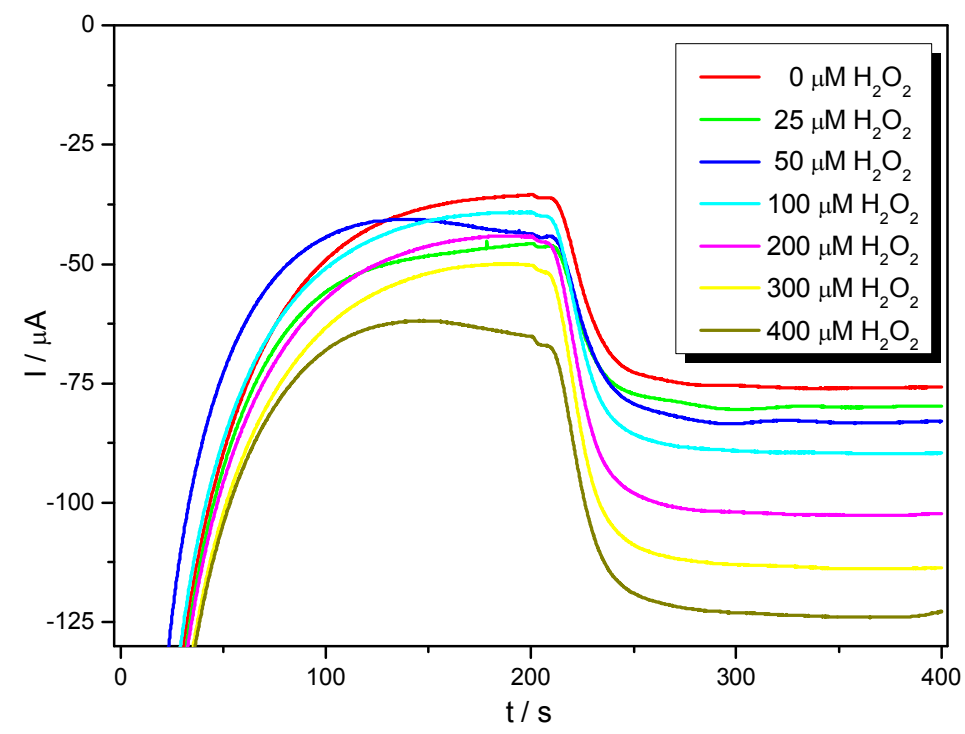

4.45. ábra A PPy/PTO/magnetit elektród kronoamperometriás görbéi $4,35 \mathrm{mg} / 1$ oldott oxigén koncentrációjú foszfát-pufferben $-0,3 \mathrm{~V}$ potenciálon felvéve különböző hidrogén-peroxid koncentrációk mellett 200 s-től megvilágítva

A 4.46. ábrán a megvilágítás hatására kapott stacionárius áramokat ábrázoltuk a hidrogén-peroxid mennyiségének függvényében. A lineáris kapcsolatot ebben az esetben is megkaptuk. Ha összehasonlítjuk a 4.44. és 4.46.ábra illesztett paramétereit, akkor megfigyelhetjük, hogy a megvilágítás esetén kapott meredekség közel másfélszeresére növekszik a megvilágítás nélkül kapott értékekhez képest, ami a PPy/PTO/magnetit elektródnak a hidrogén-peroxid redukciójára gyakorolt fotokatalitikus hatását bizonyítja. 


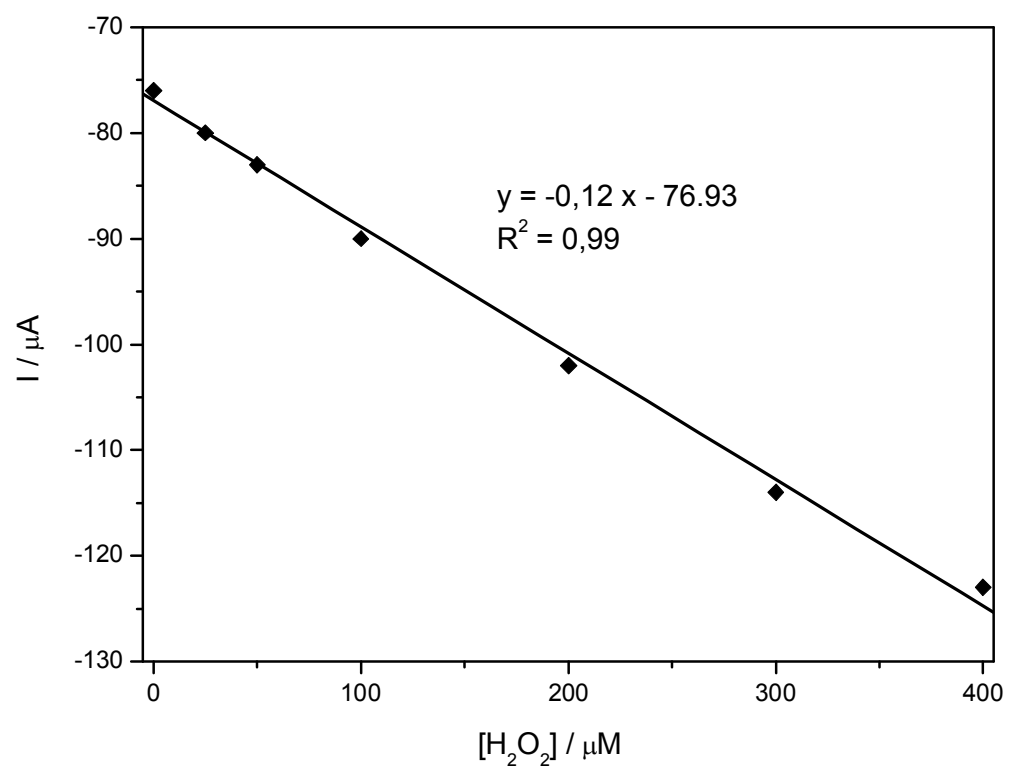

4.46 ábra A PPy/PTO/magnetit elektród kalibrációs görbéje, megvilágítás hatására a kronoamperometriás mérésekből kapott stacionárius áramok a hidrogén-peroxid koncentrációk függvényében

A különböző oxigén és hidrogén-peroxid koncentrációknál elvégzett kronoamperometriás méréseinkböl összeállítottuk a 4.47. ábrát, ami jól szemlélteti, hogy egy

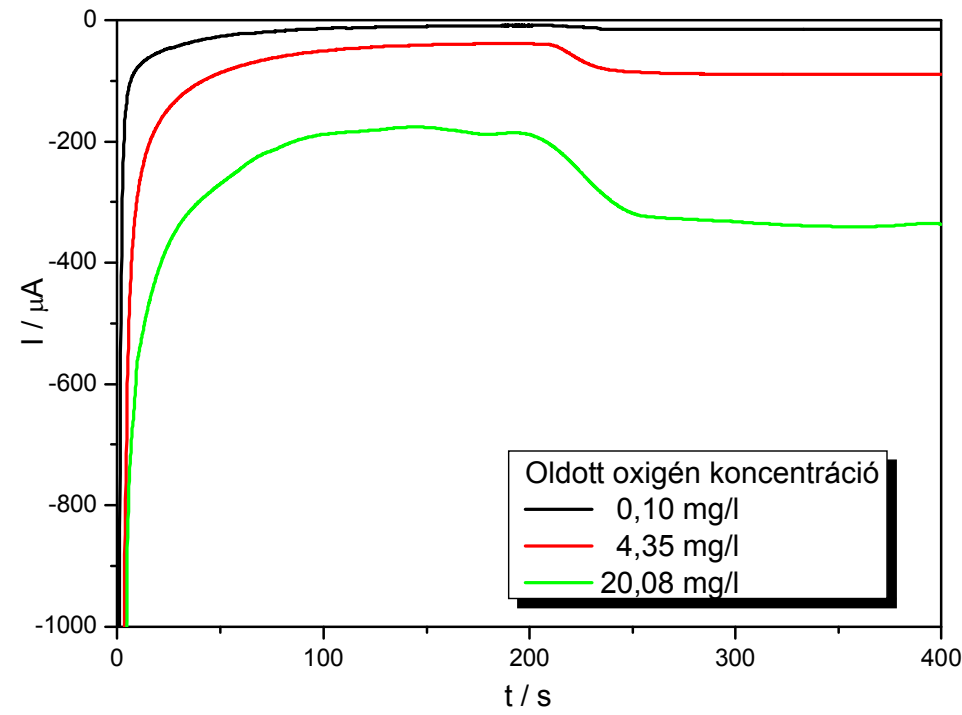

4.47. ábra A PPy/PTO/magnetit elektródon felvett kronoamperometriás görbék $100 \mu \mathrm{M}$ hidrogén-peroxidot tartalmazó foszfát pufferben 
adott hidrogén-peroxid tartalom mellett hogyan változnak a stacionárius áramok az oxigén tartalom változtatásával. Megfigyelhető, hogy az oldott oxigén koncentrációjának növelésével egyre nagyobb redukciós áramokat kapunk, ami megvilágítás hatására tovább növekszik.

A katódos áramok abszolút értékének növekedése alapján elmondhatjuk, hogy a megvilágítás hatására gyorsul mind a hidrogén-peroxid mind az oxigén redukciójának a sebessége. A levegőn telített oxigéntartalmú oldat esetén felvett kalibrációs görbe meredekségének növekedése fontos az érzékenység és a kimutatási határ szempontjából. 
Összefoglalás

\section{Összefoglalás}

A doktori munkám során vezető polimerek különböző vasvegyületekkel alkotott kompozitjait állítottam elő. Ennek során többféle utat próbáltam ki.

1. Sikerrel építettem be vas-oxalátot hidrogén-peroxidos utókezeléssel frissen készített polipirrolba és poli(3-oktil-tiofén)-be.

2. Az irodalomban elöször egyéb vezetősó nélkül, kizárólag vas-oxalátot tartalmazó monomeroldatból elektrokémiai úton állítottam elő polipirrolt, illetve poli(3,4-etilén-dioxitiofén)-t.

3. Magnetit nanorészecskék jelenlétében választottam le elektrokémiai polimerizációval polipirrol réteget egy korábban már a kutatócsoport által kidolgozott eljárás szerint, speciális vezetősó alkalmazásával.

Az elóállított hibrid anyagokat azon tulajdonságuk is összekapcsolja, hogy a szerves vezető polimerek közismert fotokatalitikus hatását a beépített vastartalmú vegyületek minden esetben jelentősen megnövelik. A szintézisek útján olyan elektródokat kaptunk, melyek alkalmazhatók foto-elektrokatalitikus folyamatokban, vagy alapul szolgálhatnak analitikai célú eszközök kifejlesztéséhez.

1.1. Polipirrol esetén a röntgendiffrakciós mérések során a vastartalmú komponens jelenlétét két azonosított reflexió megjelenésével bizonyítottam. A politiofén-származék esetében a röntgendiffrakciós eredmények a hordozó polimer réteges szerkezetét igazolták. A reflexiók intenzitásának csökkenése, valamint eltolódásai alapján arra következtettem, hogy az oktil-tiofén láncok rövidebb és hosszabb távú kölcsönhatásait egyaránt gyengítette a beépülő szervetlen komponens. Ennek alapján megállapítható, hogy jelenléte mind a gyökkationgyökkation kölcsönhatást, mind az oldalláncok kölcsönhatásaiból eredő „fésűs”, lamelláris szerkezetet befolyásolta.

2.1. Munkám második részében a kapott eredmények azt bizonyították, hogy sikerült vízben diszpergált vas(II)-oxalát jelenlétében minden egyéb vezetősó adagolása nélkül polipirrol filmet elóállítani. A rétegképződést elektrokémiai kvarckristály-mikromérleg (EQCM) technikával is tanulmányoztam. Ezen eredmények azt mutatták, hogy a felületen képződő oxidált állapotú polimer pozitív töltéseit nem kizárólag a legegyszerübben valószínúsíthető egymagvú komplex anionok, hanem jelentős mértékben a vegyes oxidációs állapotú komplex vas-oxalát ionok kompenzálják. E feltételezést sikerült alátámasztani 
Összefoglalás

Mössbauer-spektroszkópiás vizsgálatokkal, melyeknek vas(II) és vas(III) arányra vonatkozó eredményei alapján arra következtettem, hogy a film $\left[\mathrm{Fe}(\mathrm{II}) \mathrm{Fe}(\mathrm{III})(\mathrm{ox})_{3}\right]^{-}$és $\left[\mathrm{Fe}(\mathrm{III})(\mathrm{ox})_{3}\right]^{3-}$ anionokat tartalmaz. A vas(II)/vas(III) arányból számítással nyert adatok jó közelítéssel mutattak egyezést a kvarckristály mikromérleggel mért kísérleti eredményekkel.

2.2. Eredményeimmel bemutattam, hogy az EDOT elektrokémiai polimerizációja is megvalósítható vas(II)-oxalát jelenlétében oly módon, hogy más elektrolitot nem tartalmaz az oldat. A kapott réteg stabil, redoxi aktivitása is hosszantartó, bomlás vagy túloxidáció jelei nem mutatkoznak rajta. Ha az oldat oldott oxigént tartalmaz, akkor a film redoxi átalakítása aszimmetrikussá válik, és nagy katódos töltéstöbbletet mutat. Bizonyítottam, hogy a többlet katódos töltés az oldott oxigén redukciójával van kapcsolatban.

2.3. A PEDOT/vas-oxalát réteg - mint $\mathrm{p}$ típusú félvezető - foto-elektrokatalitikus hatást mutat, ami a film semleges formájának a gerjesztéséhez kapcsolódik. A negatív fotoáram függ az oxigén mennyiségétől, ez a függés lineáris korrelációt ad a katódos fotoáram és az oldott oxigén koncentrációja között. Így a PEDOT/vas-oxalát kompozit elektród mint foto-elektrokémiai szenzor felhasználható vizes oldatok oxigénkoncentrációjának mérésére. Elektródunk detektálási határa 1 ppm alatti tartományba esik, és a dinamikus tartomány 20 ppm koncentrációig terjed.

3.1. A speciális vezetősó (PTO) jelenlétében készített PPy/magnetit hibrid elektród elektrokémiai viselkedését a magnetit nélkül azonos módon elóállított polimerével összehasonlítva bizonyítottam a magnetit beépülését, melyre a jelentősen megnövekedett elektroaktivitás utalt. Az eredmények alapján arra következtettem, hogy a PPy/PTO/magnetit hibrid elektród különösen a kis koncentrációk tartományában alkalmas vizes oldatok hidrogénperoxid tartalmának mennyiségi meghatározására. Ezt a $0-400 \mu \mathrm{M}$ koncentrációtartományban végzett tranziens és a stacionárius amperometriás mérésekkel támasztottam alá. Az elektród megnövekedett aktivitását jól követhetjük, ha összehasonlítjuk a tiszta polimer viselkedésével. Ez fényt derített arra, hogy a PPy/PTO/magnetit hibrid elektródnak a hidrogén-peroxid elektrokémiai redukciója során tapasztalt jelentős áramnövelő hatása a közismerten katalizátor szerepủ magnetit nanorészecskékhez köthető, azaz a hatás beépített formában is megfigyelhetö.

3.2. A PPy/PTO/magnetit elektródon oldott oxigén és hidrogén-peroxid együttes jelenlétében amperometriás technikával mért áramok ezek egyidejü redukciójából származnak. 
Igazoltam azonban, hogy az oxigén zavaró hatása kiküszöbölhető a potenciál értékének célirányos megválasztásával. Bizonyítottam, hogy $-0,3 \mathrm{~V}$ potenciálon a hidrogén-peroxid redukciója során mért áramok felhasználásával nyert kalibrációs görbék meredeksége azonos mind az oxigén kizárása, mind pedig jelenléte mellett. Kimutattam, hogy a három jelentősen különböző oxigénkoncentráció (oxigén kizárása mellett, illetve levegöből, valamint tiszta oxigénnel telített oldatban) - a kalibrációs görbék párhuzamos eltolódása folytán - ezeknek csupán tengelymetszetét befolyásolja. Ennek jelentőségét abban látom, hogy az elektród oxigénredukcióban történő kalibrációját követően alkalmas lehet a peroxid-koncentráció meghatározására oxigén jelenlétében is, mely képesség példa nélküli a jelenlegi szakirodalomban.

3.3. Megvizsgáltam, hogy a megvilágítás milyen hatással van a PPy/PTO/magnetit elektród imént bemutatott elektrokatalitikus aktivitására. Egyensúlyi oxigénkoncentráció mellett $-0,3 \mathrm{~V}$ potenciálon a kapott stacionárius fotoáramok a hidrogén-peroxid mennyiségének függvényében lineáris függést mutattak. Összehasonlítva a megvilágítás nélkül és a megvilágítás hatására kapott kalibrációs egyenesek illesztett paramétereit megállapítottam, hogy a megvilágítás esetén kapott meredekség mintegy másfélszerese a megvilágítás nélkül kapott értékeknek, így az elektródon alapuló foto-elektrokémiai hidrogénperoxid érzékelő későbbi kifejlesztésénél ezen érzékenységnövekedés is hasznosítható. 


\section{Summary}

In my doctoral work conducting polymer composites, formed with various iron compounds, were synthesized. During the experiences, I tried different ways.

1. Iron oxalate was built successfully in freshly prepared poly(3-octylthiophene) and polypyrrole through a post-treatment by hydrogen peroxide.

2. For the first time in the literature polypyrrole and poly(3,4-ethylenedioxythiophene) were prepared electrochemically from monomer solutions containing exclusively iron oxalate, without other conducting salt.

3. Using a special conducting salt polypyrrole layer was deposited in the presence of magnetite nanoparticles by an electrochemical polymerization procedure, elaborated recently by our research group.

The properties of the prepared hybrid materials are also linked by the fact that in all cases the well known photocatalytic effect of organic conductive polymers increased significantly in the presence of the built-in iron-containing compounds. Through the synthesis we obtained electrodes that can be used in photo-electrocatalytic processes, or can serve as a basis for the future development of appliance with analytical purposes.

1.1. In the case of polypyrrole, the X-ray diffraction measurements proved the presence of iron-containing component by the appearance of two identified reflections. The X-ray diffraction results obtained with the polythiophene derivatives confirmed the layered structure of the polymer substrate. From the decrease in the intensity of the reflections and their shifts, the weakening of short- and long-distance interactions between octylthiophene chains caused by the built-in inorganic component could be concluded, hence its presence influenced both the radical cation - radical cation interactions and the interactions between side-chains, resulting a comb-like, lamellar structure.

2.1. The results obtained in the second part of the work showed that polypyrrole film was successfully produced in the presence of iron (II) oxalate dispersed in water, without the addition of any other conducting salt. The layer formation was studied also by the electrochemical quartz crystal microbalance (EQCM) technique. These results indicated that the positive charges of the polymer formed on the surface in the oxidized state are compensated not only by the most probable oxalate containing complex anions, but in a significant extent also by oxalate complex ions, containing irons in mixed oxidation state. This 
hypothesis was supported by Mössbauer spectroscopy studies: from the ratio of iron(II) and iron(III) it was concluded that the film contains both $\left[\mathrm{Fe}(\mathrm{II}) \mathrm{Fe}(\mathrm{III})(\mathrm{ox})_{3}\right]^{-}$and $\left[\mathrm{Fe}(\mathrm{III})(\mathrm{ox})_{3}\right]^{3-}$ anions. The data calculated from iron(II)/iron(III) ratio showed a good agreement with the experimental results obtained from the quartz crystal microbalance measurements.

2.2. The results showed that the electrochemical polymerization of EDOT is feasible in the presence of iron (II) oxalate in such a way that the solution does not contain any other electrolyte. The layer was stable, performed a sustained redox activity, did not show signs of decay or overoxidation. If the solution contained dissolved oxygen, the redox transformation of the film became asymmetric and exhibited a high cathodic charge surplus. The excess of this cathodic charge originated from the reduction of dissolved oxygen.

2.3. The PEDOT/iron oxalate layer - as a p-type semiconductor - exhibited photoelectrocatalytic effect which was connected to excitation of the neutral form of the film. The negative photocurrent depended on the amount of oxygen, this dependence gave a linear correlation between the cathodic photocurrent and the concentration of the dissolved oxygen. Thus, the PEDOT/iron oxalate composite electrode as a photo-electrochemical sensor can be used for measuring the concentration of oxygen in aqueous solutions. The detection limit of our electrode is below $1 \mathrm{ppm}$, and the dynamic range extends up to $20 \mathrm{ppm}$ concentration.

3.1. The formation of the PPy/magnetite hybrid electrode prepared in the presence of a special conducting salt (PTO) could be proved by comparing its significantly increased activity with the electrochemical behaviour of the polymer electrode, produced without magnetite under otherwise identical conditions. Based on these results it was concluded that the PPy/PTO/magnetite hybrid electrode is particularly suitable for measuring the hydrogen peroxide content of aqueous solutions especially in the range of low concentrations. This conclusion was supported by transient and steady-state amperometric measurements in the 0 $400 \mu \mathrm{M}$ hydrogen peroxide concentration range. The increased activity of the electrode could be easily traced when comparing it with the behaviour of the pure polymer. This comparison revealed that the significant current increasing effect of PPy/PTO/magnetite hybrid electrode registered in the electrochemical reduction of hydrogen peroxide can be associated with the well-known catalytic behaviour of magnetite nanoparticles, preserved also in the in-built form.

3.2. Currents detected by the amperometric technique at the PPy/PTO/magnetite electrode in the presence of both the dissolved oxygen and hydrogen peroxide originated from 
their concurrent reductions. It has been proved, however, that the disturbing effect of oxygen can be eliminated by applying a properly chosen potential value. It has been demonstrated that the slopes of the calibration curves, obtained either with the exclusion or in the presence of oxygen from the currents of hydrogen peroxide reduction at a potential of $-0.3 \mathrm{~V}$, are identical. It has been shown that the three significantly different oxygen concentrations (de-oxygenated, saturated from air and from pure oxygen) affect only the intercept of the calibration curves owing to their parallel shift. This fact is important if we take into consideration that the electrode can be used to determine the concentration of peroxide in the presence of oxygen after its calibration in the oxygen reduction. To the best of my knowledge, it is unique in the literature.

3.3. The effect of the illumination on the above described electroactivity of the PPy/PTO/magnetite electrode has been examined. The stationary photocurrents obtained at potential value of $-0.3 \mathrm{~V}$ at increasing amounts of hydrogen peroxide and at an equilibrium concentration of oxygen followed a linear dependence. By comparing the fitting parameters of the calibration curves obtained under illumination and in the dark, a one and a half times larger slope was obtained in the former case. This increase in the sensitivity of a photoelectrochemical hydrogen peroxide sensor, based on the future development of this electrode, can be exploited. 


\section{Irodalomjegyzék}

[1] Inzelt G., Kalandozások a kémia múltjában és jelenében Vince Kiadó (2003) 34.

[2] R. McNeill, R. Siudak, J. H. Wardlaw, D. E. Weiss, Australian Journal of Chemistry $16(1963) 1056$.

[3] H. Shirakawa, E. J. Louis, A. G. MacDiarmid C. K. Chiang, A. J. Heeger, Journal of the Chemical Society, Chemical Communications (1977) 578.

[4] A. F. Diaz, K. K. Kanazawa, G. P.Gardini, Journal of the Chemical Society, Chemical Communications (1979) 635.

[5] H. Naarmann, N. Theophilou, Synthetic Metals 22 (1987) 1.

[6] G. Schiavon, G. Zotti, G. Bontempelli, Journal of Electroanalytical Chemistry 161 (1984) 323.

[7] E. G. Castro, A. J. G. Zarbin, A. Galembeck, Journal of Non-Crystalline Solids 351 (2005) 3704.

[8] M. Hasik, W. Turek, A. Nyczyk, E. Stochmal, A. Bernasik, A. Sniechota, A. Sołtysek, Catalysis Letters 127 (2009) 304.

[9] N. Cioffi, L. Torsi, L. Sabbatini, P. G. Zambonin, T. Bleve-Zacheo, Journal of Electroanalytical Chemistry 488 (2000) 42.

[10] W. Chen, C. M. Li, P. Chen, C. Q. Sun, Electrochimica Acta 52 (2007) 2845.

[11] E. Pintér, R. Patakfalvi, T. Fülei, Z. Gingl, I. Dékány, C. Visy, Journal of Physical Chemistry B 109 (2005) 17474.

[12] N. Hebestreit, J. Hofmann, U. Rammelt, W. Plieth, Electrochimica Acta 48 (2003) 1779 .

[13] Q. T. Vu, M. Pavlik, N. Hebestreit, J. Pfleger, U. Rammelt, W. Plieth, Electrochimica Acta 51 (2005) 1117.

[14] Y. T. Ravikiran, M. T. Lagare, M. Sairam, N. N. Mallikarjuna, B. Sreedhar, S. Manohar, A. G. MacDiarmid, T. M. Aminabhavi, Synthetic Metals 156 (2006) 1139.

[15] M. V. Murugendrappa, A. Parveen, M. V. N. A. Prasad, Materials Science and Engineering. A 459 (2007) 371.

[16] J. C. Aphesteguy, S. E. Jacobo, Physica B 354 (2004) 224.

[17] C. Janáky, C. Visy, Synthetic Metals 158 (2008) 1009. 
Irodalomjegyzék

[18] R. Mathur, D. R. Sharma, S. R. Vadera, N. Kumar, Acta Materialia 49 (2001) 181.

[19] S. Sathiyanarayanan, S. S. Azim, G. Venkatachari, Synthetic Metals 157 (2007) 751.

[20] M. G. Hosseini, M. Sabouri, T. Shahrabi, Progress in Organic Coatings 60 (2007) 178.

[21] L. Chen, C. Yuan, B. Gao, S. Chen, X. Zhang, Journal of Solid State Electrochemistry 13 (2009) 1925.

[22] N. P. Gaponik, D. V. Talapin, A. L. Rogach, A. Eychmuller, Journal of Materials Chemistry 10 (2000) 2163.

[23] Z. Han, J. Zhang, X. Yang, H. Zhu, W. Cao, Journal of Inorganic and Organometallic Polymers and Materials 20 (2010) 649.

[24] J. Azadmanjiri, P. Hojati-Talemi, G. P. Simon, K. Suzuki, C. Selomulya, Polymer Engineering and Science 51 (2011) 247.

[25] S. Mokrane, L. Makhloufi, H. Hammache, B. Saidani, Journal of Solid State Electrochemistry 5 (2001) 339.

[26] A. Malinauskas, Synthetic Metals 107 (1999) 75.

[27] A. Ramanavicius, A. Ramanaviciene, A. Malinauskas, Electrochimica Acta 51 (2006) 6025 .

[28] U. Lange, N. V. Roznyatovskaya, V. M. Mirsky, Analytica Chimica Acta 614 (2008) 1.

[29] K. Brazdziuviene, I. Jureviciute, A. Malinauskas, Electrochimica Acta 53 (2007) 785.

[30] L. Zhang, H. Peng, P. A. Kilmartin, C. Soeller, J. Travas-Sejdic, Macromolecules 41 (2008) 7671.

[31] D. Oukil, L. Makhloufi, B. Saidani, Sensors and Actuators B 123 (2007) 1083.

[32] S. S. Kumar, J. Mathiyarasu, K. L. N. Phani, V. Yegnaraman, Journal of Solid State Electrochemistry 10 (2005) 905.

[33] H.-S. Wang, D.-Q. Huang, R.-M. Liu, Journal of Electroanalytical Chemistry 570 (2004) 83.

[34] Y.-P. Hsiao, W.-Y. Su, J.-R. Cheng, S.-H. Cheng, Electrochimica Acta 56 (2011) 6887.

[35] C. Zanardi, F. Terzi, R. Seeber, Sensors and Actuators B 148 (2010) 277.

[36] L. Pigani, G. Foca, K. Ionescu, V. Martina, A. Ulrici, F. Terzi, M. Vignali, C. Zanardi, R. Seeber, Analytica Chimica Acta 614 (2008) 213.

[37] V. C. Ferreira, A. I. Melato, A. F. Silva, L. M. Abrantes, Electrochimica Acta 56 (2011) 3567. 
Irodalomjegyzék

[38] A. Stoyanova, V. Tsakova, Journal of Solid State Electrochemistry 14 (2010) 1947.

[39] H. Nguyen-Cong, V. D. Guadarrama, J. L. Gautier, P. Chartier, Electrochimica Acta 48 (2003) 2389.

[40] A. Lupu, P. Lisboa, A. Valsesia, P. Colpo, F. Rossi, Sensors and Actuators B 137 (2009) 56.

[41] A. Deronzier, J.-C. Moutet, Coordination Chemical Reviews 147 (1996) 339.

[42] A. Ernst, S. Zoladek, K. Wiaderek, J. Cox, A. Kolaryzurowska, K. Miecznikowski, P. Kulesza, Electrochimica Acta 53 (2008) 3924.

[43] K. Crowley, E. O’Malley, A. Morrin, M. R. Smyth and A. J. Killard, Analyst 133 (2008) 391.

[44] L. C. Clark, Transactions - American Society for Artificial Internal Organs 2 (1956) 41.

[45] A. S. Holmes-Smith, A. Hamill, M. Campbell and M. Uttamlal, Analyst 124 (1999) 1463.

[46] P. Gajendran, R. Saraswathi, Journal of Physical Chemistry C 111 (2007) 11320.

[47] T. Ruzgas, E. Csöregi, J. Emnéus, L. Gorton, G. Marko-Varga, Analytica Chimica Acta 330 (1996) 123.

[48] G. Delaragonzalez, H. Kahlert, F. Scholz, Electrochimica Acta 52 (2007) 1968.

[49] A. Salimi, M. Mahdioun, A. Noorbakhsh, A. Abdolmaleki, R. Ghavami, Electrochimica Acta 56 (2011) 3387.

[50] A. Damjanovic, B. E. Murphy, O. J. Srinivasan, S. Conway (Eds.), Electrochemistry in Transition, Plenum Press, New York, (1992) 107.

[51] R. R. Adzic, in: P. N. Lipkowski, J. Ross (Eds.), Electrocatalysis, Wiley-VCH, New York, (1998) 197.

[52] S. Gaspar, K. Habermüller, E. Csöregi, W. Schuhmann, Sensors and Actuators B 72 (2001) 63.

[53] B. D. Malhotra, A. Chaubey, S. P. Singh, Analytica Chimica Acta 578 (2006) 59.

[54] S. Cosnier, Biosensors and Bioelectronics 14 (1999) 443.

[55] Y.-T. Kong, M. Boopathi, Y.-B. Shim, Biosensors and Bioelectronics 19 (2003) 227.

[56] J. Li, R. Yuan, Y. Chai, T. Zhang, X. Che, Microchimica Acta 171 (2010) 125. 
Irodalomjegyzék

[57] H.-W. Siao, S.-M. Chen, K.-C. Lin, Journal of Solid State Electrochemistry 15 (2010) 1121.

[58] C. Debiemme-Chouvy, Biosensors and Bioelectronics 25 (2010) 2454.

[59] A. R. Gonçalves, M. E. Ghica, C. M. a Brett, Electrochimica Acta 56 (2011) 3685.

[60] E. R. Vago, E. J. Calvo, Journal of Electroanalytical Chemistry 388 (1995) 161.

[61] D. Fu, X. Zhang, P. G. Keech, D. W. Shoesmith, J. C. Wren, Electrochimica Acta 55 (2010) 3787.

[62] J. Chumming, L. Xiangqin, Journal of Solid State Electrochemistry 13 (2008) 1273.

[63] L. Zhang, Y. Zhai, N. Gao, D. Wen, S. Dong, Electrochemistry Communications 10 (2008) 1524.

[64] G. Zhao, J.-J. Xu, H.-Y. Chen, Electrochemistry Communications 8 (2006) 148.

[65] S. Qu, J. Wang, J. Kong, P. Yang, G. Chen, Talanta 71 (2007) 1096.

[66] P. A. Kilmartin, G. A. Wright, Electrochimica Acta 41 (1996) 1677.

[67] S. das Neves, C. N. P. da Fonseca, M.-A. De Paoli, Synthetic Metals 89 (1997) 167.

[68] F. L. C. Miquelino, M.-A. De Paoli, E. M. Geniès, Synthetic Metals 68 (1994) 91.

[69] P. A. Kilmartin, G. A. Wright, Electrochimica Acta 46 (2001) 2787.

[70] R. L. N. Chandrakanthi, M. A. Careem, Thin Solid Films 417 (2002) 51.

[71] M. Refczynska, J. Mieczkowski, M. Skompska, Electrochimica Acta 53 (2008) 2984.

[72] Z. Han, J. Zhang, X. Yang, H. Zhu, W. Cao, Solar Energy Materials and Solar Cells 94 (2010) 194.

[73] Janáky C. Doktori (Ph.D.) értekezés (2010)

[74] Z. L. Liu, Y. J. Liu, K. L. Yao, Z. H. Ding, J. Tao, X. Wang, Journal of Materials Synthesis and Processing. 10 (2002) 83.

[75] L. L. Miller, K. R. Mann, Accounts of Chemical Research 29 (1996) 417.

[76] E. Kriván, C. Visy, J. Kankare, Journal of Physical Chemistry B 107 (2003) 1302.

[77] M. A. De Paoli, S. Panero, P. Prosperi, B. Scrosati, Electrochimica Acta 35 (1990) 1145 .

[78] M. Skompska, A. Jackson, A.R. Hillman, Physical Chemistry Chemical Physics 2 (2000) 4748.

[79] G. Z. Sauerbrey, Zeitschrift für Physik 155 (1959) 206.

[80] G. Inzelt, V. Kertész, Electrochimica Acta 42 (1997) 229. 
[81] C. Visy, J. Lukkari, J. Kankare, Synthetic Metals 33 (1989) 289.

[82] E. Krivan, C. Visy, J. Kankare, Electrochimica Acta 50 (2005) 1247.

[83] G. Heywang, F. Jonas, Advanced Materials 4 (1992) 116.

[84] Q. B. Pei, G. Zuccarello, M. Ahlskog, O. Inganas, Polymer 35 (1994) 1347.

[85] H. J. Ahonen, J. Lukkari, J. Kankare, Macromolecules 33 (2000) 6787.

[86] H. Gustafsson, C. Kvarnström, A. Ivaska, Thin Solid Films 517 (2008) 474.

[87] A. J. Bard, L. R. Faulkner Electrochemical Methods, Fundamentals and Applications Wiley, New York, (2000) 341.

[88] E. R. Vago, E. J. Calvo, M. Stratmann, Electrochimica Acta 39 (1994) 1655.

[89] M. S. El-Deab, T. Ohaka, Electrochimica Acta 47 (2002) 4255.

[90] C. Janáky, B. Endrődi, O. Berkesi, C. Visy, Journal of Physical Chemistry C 114 (2010) 19338.

[91] A. Pailleret, N. T. L. Hien, D. T. M. Thanh, C. Deslouis, Journal of Solid State Electrochemistry 11 (2007) 1013.

[92] A. L. Andrade, D. M. Souza, M. C. Pereira, J. D. Fabris, R.Z.Domingues, Journal of Nanoscience and Nanotechnology 9 (2009) 3695. 


\section{Köszönetnyilvánítás}

Köszönet illeti Dr. Visy Csabát, Dr. Dékány Imrét és Dr. Erdőhelyi Andrást, a Fizikai Kémiai és Anyagtudományi Tanszék (2009-ig Fizikai Kémiai Tanszék) korábbi, és jelenlegi vezetőit, amiért lehetővé tették, hogy a doktori disszertációm megírásához szükséges munkámat a tanszékükön végezhessem.

Szeretnék köszönetet mondani témavezetőmnek, Dr. Visy Csaba egyetemi tanárnak, hogy munkám során szakmai ismeretekkel, tanácsokkal látott el, és nem utolsó sorban a vezetése alatt eltöltött időben nyújtott ösztönzésért, ami nagyban elősegítette a dolgozat elkészülését.

Köszönettel tartozom Lukács Zsófiának, hogy tudományos diákkörös hallgatóként csatlakozott a kutatási témához és tevékenyen részt vett benne.

Továbbá szeretném megköszönni a közvetlen munkatársaimnak: Peintler-Kriván Emesének, Janáky Csabának, Tóth Péter Sándornak, és Endrődi Balázsnak, hogy nem csak biztatásukkal, hanem a baráti légkör megteremtésével is hozzájárultak a munkám sikerességéhez.

Köszönöm †Dr. Patzkó Ágnes egyetemi adjunktusnak a röntgendiffrakciós vizsgálatok során nyújtott segítségét, az ELTE TTK Magkémiai Laboratóriumában dolgozó Németh Zoltán egyetemi adjunktusnak a Mössbauer-spektroszkópiás vizsgálat elvégzését és Jouko Kankare professzornak a lehetőséget, hogy az elektrokémiai kvarckristály-mikromérleg technikával történt méréseket a turkui egyetemen végezhettem el. Köszönöm továbbá Dr. Tombácz Etelka egyetemi tanárnak és kutatócsoportjának, hogy biztosították számomra a kísérletek során felhasznált magnetit nanorészecskéket.

Köszönöm családomnak, hogy megfelelő hátteret biztosítottak a tanulmányaim során. Végül köszönöm páromnak, Hajninak, hogy mindvégig bíztatott és hasznos észrevételeivel segítette a doktori értekezésem elkészítését. 